1975

\title{
Nietzsche's Philosophy of Play
}

Lawrence M. Hinman

Loyola University Chicago

Follow this and additional works at: https://ecommons.luc.edu/luc_diss

Part of the Philosophy Commons

\section{Recommended Citation}

Hinman, Lawrence M., "Nietzsche's Philosophy of Play" (1975). Dissertations. 1584.

https://ecommons.luc.edu/luc_diss/1584

This Dissertation is brought to you for free and open access by the Theses and Dissertations at Loyola eCommons. It has been accepted for inclusion in Dissertations by an authorized administrator of Loyola eCommons. For more information, please contact ecommons@luc.edu. (c) $($ ) $(9)$

This work is licensed under a Creative Commons Attribution-Noncommercial-No Derivative Works 3.0 License. Copyright @ 1975 Lawrence M. Hinman 


\section{NIETZSCHE'S PHILOSOPHY OF PLAY}

by

Lawrence M. Hinman

A Dissertation Submitted to the Faculty of the Graduate School of Loyola University of Chicago in Partial Fulfillment of the Requirements for the Degree of Doctor of Philosophy

June

1975 
ACKNOWLEDGMENTS

I wish to gratefully acknowledge the constructive criticism, encouragement, and patience shown by Professors Hans Seigfried, Edward A. Maziarz, Francis J. Catania, and Ingeborg Heidemann. Without their help, this dissertation could not have been written. Moreover, I would like to acknowledge the help provided by the Alfred J. Schmitt Foundation for their Dissertation Fellowship which enabled me to pursue my research in Germany. Fina1ly, a1though words are inadequate to do so, I wish to thank Pauline, whose very presence was a source of strength. 
VITA

The author, Lawrence Michael Hinman, is the son of Loren Donald Hinman and Ann (Murphy) Hinman. He was born on September 26, 1944, in Chicago, Illinois.

His elementary education was obtained in the Catholic schools of Chicago, Illinois, and secondary education at St. Ignatius High School, Chicago, Illinois, where he was graduated in 1962.

In September, 1962, he entered Loyola University of Chicago, and in June, 1966, received the degree of Bachelor of Science in Hunanities with a major in philosophy.

In September, 1966, he entered the graduate program in phi1osophy at Loyola University of Chicago. He finished his M.A. thesis on Jean-Paul Sartre in August, 1967, and received the degree of Master of Arts in February, 1968. He continued on in the Ph.D. program, successfully passing his candidacy examination in January, 1970, The following two years were spent at the University of Bonn, Federal Republic of Germany, doing research on his dissertation. For the second year of research, he was awarded an Arthur J. Schmitt Dissertation Fellowship. He successfully defended his dissertation in Chicago in August, 1973.

In September, 1973, he became a Visiting Assistant Professor of Philosophy at Loyola Marymount University, Los Angeles, California. 
TABLE OF CONTENTS

Page

ACKNOWLEDGEMENTS . . . . . . . . . . . . . . . . . ii

LIFE • • . . . . . . . . . . . . . . . . . . . . $\mathrm{.} i \mathrm{i}$

Chapter

I. INTRODUCTION . . . . . . . . . . . . . . . . . 1

II. PARADIGMATIC FORMS OF PLAY: THE DIONYSIAN, APOLLINIAN

AND TRAGIC ........................ 18

Introduction . . . . . . . . . . . . . . . 18

Apollinian and Dionysian Play . . . . . . . . . . 22

The Function of Art . . . . . . . . . . . . . . 25

Dionysian Play . . . . . . . . . . . . . . 26

Apollinian Play ................... . 38

The Contrast Between the Dionysian and Apollinian . . . . 43

The Tragic . . . . . . . . . . . . . . . 45

On the Adequacy of Play ............... 47

Conclusion................. 53

III. PLAY AS THE HIGHEST FORM OF HUMAN ACTIVITY . . . . . . . 55

Introduction . . . . . . . . . . . . . 55

A. The Ideal of Creative Play . . . . . . . . . 57

The Three Metamorphoses . . . . . . . . . 57

The Free Spirit . . . . . . . . . . . . 75

The Order of Rank . . . . . . . . . . . . . 86

Concluding Remarks on the Ideal of Creative Play . . . 97

B. Nihilism and the Necessity of Play . . . . . . . . 100

Introduction . . . . . . . . . . . . . . . 100

The Necessity of Nihilism . . . . . . . . . 101

The Meaning of Nihilism . . . . . . . . . . 103

Play and the Overcoming of Nihilism . . . . . . . 108

Conclusion . . . . . . . . . . . . . . . 114

IV. MORALITY AND THE WILL TO POWER . . . . . . . . . . . . 117

Introduction . . . . . . . . . . . . . . . . 117

A. Morality as a Game of Self-Deception . . . . . . 118

Morality as Interpretation . . . . . . . . . . 118 
The Instinctual Foundations of Morality . . . . . . 119

Morality as Negation ................. 121

Morality, Free Will and Purpose . . . . . . . . 123

Conclusion .................... . 125

B. The Will to Power . . . . . . . . . . . . 126

Willing and Creating............... . 126

The Will to Power . . . . . . . . . . . . . . 128

The Opposite of the Will to Power . . . . . . . 130

Conclusion . . . . . . . . . . . . . . 135

V. ON THE SELF, SELF-OVERCOMING AND THE OVERMAN . . . . . . . 137

Introduction . . . . . . . . . . . . . . . . . 137

The Ego as the Overcoming of the Herd . . . . . . . . . . 138

The Linguistic Basis of the Concept of the Ego . . . . . . . 139

The Concept of the Ego and the Belief in Causality . . . . . 141

Overcoming the "Ego-Feeling" . . . . . . . . . . . . . . 144

The Dependence of Intellect, Will and Sensation on Valuation 146

The Intellect and Thinking . . . . . . . . . . . . 147

Willing . . . . . . . . . . . . . . . 151

Evaluations ..................... . 154

On the Affects and the Will to Power . . . . . . . . . 157

On the Overman . . . . . . . . . . . . . . . . . 164

Conclusion . . . . . . . . . . . . . . . . . . 171

VI. THE ETERNAL RECURRENCE AND THE PLAY OF FORCES: TEMPORALITY

AND PLAY . . . . . . . . . . . . . . . . . . . . 173

Introduction . . . . . . . . . . . . . . . 173

A. The Framing of the Question of Temporality . . . . . . 177

Time Past: The "It Was" . . . . . . . . . . . . 177

Being and Becoming .. . . . . . . . . . . . . 178

Traditional Concepts of Time.... . . . . . . 181

Creative Willing of Time . . . . . . . . . . . 182

B. The Eterna1 Recurrence of the Same . . . . . . . . . . 184

Oblique References to the Eternal Recurrence . . . . . 185

The Law of the Eternal Recurrence of the Same . . . . . 192

The Relationship of the Eternal Recurrence and Power . . 196

The Primacy of Power and Force . . . . . . . . . 203

The Meaning of "the Same" . . . . . . . . . . . 204

The Thinking and Naming of the Eternal Recurrence . . . 211

The Willing of the Eternal Recurrence Through Power . . 215

Conclusion . . . . . . . . . . . . . . . . 217

c. Time and the Eternal Recurrence of the Same . . . . 220

The Nature of Time . . . . . . . . . . . . 221

D. Play and the Eternal Recurrence . . . . . . . . . . 224

The Play of the World: the Early Writings . . . . . . 226

The Play of the World: the Final Vision . . . . . . . 228 
CONCLUSION . . . . . . . . . . . . . . . . . . 233

BIBLIOGRAPHY . . . . . . . . . . . . . . . . . . 238

APPENDIX: LIST OF ABBREVIATIONS . . . . . . . . . . . . . . . 246 
CHAPTER I

INTRODUCTION

At times it is rather difficult in a dissertation to say things in a straightforward manner--without footnotes, without the numerous qualifications that inevitably come to mind for each sentence. It becomes especially difficult when, instead of advancing and defending a thesis, one attempts to express and explore the personal significance of an idea. Comments on such matters simply do not tend to fit into the structure of the dissertation. Thus in this Introduction I would like to discuss some of the problems involved in this dissertation, some of the issues which can be touched upon only in a peripheral manner in the body. of the work but which are, at least for me, highly significant.

Before doing that, it is nonetheless in order to introduce the main themes of the dissertation, for such an introduction will establish the context for the remarks which follow in this Introduction. I am basically concerned with two things in the dissertation. The first of these is to show, not only that Nietzsche does have a philosophy of play, but also that his philosophy is a philosophy of play. This involves an explication of the category of play in Nietzsche's philosophy and an interpretation of the main 
Lenets of his thought in terms of the category of play. In doing this, I have considered the writings centering around The Birth of Tragedy as a distinct group. In discussing the writings after that, specific topics have been approached thematically. In so doing, I am not implying that there is no significant development in Nietzsche's philosophy after the period of The Birth of Tragedy, but rather am confining any discussion of development to the framework of specific issues.

In addition to this, I have drawn freely upon Nietzsche's posthumous1y published manuscripts and notebooks. While it is certainly inappropriate to give them equal weight with the published works, they do in fact offer valuable insights into Nietzsche's own thinking and it would be inappropriate to ignore them. This is particularly true where they expand and deepen the positions presented in the works Nietzsche approved for publication. As a general guide to their use, I have tried to follow this principle: where they stand in direct conflict with his public position, they must be used with great caution; where the notebooks expand and deepen insight into positions found in the works he published, their use is entirely appropriate. However, this can serve only as a general principle in approaching the question. In specific instances, questions of context and interpretation arise and a judgment must be made in relation to that specific case. In ambiguous cases, it becomes necessary to draw attention to the difference between Nietzsche's published and his unpublished positions and to label them as such. 
In approaching the writings which center around The Birth of Tragedy, I have argued that these present themselves as a develoded philosophy of play, a coherent whole on the conceotual level. The category of play is the fundamental one in terms of which Nietzsche's other categories for understanding existence--the Dionysian, the Apollinian, and the tragic--are to be understood. The adequacy of this category of play is questioned, both in terms of its ontological background of the primordial contradiction and pain of existence and in terms of the social background of slavery which it presupposes. What is at stake here is the relationship between play and what one might call the real world--more specifically, the relationship between play and work, a topic to which $\mathrm{I}$ shall return in this Introduction.

Taking up the writings which follow the Birth of Tragedy and which constitute Nietzsche's developed philosophy, I have argued that his position leads him inevitably to a philosophy of human activity as play. This is evident in a positive sense when one examines "The Three Metamorphoses" in Thus Spoke Zarathustra, the notion of the free spirit, and the doctrine of the order of rank. In each of these cases some form of play becomes the highest activity for man. It is also true in a negative sense that Nietzsche is led inevitably to a philosophy of human activity as play. He destroys the conditions of the possibility of any type of meaningful human activity except play. The consideration of nihilism and the critique of morality give evidence of this, as does his analysis of the traditional notion of the 
self. Finally, a consideration of the concepts of the will to power and the overman conclude the investigation of human activity and provide in both cases a transition to the more fundamental type of play in Nietzsche's thought: the play of forces which constitutes the world as such.

The final chapter considers in detail the category of play on a cosmic level, showing the way in which the doctrine of the eternal recurrence of the same gives ultimate expression to this cosmic play of forces and serves as an integrating category within Nietzsche's vision of the universe.

My purpose here is not, however, merely to explicate Nietzsche's category of play, but also to offer a critique of it. This critique takes place on two levels. First, there is a critique of the internal consistency of his position. This includes, for example, questions about whether the emphasis on the individual is compatible with his critique of the self, whether the notion of the will to power is contradicted by the critique of the will, and whether the notion of the overman and that of the eternal recurrence are compatible. The main thrust of this internal criticism is to show that Nietzsche's own critical philosophy, if valid, is not so devastating as to call into question the very grounds of his own positive philosophy. The tension in Nietzsche's position between his critical thought and his positive philosophy can best be understood and resolved in terms of the category of play.

There is a second type of criticism present in the following 
chapters, one which centers specifically around the adequacy of the category of play itself as Nietzsche develops it. In this respect, my concern with Nietzsche is somewhat incidental to my interest in the category itself. Is this particular philosophy of play adequate? If not, what are its shortcomings? What would constitute an adequate philosophy of play? It is not my intention to try to provide a full --or even adequate--answer to this final question, but rather simply to raise the question itself and to explore some of its dimensions. To answer that question adequately would require yet another dissertation, hardly an enticing thought at this particular time; but in a sense, this dissertation is the first step toward such a second work in which an adequate philosophy of play can be developed.

Granting that it is impossible to develop such a philosophy of play in this dissertation, I would like to take the opportunity here to sketch some of the dimensions of such a philosophy. There are two reasons for doing so. First, these remarks may give the reader some hint about the presuppositions with which I approach this analysis of Nietzsche's philosophy. Second, I hope that they may be of sufficient interest to the reader to stimulate him or her to further thought on this subject.

The first difficulty one encounters here is arriving at a definition of play. I shall take the description given by Johan Huizinga as a point of departure, since in fact it was my own startingpoint several years ago when I began reflecting upon the problem of play. 
Summing up the formal characteristics of play we might call it a free activity standing quite consciously outside "ordinary" life as being "not serious," but at the same time absorbing the player utterly and intensely. It is an activity connected with no material interest, and no profit can be gained by it. It proceeds within its own boundaries of time and space according to fixed rules and in an orderly manner. It promotes the formation of social groupings which tend to surround themselves with secrecy and to stress their difference from the common world by disguise or other means. 1

While this tends to be a good working definition, problems with it do arise. These problems can be grouped into two categories: difficulties with the applicability of the specific characteristics and problems with the general category of play as such.

A number of problems falling into this first category can be enumerated here. First, in what sense is play a free activity? It is clear that one cannot be forced to play by some external power or authority, but is not play often so spontaneous as to be initiated without the player's thinking about it? Moreover, is this a characteristic which applies to play alone? Are we to understand that whatever is the opposite of play is an unfree activity? Second, is it necessary to presuppose a "real" world to which the world of play is juxtaposed? Would it be possible to conceive of existence merely as a multiplicity of play worlds, none of which has any ontological superiority over the others? If play does become connected with some material interest, does it cease to be play? Is the essential factor

1

Johan Huizinga, Homo Ludens. A Study of the Play-Element in Culture (Boston: Beacon Press, 1966), p. 13. 
the intent of the player, or is play to be defined in more objective terms? Is a child, for example, who is participating in play therapy really playing? While it is clear that play has its own spatial and temporal boundaries, is this not also the case for other activities? Does not work, for example, have its own special time and place? Does play always lead to the formation of social groupings, or may it not be a very individual activity? To what degree can it be said that the play world overflows into the non-play worlds, goes beyond its fixed boundaries and reshapes the world out of which it originally springs? To what extent is the reverse also true: to what degree does the non-play world actually permeate the world of play? To what extent is the world of play to be explained in terms of the contradictions and tensions of the non-play world?

While it is not possible to carry out this list of questions ád infinitum, it is clear that it could be extended substantially to show the numerous ambiguities in the concept of play. It has in fact been maintained that the concept of play is characterized by an ontological ambivalence that "means first of all that play eludes a univocal definition."2 Yet I find myself wondering whether the ambivalence one uncovers in the concept of play is attributable to the ontological ambivalence of play itself or to some other source. More specifically, I wonder if the ambivalence of the concept of play is not located in

${ }^{2}$ Ingeborg Heidemann, Der Begriff des Spieles und das aesthetische Weltbild in der Philosophie der Gegenwart (Berlin: Walter de Gruyter, 1968), p. 10. 
the specific contradictions of the contemporary experience of work. In an essay which I found to be rather thought-provoking, Helmuth Plessner suggested that the fact "that play in general has been made into a problem is something new and is connected with the development of industrial work." 3 Is it possible to go even further here and to suggest that the ambiguities and ambivalence one finds in the concept of play can be traced back to the corresponding ambiguities and contradictions in the contemporary experience of work? While I am not certain that each and every aspect of the ambiguity of the concept of play can be traced back to the experience of work within our society, this line of investigation appears to be a rather fruitful one.

Consider, for example, the following problem. Most play theorists would agree that play is a free activity. Schiller maintains this quite strongly when he argues that, "man plays only when he is in the full sense of the word a man, and he is only wholly man when he is playing." 4 Even if one does not want to go as far as Schiller has gone, it is quite difficult in most instances not to maintain that play is a pre-eminently free activity. This becomes problematic, however, when one recognizes another characteristic of

${ }^{3}$ Helmuth Plessner, "Spiel und Sport," Diesseits der Utopie (Düsseldorf: Diederichs, 1966), p. 160 .

${ }^{4}$ Friedrich Schiller, On the Aesthetic Education of Man in a Series of Letters, translated with an Introduction by Reginald Snell (New York: Frederick Ungar, 1965), p. 80. 
play. The separate time and place of play, the particular social groupings which grow up around it serve to underscore this point: the world of play is separate from that of everyday reality. Insofar as freedom is identified with the world of play, and insofar as play constitutes a world quite separate from everyday reality, then man's freedom is made ineffectual and the everyday world is absolved to that degree from the demand that it be made into a progressively freer world. Indeed, if one wanted to construct a world in which lip service was paid to the ideas of freedom and personal creativity, and yet in which at the same time such freedom and creativity could be controlled in a very practical way in order to prevent them from disturbing the social order, then one could hardly come up with a better idea than such a concept of play.

Another problematic aspect of play reveals itself when we consider this: many of the specific games we play tend to reinforce strongly the values of our own society. Sport offers a prime example of this. 5 It may do this in two ways. First, these values may be explicitly encouraged in the game: sportsmanship, honesty, competiveness, unquestioning acceptance of the rules, etc. Second, undesirable qualities may be relegated to the sphere of play, which then functions as a safety-valve for certain emotions. Aggression would be a prime example of this: one is supposed to let out one's aggressive tendencies in sports in order to avoid letting them manifest themselves

${ }^{5} \mathrm{Cf}$. Bero Rigauer, Sport und Arbeit. Soziologische Zusammenhaenge und ideologische Tmplikationen (Frankfurt am Main: Suhrkamp Verlag, 1969). 
in the everyday world. ${ }^{6}$ This seems to take place where the appearance of the unwanted emotion or trait is considered inevitable. Yet if this is to be the case, how then are we to understand the idea that play must be done for no material interest or profit? While the individual participating in the activity may not be directly motivated by such material interest or profit, the society in which the games take place clearly has a material interest in maintaining precisely those games which do tend to reinforce the values which it already holds and provide a safe outlet for undesirable emotions. This gives rise to a rather peculiar situation in which the individual's play, perhaps without his or her knowledge, may be used for ulterior purposes.

Thus play does have a very definite social function which includes, but is not exhausted by, the following aspects: giving the individual a realm of freedom and creativity outside of the everyday world, lessening the demands that the everyday world itself become freer and more creative, and inculcating in the players the values of the society in which they live, and providing a safe outlet for the expression of unwanted emotions.

One of the things I find most problematic about this situation is that freedom tends to become meaningless. Here I clearly presuppose that the world of everyday experience is of primary importance

${ }^{6}$ Cf. Konrad Lorenz, On Aggression (New York: Bantam Books, 1967), pp. $267 \mathrm{ff}$. for a suggestion of this nature. 
and that the immediate task before man is the improvement of that world. Given these two premises, I would maintain that the freedom which one discovers in the world of play is substantially a meaningless freedom for this reason: it cannot change the world of everyday experience, only temporarily suspend it. This becomes increasingly problematic as the amount of leisure time increases, for it puts a peculiar burden on man: not simply the burden of freedom, but the burden of meaningless or impotent freedom. Boredom arises, not simply where there is an excess of free time, but where the conditions of the possibility of using that free time in a meaningful manner are not present.

There is some evidence to suggest that the burden of increasing leisure time has already become a source of problems. The leisure time which one encounters upon retirement is often threatening, even to one's physical health. ${ }^{7}$ Long vacations, both for workers and students, are often difficult to cope with for the freedom which they present to the individual is a freedom which cannot change the world of their everyday experience in many cases.

The direction in which our economy is moving indicates that we are going to have an increasingly large amount of leisure time in the future: earlier retirement, longer vacations, shorter work weeks, later entry into the work force. In an increasingly technological

${ }^{7}$ Cf. Work in America. Report of a Special Task Force to the Secretary of Health, Education, and Welfare (Cambridge: The MIT Press, n.d.), pp. 77 ff. 
society, this movement seems inevitable for two reasons. First, it is simply impossible to keep the population busy producing as an everincreasing amount of goods can be produced for the same number of man hours. Second, it is necessary to give people more time to consume these goods, especially as production is turned increasingly toward luxury products. In this regard, leisure time must be converted into consumer time. Insofar as this does happen, leisure is clearly put in the service of consumption and such things as expensive vacations, hobbies requiring elaborate equipment, etc., proliferate.

The final problematic aspect of the category of play to which $I$ want to call attention here concerns the relation between play and needs. At times play is distinguished from work by suggesting that work is done in order to fulfill needs while play is only possible when one has gone beyond those needs. This position has some interesting implications, not the least of which is this: play is conceived against a background of forced labor. While it is possible to maintain that work is not forced by someone outside of the worker, but rather stems from the necessity imposed by his own needs, this distinction has little force within our own society. Today it is increasingly difficult to distinguish fundamental human needs (food, shelter, and clothing) from second level needs, the satisfaction of which has at times in our own society become as necessary as the satisfaction of fundamental human needs. There is clearly a distinction --the need for an automatic ice cube maker is not on the same level as the need for a minimal amount of nutrition each day. However, it 
is not inconceivable that the day will come when the need for automatic ice cube makers will be felt by some to be as strong as their need for nutrition. While it is then possible to maintain that the need for an automatic ice cube maker is a false need, one then introduces a distinction which is most difficult to maintain in light of the way in which people actually perceive their own needs.

Not only is it difficult to distinguish between primary and secondary needs, between true and false needs, but the problem is further complicated by the fact that the satisfaction of one need is usually a process which results in the creation of new needs. In this regard, Marx's thesis that "the creation of needs is the first historical act"8 is quite relevant. It suggests an interesting view of work as becoming progressively freer insofar as it goes beyond the givenness of fundamental needs and transforms needs themselves into human creations. In this case, the restrictions which man feels as stemming from his personal needs would in fact have their foundation in man's social and economic situation.

Thus the concept of need is problematic in two respects. First, the distinction between a real and a false need is rather difficult to draw and appears at best to be a relative one. Second, most needs are in a very real sense a human creation, in no way fixed or immutable in themselves but rather the product of human labor. It

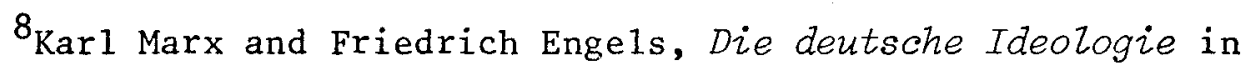
Werke, Volume III (Berlin: Dietz Verlag, 1969), p. 28. 
seems possible that play takes place when human needs have been satisfied only if one adopts a very narrow and non-dialectical notion of human needs, one which ignores the difficulties raised in the previous two paragraphs. Play is not beyond the realm of human needs. It is not at all unreasonable to suggest that we even have a need to play, remembering that such a need can be a human creation. Moreover, play itself can create new needs by exploring new dimensions of human activities which, when they are found satisfying, become an increasingly important and necessary part of human life. Thus play is related to needs in a two-fold sense: we create a human need to play, and in playing we create new needs.

Play, if it is to be understood fully, must be seen within the context of its societal dimensions, one aspect of which is its relation to needs. To treat play apart from its network of societal relations is to reify the phenomenon of play, to give it a false and independent meaning which it does not possess in the situation. As one begins to see play within this larger context, it becomes evident that, just as the contemporary situation is characterized by the experience of alienated labor, so too the notion of play that arises out of this situation is one of alienated play. More specifically, we find in play precisely those elements of human activity which are missing in alienated labor, but they are present in such a way that they offer only an unreal, apparent satisfaction. If the experience of work is characterized by lack of freedom, then play is a preeminently free activity; but the freedom one encounters in play is 
powerless to change the real world of everyday experience, If work is always done for a purpose, play is done for its own sake, purposeless but meaningful; but the created meaning of play is barred from the everyday world precisely because it is only a game. If work is done under the pressure of needs, then play takes place in a realm beyond those needs; but play is both the product of such needs and, in turn, helps produce new needs. Yet it cannot be admitted that it satisfies those needs fully, for that would then allow play to be on equal footing with every other aspect of everyday reality.

If one were to state this problem in terms that Marx develops in the economic and philosophical manuscripts of 1844 , it would be as follows. In alienated labor, man is separated from the product of his labor, from the activity itself, from his species being, and from his fellow men. 9 In alienated play, man is not separated from whatever product his play may incidentally produce, but such products are not given any real meaning or value in the everyday world because they are only play. If they do assume any much meaning or value, then it is as commodities, in which case the product is then an alienated one. In a similar way, the activity of play is a free one, but this freedom is confined precisely to that which is unimportant, which does not change the course of history or alter the everyday world. While I do not find it particularly fruitful to approach this problem

${ }^{9}$ Cf. Karl Marx, "Ökonomisch-philosophische Manuskripte (1844)," in Karl Marx and Friedrich Engels, Werke, Supplementary Volume, Part One (Berlin: Dietz Verlag, 1968), pp. 510-22. 
in terms of the concept of species-being, it could be argued that if species-being involves active production in the objective world (it involves much more than this in these manuscripts), then the activity of play could allow such active production, but it would not be such that it could enter into the objective world for the same reasons given for the alienated character of the activity of playing. Finally, play does promote the rise of free associations among men, but again these associations are restricted to the unreal world of play and do not, properly speaking, involve themselves in the affairs of the everyday world except insofar as this is necessary to prepare for the game. I hope that these remarks will give the reader some idea of some of the problems and contradictions which I find in the idea of play and why I think that the generally accepted notion of play is actually one of alienated play. It has not been my purpose here to offer in any sense a complete argument on this topic, but rather to explore the questions themselves and to present the direction in which I think the answers are to be found. I suspect that, under what one might call ideal conditions, work and play would merge into a single activity. Since there appears to be no immediate danger that such ideal conditions will force themselves on us on a general level in the immediate future, it is perhaps in order to conclude with a few. words in defense of play.

The main thrust of my criticism in the previous pages has been against an idea of play in which play is separate from the everyday world, in which there is, at least on the conceptual level, little or 
no interaction between the play world and the non-play worlds. While there is considerable justification in the literature on play theory for looking at play in this way, this position does not exhaust the possibilities. That it is, however, a position which $I$ think is inadequate and with which I want to take exception should be abundantly clear by this point. An alternative approach to the problem of play seems to offer much more promise: by recognizing the continual dialectical interaction between work and play, one can view play as the leading edge of human activity, continually going beyond the givenness of the situation in order to give it an openness, a wealth of possibilities, which it might not otherwise possess. In this context, work and play do not represent two different worlds, but rather two aspects or directions of the same world, each of which would be substantially diminished without the other. Whereas play without work to concretize it would be trivial freedom, work without play would be equally alienated, uncreative and forced. Perhaps such a relationship would eventua11y lead to a situation in which the conditions of the possibility of a true union" of work and play would arise. 
CHAPTER II

\author{
PARADIGMATIC FORMS OF PLAY: \\ THE DIONYSIAN, APOLLINIAN, AND TRAGIC
}

\title{
Introduction
}

Although Nietzsche's main concern in The Birth of Tragedy and the writings which form preliminary studies for it ${ }^{1}$ was to mark out the way "through the labyrinth, as we must call it, of the origin of Greek tragedy," 2 the significance of these works is not limited to this topic alone. In a preface added in 1886, Nietzsche draws attention to one of the main problems which, in retrospect, he saw

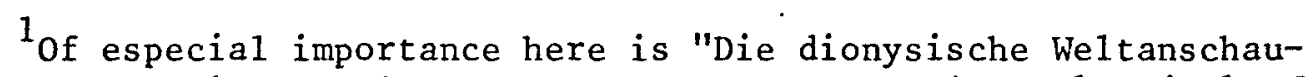
ung," part of which are incorporated word for word into The Birth of Tragedy, and a revision of this same piece from June, 1870, "Die Geburt des tragischen Gedankens." These are to be found in Nietzsche Werke, Kritische Gesamtausgabe, edited by Giorgio Colli and Mazzino Montinari, Dritte Abteilung, Zweiter Band (Berlin: Walter de Gruyter, 1973), pp. 43-69, 71-91.

Hereafter, all references to the Colli and Montinati edition of Nietzsche's works will be given with the title of the individual work (or an abbreviation of it) first, followed by the part number, then the volume number within that part, and finally the page number. Thus: "Die dionysische Weltanschauung," III/2, pp. 43-69. A full 1ist of abbreviations is to be found in the Appendix.

${ }^{2}$ Die Geburt der Tragödie, $\$ 7$, III/1, p. $48=$ The Birth of Tragedy, in The Birth of Tragedy and The Case of Wagner, translated by Walter Kaufmann (New York: Random House, 1967), p. 56. Hereafter, Die Geburt der Tragödie will be abbreviated as GT and its English translation as BT. 
himself as confronting: the problematic character of science itself. ${ }^{3}$ Indeed, when The Birth of Tragedy is seen in retrospect, ${ }^{4}$ many of the major themes of Nietzsche's later philosophy can be found to be present, especially if one concentrates upon the symbolism of the Apollinian and the Dionysian. ${ }^{5}$ The investigation of the origins of Greek tragedy becomes the occasion for an inquiry, not only into the nature of tragedy itself, but also into fundamental questions about the nature and function of art, and in particular about the way in which art provides a means for confronting and going beyond the primordial pain of existence.

In the course of his investigation Nietzsche develops, albeit only implicitly at times, a notion of artistic activity as play. In so doing, he introduces a theme which recurs throughout his writings

\section{${ }^{3}$ GT, "Versuch einer Selbstkritik," 2; III/1, pp. 7 f. $=\mathrm{BT}$,} "Attempt at a Self-Criticism," 2, pp. $18 \mathrm{f}$.

4 For a collection of essays written without the benefit of such retrospective distance, see Der Streit um Nietzsches "Geburt der Tragödie", edited by Karlfried Gründer (Hildesheim: Georg 0lms Verlagsbuchhandlung, 1969). This contains reviews by E. Rohde, R. Wagner, and U. v. Wilamowitz-Möllendorff.

${ }^{5}$ Jean Granier, in Le problème de la Vérité dans la philosophie de Nietzsche (Paris: Editions du Seuil, 1966), p. 539, maintains this thesis: "Nous allon montret, en effet, que toute l'ontologie nietzschéenne se trouve déjà envelopée dans le noyau symbolique qui est 1'âme de son premier ouvrage la Naissance de la Tragédie, et que les progrès spéculatifs de Nietzsche n'ont fait que sanctionner 1 'appropiation de la substance spirituelle qui était déposée dans la symbolisme de 1'apollinien et du dionysien." Granier is concerned with showing that the comprehension of the duplicity of being as the play of art and truth is at the heart of Nietzsche's view of the world and that this comprehension is symbolized later in the figure of Dionysus and explicated in the notion of the will to power. 
in a most elusive manner: the category of play. Present in some of the most crucial passages he has written--indeed, as I shall show below, at the heart of his description of human existence and of the world itself--the concept itself remains unanalyzed. The elusiveness of the category of play, not only in Nietzsche's writings but also in itself, 6 makes analysis and interpretation especially difficult.

The Birth of Tragedy and the related writings from this period present a good example of this elusiveness. The word "play" is used infrequently in the final text, 7 but in "The Dionysian Worldview," an earlier formulation of the initial chapters of The Birth of Tragedy, it is a key concept for the understanding of both the Dionysian and the Apollinian worldviews. However, even where the word is used frequently, an explicit analysis of its meaning is lacking.

${ }^{6}$ In the section of her book dealing with the ontological definition of play, Ingeborg Heidemann has commented on the fundamental ambivalence of the concept of play:

Die ontologische Ambivalenz bedeutet zunächst, daß das Spiel sich einer eindeutigen Bestimmung entzieht. . . Es scheint etwas zu sein und nicht zu sein im selben Aspekt; es ist real und es ist nicht real; es ist in der Welt und es ist nicht in der Welt. Seine Seinsweise ist die eines Unbestimnt-Bestimnten. Der Begriff des Spieles und das ästhetische Weltbild in der Philosophie der Gegenwart (Berlin: Walter de Gruyter, 1968), 10. The ambivalence of the category of play in Nietzsche's philosophy will be considered below.

7Explicit use of the word "play" ("Spiel") in The Birth of Tragedy itself is to be found only in Chapters 23, 24, and 25. At times, "Spiel" is translated as "game" in the Kaufmann translation. 
In this chapter, I shall elucidate the meaning of the category of play and show the way in which this category is central to Nietzsche's understanding of artistic activity and of existence itself insofar as these questions are considered in The Birth of Tragedy and the related writings. In particular, it will be shown that there are five distinct senses in which the word "play" is used in these writings: (1) dreaming as a way of playing with the real, (2) the artistic activity of playing with the dream, (3) intoxication as nature playing with the person, (4) the artistic activity of playing with intoxication, and (5) the interplay of the Dionysian and Apollinian forces in the world as constitutive of tragedy. The first two senses of play are Dionysian, and the second two are Apollinian.

These paradigms are significant, not only in that they show that the category of play was present in Nietzsche's thought even at this early date, but also because they offer a way of distinguishing among the various meanings of play, distinctions which become rather blurred in his later works. In addition to this, a consideration of Nietzsche's category of play in relation to his view of the Greek state gives us an insight into a fundamental problem in Nietzsche's philosophy: the relationship between play and work, creativity and need, freedom and slavery. In this regard, I shall show that the category of play is central to the three main categories (the Appollinian, the Dionysian, and the tragic) in terms of which Nietzsche understands existence, and that this category of play is conceived against a background of work as slavery. As a result of this 
dichotomy between creative play and work as slavery, the category of play in Nietzsche's early writings is, as will be shown below, fundamentally one of alienated play. Apolzinian and Dionysian Play

In "The Dionysian Worldview" Nietzsche distinguishes between the Apollinian and the Dionysian by presenting them as two different types of play. The art of the Apollinian artist, the creator, is playing with the dream, and the dream itself is to be understood as the game or play of the individual man with the real. ${ }^{8}$ The creativity of the Dionysian artist, on the other hand, is to be found in playing with intoxication, intoxication itself being a game which nature plays with man. ${ }^{9}$ Thus there is a double sense of play within both the Apollinian and the Dionysian. This can be represented schematically as follows.

immediate manifestation

Dionysian

Apolzinian intoxication: the game that nature plays with man

the dream: the game that the individual man plays with the real artistic form

playing with intoxication

playing with the real

8"Die dionysische Weltanschauung," 1; III/2, p. 46. "Während also der Traum das Spiel des einzelnen Menschen mit dem Wirklichen ist, ist die Kunst des Bildners (im weiteren Sinne) das Spiel mit dem Traum."

${ }^{9}$ Ibid., p. 47. "Wenn nun der Rausch das Spiel der Natur mit dem Menschen ist, so ist das Schaffen des dionysischen Künstlers das Spiel mit dem Rausche." Cf. "Die Geburt des tragischen Gedankens," ibid., p. 74: "Die dionysische Kunst dagegen beruht auf dem Spiel mit dem Rausche, mit der Verzüchung." 
The four basic senses of play follow from this. The Apollinian artist plays with the dream, and the dream itself is a way of playing with the real; the Dionysian artist plays with intoxication, but the intoxication is nature playing with him.

Central to this distinction is the idea of the player. In both the Apollinian and Dionysian forms of play, the player has more control of the game in its artistic form. Moreover, the Apollinian player is more clearly in control of the game that he plays than is the Dionysian player. Indeed, the difference seems to be fundamental, for in the Dionysian experience, "the man is no longer artist, he has become the work of art,"10 for the artistic power of nature itself is manifesting itself in the Dionysian artist. "This man, shaped by the artist Dionysus, is related to nature as the statue is to the Appollinian artist."11 In this sense, it is more accurate to say that the Dionysian artist, rather than playing with nature, is played with by nature. While both the Apollinian and the Dionysian stem from nature, their relation to nature differs: the former being active, the latter being passive. However, even this formulation is somewhat misleading in regard to the status of the Dionysian artist. Nietzsche likens

10"Die dionysische Weltanschauung," 1 ; III/2, p. $47=$ GT, 1; III/1, p. 26 = BT, 1, p. 37: "Der Mensch ist nicht mehr Künstler, er ist Kunstwerk geworden."

11"Die dionysische Weltanschauung," 1; III/2, p. 47: "Dieser vom Künstler geformte Mensch verhält sich zur Natur, wie die Statue zum apollinischen Künstler." 
his position to that of a person who is dreaming and yet realizes that he is dreaming: ". . . so must the disciple of Dionysus be intoxicated and at the same time lurk behind himself as an observer."12 If this description does not entirely clarify the position of the Dionysian artist, it at least shows the ambiguity of his position and the need for clarification. This same ambiguity occurs in Nietzsche's description of the child playing and in his notion of the self and constitutes a fundamental tension at the heart of his category of play and his idea of man.

The ambiguity one encounters in the notion of the Dionysian player goes beyond its specifically Dionysian character. It is rooted in the very nature of being a player, in the ambivalent role the player has. Jürgen Moltmann has described this we11.

The creative playing of men is always a playing with something which, in turn, plays with the player. Man plays with the waves of the ocean and they play with him. He plays with colors, sounds, and words and also becomes their playmate. He speaks and responds, is active and passive, giving and receiving at once. Playing he is neither master nor servant. This is true not only for games in life but also for the game of life.13

The difficulties encountered in determining the precise relationship between the Apollinian or Dionysian player and that with which he plays stem in part from the fundamental ambivalence of the relation

12Ibid.: "So muß der Dionysosdiener im Rausche sein und zugleich hinter sich als Beobachter auf der Lauer liegen."

13Jürgen Moltmann, Theology of Play, translated by Reinhard U1tich (New York: Harper and Row, 1972), p. 24. 
which exists between player and plaything: to be a player involves being a plaything at the same time.

The Function of Art

Before turning to a more detailed consideration of Dionysian and Apollinian play, it is necessary to see clearly why they came into existence. The background, against which both the Apollinian and the Dionysian are set in The Birth of Tragedy, is the folk wisdom of Silenus, the companion of Dionysus. Asked by King Midas what man's greatest good is, he replied: "What is best of all is utterly beyond your reach: not to be born, not to be, to be nothing. But the second best for you is--to die soon."14 Existence itself is characterized by horror and terror, by the primordial pain which gives rise to individuation. Silenus's wisdom gives this aspect of existence its highest expression. In order to be able to live at all, in order to overcome the terror and pain of existence at least to a limited degree, the Greeks created their gods and their art. Art makes life possible by seducing man to live on through illusion. In this sense, art is a game, a form of playing, which makes it possible to live on despite the fundamental pain and terror of existence.

${ }^{14} \mathrm{GT}, 3$; III/1, p. $31=\mathrm{BT}, 3, \mathrm{p} .42:$ "Das Allerbeste ist für dich gänzlich unerreichbar: nicht geboren zu sein, nicht zu sein, nichts zu sein. Das Zweitbeste aber ist für dich--bald zu sterben." A1so see, "Die dionysische Weltanschauung," 2; III/2, p. 52 . 
There are two fundamentally different ways in which the game of art can be played out: the Dionysian and the Apollinian ways. Both involve the creation of illusion: the Dionysian illusion is that of oneness with all of nature and man, while the Apollinian illusion creates individuation, proportion, harmony in measure and balance. Apollinian art covers up the primordial pain of existence, but that pain remains in the background. Dionysian art covers up the individual, but he continues to lurk behind himself.

The basic premise, upon which Nietzsche's view of existence is founded in these writings, is that existence is at its very heart contradictory, a primordial pain. The concept of play is presented as a way of coming to grips with this primordial contradiction and pain. The question which must now be considered is this: in what way, and to what degree, does each of these types of play succeed in overcoming this primordial pain and contradiction? The meaningfulness and validity of the category of play within Nietzsche's early philosophy depend upon the degree to which it can effectively deal with this challenge. In the following sections, it will be shown to what extent both Apol1inian and Dionysian play are caparable of this and the degree to which it is possible at all within Nietzsche's early framework.

Dionysian Play

It is necessary, at this point, to make two distinctions in relation to the notion of the Dionysian in order to clarify the various sense in which Nietzsche uses this word. First, the Dionysian 
may be considered as either a power of nature or as art; in both senses it may be called play, but in the latter case in a double sense. As a power of nature, the Dionysian is nature playing with man in intoxication. Dionysian art is playing with this intoxication, that is, playing with the game which nature is playing with man. Second, the Dionysian may appear either in its pure form (of which the titanic-barbaric may be taken as an example) or in a mediated form, in which case the Dionysian exists in relation to the ApolIinian (usually in a struggle against it, but in the case of Attic tragedy in union with it). Although there is a common element which unifies these pairs, the differences are significant enough to change the understanding of play in each instance.

The Dionysias as a natural force manifests itself "either under the influence of the narcotic draught.. . or with the potent coming of spring that penetrates all nature with joy."15 The Bacchic choruses of the Greeks and the dancers of St. John and St. Vitus are examples of the Dionysian manifesting itself as a natural force. They are characterized by the dissolution of everything subjective, a total eclipse of the self, an overcoming of the principle of individuation which leads to a becoming one, not only with one's fellow men, but also with nature. In such instances, the Dionysian arises

${ }^{15} \mathrm{GT}, 1$; III/1, pp. 24-25 = BT, 1, p. 36: "Entweder durch den Einfluss des narkotischen Getränkes . . . oder bei dem gewaltigen, die ganze Natur lustvoll durchdringenden Nahen des Frühlings . . ." 
out of nature itself without the mediation of the artist. It is a "kinstlexische" force, 16 force, not in the technical sense of an "artistic" force, but in the wider sense of a formative force of nature. By calling the Dionysian a "natural force" and contrasting it to "art," I do not wish to deny the formative character of this force, but am rather reserving the term "art" to those instances where the mediation of the artist is a significant factor.

In addition to the feeling of intoxication which leads to self-oblivion and a oneness with other men and nature, the Dionysian consciousness is also characterized by doubts which arise about the rational character of experience, both in regard to its validity and in regard to its value. There are two major aspects to this doubt. First, the principles of causation and sufficient reason appear to admit of exceptions, and one consequently feels a certain awe--a mixture of attraction and repulsion--at the unfolding of a new world, a world no longer completely bound down by the categories of reason. Second, this consciousness involves a feeling of glorious transport which stems from the shattering of the principle of individuation. 17 The two are related: the principle of sufficient

${ }^{16} \mathrm{GT}, 2$; III/1, p. $26=\mathrm{BT}, 2, \mathrm{p} .38$. It should be noted that both the Apollinian and the Dionysian are regarded as "künstlerische Mächte," but I am concerned here only with the Dionysian.

17 GT, 1; III/1, p. $24=$ BT, 1, p. 36. Although Nietzsche takes Schopenhauer's position as a starting-point here, he is clearly presenting his own position as such on the Dionysian. 
allows the world of appearances to be ordered in a causal manner, thus establishing individual entities as separate from each other; the principle of causation allows the flux of existence to be stabilized in order to create independent entities. Once they begin to admit of exceptions, the experienced world is so radically transformed that it is, quite literally, a new world which unfolds in the Dionysian consciousness.

The Dionysian experience has another side to it which has not been considered yet. Aspects of this side include horribleness, ugliness, pain, cruelty, destructiveness and sensuality. There are two ways in which these characteristics can be attributed to the Dionysian. First, when one takes a standpoint outside of the Dionysian framework (for example, the Apollinian standpoint), these characteristics almost follow by definition. If the principle of individuation is central to one's vision of the world, the shattering of that principle will be a cause of suffering. If harmony and balance are the measure of beauty, then the primordial oneness and flux of existence, which the Dionysian seeks to uncover or create, will be considered ugly and horrible because they negate that harmony. A11 of these aspects of the Dionysian experience will be considered, at least in an implicit sense, to be destructive insofar as one looks at them from a non-Dionysian standpoint, since they are the negation of such standpoints.

There is a second way in which these qualities become an issue. Nietzsche distinguishes between the barbaric and the Greek 
forms of the Dionysian. The former is characterized by a complete sexual promiscuity which overrides tribal 1 aw and by the unleashing of "the most savage natural instincts . . . including even that horrible mixture of sensuality and cruelty which has always seemed to me to be the real 'witches' brew'."18 This kind of sensuality and cruelty is overcome in the Greek manifestation of the Dionysian, for its exposure to the Apollinian influence transforms and tames it. The Greeks created the Apollinian vision in order to survive, and for the Dionysian to survive in its struggle with the Apollinian it had to transform itself. It changes from intoxication as the game that nature plays with man into man's playing with intoxication. When this happens, there is a fundamental change in the role of the player: while in the barbaric Dionysian the player seems to be completely the plaything of nature, in the Greek Dionysian the player assumes a more ambiguous role, simultaneously throwing himself into the game and yet with a part of himself lurking behind, observing. Two factors are at play here in the transformation of the Dionysian from its barbaric form into the Hellenic one. First, there is the external threat of the Apollinian, which threatens to completely overcome the Dionysian. Second, there is an internal force which is at work here: the barbaric Dionysian consciousness,

${ }^{18}{ }_{\mathrm{GT}}, 2$; III/1, p. $28=\mathrm{BT}, 2$, p. 39: ". . . gerade die wildesten Bestien der Natur wurden hier entfesselt, bis zu jener abscheulichen Mischung von Wollust und Grausamkeit, die mir immer als der eigentliche 'Hexentrank' erschienen ist." 
left to itself, is completely self-destructive. For it to exist in its pure form would lead, eventually, to its own negation; in order to maintain itself, it has to go beyond itself. The interplay of these two factors, the Greek need to create the Apollinian in order to survive and the internal contradiction of the Dionysian that leads to its own destruction, leads to the transformation of the barbaric Dionysian into its Greek, artistic form.

This transfigured form of the Dionysian is usually encountered in Greek culture in the form of the Dionysian artist, the one who plays with intoxication rather than the one who lets it completely overcome him. The portrait of Archilochus in The Birth of Tragedy gives a clear picture of Nietzsche's conception of the Dionysian artist in Pre-Socratic times. ${ }^{19}$ The definition of the Dionysian genius, given from the notebooks of this period, is parallel to the published formulations, but somewhat more precise. The Dionysian genius is,". . . the man who, in complete self-oblivion, has become one with the primordial ground of the world, who now creates out of the primordial pain the reflection of it for his redemption . . ."20

${ }^{19} \mathrm{Cf}$. GT, 5-6; III/1, pp. 38-48 :: BT, 5-6, pp. 48-56.

$2 \mathrm{O}_{\text {This }}$ passage is to be found in the posthumously published notebooks from the time of GT in Friedrich Nietzsche, Die Geburt der Tragodie. Der griechische Staat, Kröners Taschenausgabe Band 70, mit einem Nachwort von Alfred Baeumler (Stuttgart: Alfred Kröner Verlag, 1964), pp. 206-07. 
It is in the creation of a reflection of this primordial pain that distance is to be achieved and, with that distance, the possibility of delivering oneself up from the experience, redeeming oneself. The Dionysian artist, in contrast to the Apollinian, is characterized by this forgetting of self: he gives himself over completely to the fundamental contradictions in existence, in order thereby to give expression to them. He himself becomes a mirror. Moreover, the nature of that which he is reflecting leads to a preference in regard to the way in which he communicates this vision: not in the analytic fashion to which language almost inevitably leads, but rather in lyric poetry and music.

Music is an especially appropriate mode of expression for the Dionysian artist because it is the language of the will, "an immediate copy of the will itself." 21 As such, it gives a meaningfulness to comparisons which could not otherwise be achieved. While it is certainly the case that music is not in each and every case necessarily Dionysian, ${ }^{22}$ it remains clear that music is a distinctive

${ }^{21} \mathrm{GT}, 16$; III/1, p. $100=\mathrm{BT}, 16, \mathrm{p} .100:$ ". . unmittelbar Abbild des Willens selbst ..."

${ }^{22}$ Arthur Danto has suggested this in his Nietzsche as Phirosopher (New York: The Macmillan Company, 1965), p. 50: ". . . music, after all, originally had Apollo as its patron diety; and Nietzsche recognized a kind of Apollinian music--'a rhythm of waves beating the shore, a plastic art'." (The quotation is from GT, 2; III/1, p. $29=$ BT, 2, p. 40.) Mozart's description of a musical experience, in which he could hear an entire work at one time rather than in a succession of moments, seems much closer to an Apollinian experience of music than a Dionysian one. Cf. Martin Heidegger, Der Satz vom Grund (Pfullingen: Verlag Günter Neske, 1957), pp. $177 \mathrm{ff}$. , for the quotation of Mozart's letter and Heidegger's interpretation of it. 
mode of expression for Nietzsche. It is not susceptible to categorization and manipulation in the same way that language is. Moreover, in the phenomenon of musical dissonance one encounters the best mirror of the ugliness and pain of existence. In discussing the way in which existence and the world are justified only as an aesthetic phenomenon, as a game which the will plays with itself, Nietzsche argues:

In this sense, it is precisely the tragic myth that has to convince us that even the ugly and disharmonic are part of the artistic game which the will in the eternal amplitude of $i$ ts pleasure plays with itself. But this primordial phenomenon of Dionysian art is difficult to grasp, and there is only one direct way to make it intelligible and grasp it immediately: through the wonderful significance of musical dissonance. 23

It is to this experience that the Dionysian artist brings the 1 is tener: the joyful realization that existence in its totality, even its ugliness and disharmony, is but a game or a play which the will plays with itself. It is through his play that he leads his audience and fellow participants to the basic play of forces which constitutes existence and through it he justifies this play by his creative act of joyful affirmation.

Yet how adequate is this justification? It seems to be problematic in at least two ways. First, the Dionysian state of this

${ }^{23} \mathrm{GT}, 24$; III/1, p. $148=\mathrm{BT}, 24$, p. 141: ". . . in welchem Sinne uns gerade der tragische Mythus zu überzeugen hat, dass selbst das Hässliche und Disharmonische ein künstlerisches Spiel ist, welches der Wille, in der ewigen Fülle seiner Lust, mit sich selbst spielt. Dieses schwer zu fassende Urphänomen der dionysischey Kunst wird

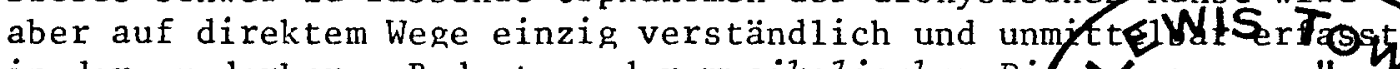
in der wunderbaren Bedeutung der musikalischen Dipsolanz 
intoxication is almost by definition a transitory state. This transitory quality becomes apparent in Nietzsche's description of Dionysian rapture.

For the rapture of the Dionysian state with its annihilation of the ordinary bounds and limits of existence contains, while it lasts, a lethargic element in which all personal experiences of the past become immersed. This chasm of oblivion separates the worlds of everyday reality and of Dionysian reality. But as soon as this everyday reality re-enters consciousness, it is experienced as such, with nausea: 2 an ascetic, will-negating mood is the fruit of these states. 2

Insofar as the Dionysian is necessarily a transitory state, it is impossible for Dionysian play to provide an adequate answer to the challenge posed by the primordial contradiction of existence. While this type of play can offer a few moments of respite, it is in itself inadequate. Dionysian play will always be bounded by the world of everyday reality; while it is capable of suspending that reality, it can never finally eliminate it.

${ }^{24} \mathrm{GT}, 7$; III/1, p. 52 = BT, 7, pp. 59-60. "Die Verzückung des dionysischen Zustandes mit seiner Vernichtung der gewöhnlichen Schranken und Grenzen des Daseins enthält nämlich während seiner Dauer ein lethargisches Element, in das sich alles persönlich in der Vergangenheit Erlebte eintaucht. So scheidet sich durch diese Kluft der Vergessenheit die Welt der alltäglichen und der dionysischen Wirklichkeit von einander ab. Sobald aber jene alltägliche Wirklichkeit wieder ins Bewusstsein tritt, wird sie mit Ekel als solche empfunden; eine asketische, willenverneinde stimmung ist die Frucht jener Zustände." Hans M. Wolff, in his Friedrich Nietzsche. Der Weg zum Nichts (Bern: Franke Verlag, 1956), p. 51, argues on the basis of this passage that it is no longer possible to speak of Dionysian life or Dionysian humanity, ". . . denn da sich die Ekstase als zeitlich beschränkt erweist, kann nur noch von 'dionysischen Zuständen' die Rede sein, denen der Zustand der Ernüchterung als der Normalzustand gegenübersteht." 
The second problematic aspect of Dionysian play is based on this: the truth which it uncovers is unbearable. In the paragraph following the one quoted above, Nietzsche develops this theme with great power.

In this sense, the Dionysian man resembles Hamlet: both have once looked truly into the essence of things, they have gained knowledge, and nausea inhibits action; for their action could not change anything in the eternal nature of things; they feel it to be ridiculous or humiliating that they should be asked to set right a world that is out of joint. Knowledge kills action; action requires the veils of illusion... true knowledge, an insight into the horrible truth, outweighs any motive for action, both in Hamlet and in the Dionysian man. 25

This, then, is the second factor which prevents Dionysian play from being an adequate answer in itself to the challenge posed by the primordial contradiction of existence. Truth is horrible, and the knowledge gained through the Dionysian experience kills action. The questioning of the value of knowledge is a theme which is found, not only in The Birth of Tragedy, but also in Nietzsche's notebooks from this period. 26 It is quite clear that knowledge of the fundamental

${ }^{25} \mathrm{GT}, 7$; III/1, pp. 52-53 = BT, 7, p. 60. "In diesem Sinne hat der dionysische Mensch Aehnlichkeit mit Hamlet: beide haben einmal einen wahren Blick in das Wesen der Dinge gethan, sie haben erkannt, und es ekelt sie zu handeln; denn ihre Handlung kann nichts am ewigen Wesen der Dinge ändern, sie empfinden es als lächerlich oder schmachvoll, dass ihnen zugemuthet wird, die We1t, die aus den Fugen ist, wieder einzurichten. Die Erkenntniss tödtet das Handeln, zum Handeln gehört das Umschleiertsein durch die Illusion .. . die wahre Erkenntniss, der Einblick in die grauenhafte Wahrheit überwiegt jedes zum Handeln antreibende Motiv, bei Hamlet sowoh1 als bei dem dionysischen Menschen."

${ }^{26} \mathrm{Cf}$. Karl Schlechta and Anni Anders, Friedrich Nietzsche. Von den vorborgenen Anfängen seines Philosophierens (Stuttgart-Bad Cannstatt: Friedrich Frommann Verlag, 1962), esp. pp. 99-117. 
essence of things is unbearable; indeed, the goal of knowledge seems to be the destruction of the world. ${ }^{27}$

These two factors, the transitory character of the Dionysian state and the unbearable quality of the truth which it uncovers, apply clearly to the Dionysian as such, but Nietzsche does not seem to find them applicable to Dionysian art in the passages cited above. When the Hellene has seen the horrible truth of existence, "art saves him, and through art--1ife."28 Art has a healing function, transforming the nauseating thoughts about the horror or absurdity of existence into notions that one can 1 ive with:

- . these are the sublime as the artistic taming of the horrible, and the comic as the artistic discharge of the nausea of absurdity. The satyr chorus of the dithyramb is the saving deed of Greek art; faced with the intermediary world of these Dionysian companions, the feelings described here exhausted themselves. 29

27 This view is developed, for example, in the forword to an unwritten book on the pathos of truth, "Fünf Vorreden. Ueber das Pathos der Wahrheit," III/2, p. 254: "Die Kunst ist mächtiger als die Erkenntni $\beta$, denn sie will das Leben, und jene erreicht als letztes Ziel nur--die Vernichtung.--" Also see Friedrich Nietzsche, Nachgelassene Werke aus den Jahren 1869-1872, in Nietzsche's Werke, Volume IX (Leipzig: Neumann, 1903), p. 72: "Der Zweck der Wissenschaft ist Weltvernichtung."

${ }^{28}$ GT, 7: III/1. D. $52=$ BT. 7. D. 59: "Ihn rettet die Kunst. und durch die Kunst rettet ihn sich--das Leben."

${ }^{29}$ GT. 7: III/1. D. $53=$ BT. 7 , p. 60 . ". . . diese sind das Erhabene als die künstlerische Bändigung des Entsetzlichen und das Komische als die künstlerische Entladung vom Ekel des Absurden. Der Satyrchor des Dithyrambus ist die rettende That der griechischen Kunst; an der Mittelwe1t dieser dionysischen Begleiter erschöpften sich jene vorhin beschreiben Anwandlungen." 
The transitory character of the Dionysian is overcome to some degree in Dionysian art in this respect: by exhausting the feelings which are aroused in the Dionysian experience, Dionysian art extends its effect temporally until that point where those feelings begin to build up again. Yet, even given this qualification, it seems that Dionysian art remains temporally limited. It can suspend time in the everyday world, but it cannot completely overcome it.

Dionysian art also makes the previously unbearable thoughts of the Dionysian experience into something bearable by justifying existence as an aesthetic experience, as a game the will plays with itself. Here the sense of self-oblivion characteristic of Dionysian play seems most important: the joyful affirmation of existence in its contradiction and pain is only possible when one completely forgets oneself. But this self-oblivion is also bv its very structure temporal1v limited: it can be extended for a while. but it seems imDossible to live for a long period of time in this state.

The Dionysian is, then, a particular type of play characterized by intoxication which leads to self-oblivion, an overcoming of the principle of individuation, a denial of the rational character of existence, and a creation of unity between man and man as well as between man and nature. In its initial form it is characterized by cruelty and destructiveness which is transformed into a joyful affirmation by Dionysian art. Yet as a type of play the Dionysian retains certain limitations, especially a temporal finitude which prevents it from completely overcoming the challenge posed to it 
by the pain and contradiction of primordial existence. Indeed, it is precisely this kind of temporal limitation which is fundamentally characteristic of play: it can suspend the time and meaning of the world out of which it springs, but it is not its purpose to change that world in any but this temporary sense. The Dionysian play, whether in its original form or its artistic form, remains fundamentally play; insofar as this is the case, it can meet the challenge posed by the primordial contradiction of existence only in a temporary way.

Apolzinian Play

If Dionysian play gives itself over to intoxication and selfoblivion, there remains another way of dealing with the abys which the primordial pain leaves gaping in front of man. This is to create another world, a safer, more clearly defined and predictable one. Such a world is necessary if man is to survive. 30 The barbaric form of Dionysian play, because it leads eventually to the destruction of life, must be overcome. A veil of illusion must be drawn across the horrors of existence revealed by the Dionysian experience. For the Greeks, it was a veil composed of the 01ympian world of the gods, the Apollinian sense of beauty, Homeric epic, and 1ater Greek phi1osophy itself. But even more fundamental than these is the preartistic manifestation of the Apollinian: the dream.

$30_{\mathrm{GT}}, 3$; III/1, p. $32=\mathrm{BT}, 3$, p. 42. "Um 1eben zu können, mussten die Griechen diese Götter, aus tiefster Nöthigung, schaffen. - . So rechtfertigen die Götter das Menschenleben, indem sie es selbst leben..." 
The dream, and the entire Apollinian world, spring forth from the need for illusion, which itself is felt to be rooted in the very nature of primordial reality for Nietzsche.

For the more clearly I perceive in nature those omnipotent art impulses, and in them an ardent longing for illusion, the more I feel myself impelled to the metaphysical assumption that the truly existent primal unity, eternally suffering and contradictory, also needs the rapturous vision, the pleasurable i1lusion. for its continuous redemption. 31

In this sense. the creation of illusion, the plaving with the real in images, which characterizes the Adollinian consciousness, is felt to be rooted in the ground of being itself. ${ }^{32}$ All existence cries for redemption through illusion. The dream, a natural manifestation of this urge in human existence, is but an aspect of the larger process of existence seeking to redeem itse1f.

In dreams a certain sense of form and measure comes to the

$31_{\mathrm{GT}}, 4$; III/1, p. $34=$ BT, 4, pp. 44-45. "Je mehr ich näm1 ich in der Natur jene allgewaltigen Kunsttriebe und in ihnen eine inbrünstige Sehnsucht zum Schein, zum Erlöstwerden durch den Schein gewahr werde, um so mehr fühle ich mich zu der metaphysischen Annahme gedrängt, dass das Wahrhaft-Seiende und Ur-Eine, als das ewig Leidende und Widerspruchsvolle, zugleich die entzückende Vision, den lustvollen Schein, zu seiner steten Erlösung braucht . . ."

32 While Nietzsche mentions here that this is a feeling, it should be noted that the entirety of The Birth of Tragedy is characterized by a certain absence of argumentation in regard to its basic position. Eugen Fink is fundamentally correct when he maintains the following:

Wie eine einzige, großartig in sich geschlossene Vision tritt uns Nietzsches Kunst-Metaphvsik gleich zu Beginn des Buches entgegen. in den Grundzügen fertig: es gibt hier keinen Versuch, den Weg zu zeigen, wie er zu seinen Thesen kam; nirgends wird überhaupt reflektiert über Recht oder Unrecht der tragenden ontologischen Konzeption.

Nietzsches Philosophie(Stuttgart: Kohlhammer Verlag, 1960), p. 24. 
fore. In them, "we delight in the immediate understanding of figures; all forms speak to us; there is nothing unimportant or superfluous"33 Indeed, the dream is not a mirror image of the primordial contradiction, but a transfiguration of that contradiction. This is the essence of the Apollinian play with the real on the level of nature: the transformative redemption of the primordial contradiction of existence through the creation of illusion in dreams.

This transformation is, however, never quite complete, for there is always the lingering realization that it is a transformation, that something else lurks behind it--in short, that it is an illusion. Thus, "even when this dream reality is most intense, we still have, glimmering through it, the sensation that it is mere appearance. While it belongs to the very essence of the primordial contradiction to create these illusions, the illusions themselves have only that reality proper to appearance. They are the attempt of existence to redeem itself in the transformative play of images.

If the Apollinian as a natural force manifesting itself in dreams is the game which individual men play with the real by the creation of an alternate world of appearance, Apollinian art is

${ }^{33} \mathrm{GT}, 1$; III/1, p. 34 . "Wir geniessen im unmittelbaren Verständnisse der Gestalt, alle Formen sprechen zu uns, es giebt nichts Gleich́gültiges und Unnöthiges."

${ }^{34} \mathrm{GT}, 1$; III/1, p. $22=$ BT, 1, p. 34. "Bei dem höchsten Leben dieser Traumirklichkeit haben wir doch noch die durchschimmernde Empfindung ihres Scheins . . ." 
playing with these dreams: the creating of illusion becoming conscious of itself. With this, certain rules make their appearance: harmony, measure, balance and stability beomce most important. These arise out of the need to resolve the contradictoriness of primordial existence and thereby to redeem it, to justify it. This is not done by actually changing the ground of being, but rather by giving it its "complement and consummation."35 Insofar as being comes to mean stability. insofar as it is taken as the opposite of becoming, this world of appearance finally is taken to be the world of being, while the primordial oneness and its contradictions become the world of becoming, of continual change.

The play of the Apollinian artist is not an arbitrary activity, but rather the extension of nature's own drive toward the creation of illusion.

If, for the moment, we do not consider the question of our own 'reality,' if we conceive of our empirical existence, and that of the world in general, as a continually manifested representation of the primal unity, we shall then have to look upon the dream as an appearance of an appearance, hence as a still higher appeasement of the primordial desire for mere appearance. And that is why the innermost heart of nature feels that ineffable joy in the naive artist and the naive work of art, which is likewise only 'mere appearance of mere appearance,'36

$$
\begin{aligned}
& { }^{35} \mathrm{GT}, 3 ; \operatorname{III} / 1, \text { p. } 32=\mathrm{BT}, 3, \mathrm{p} .42 . \\
& { }^{36} \mathrm{GT}, 4 ; \operatorname{III} / 1, \text { p. } 35=\mathrm{BT}, 4, \mathrm{p} .45 \text {. "Sehen wir a1so einma1 }
\end{aligned}
$$
von unsrer eignen 'Realität' für einen Augenblick ab, fassen wir unser empirisches Dasein, wie das der Welt iberhaupt, als eine in jedem Moment erzeugte Vorstellung des Ur-Einen, so muss uns jetzt der Traum als der Schein des Scheins, somit als eine noch höhere Befriedigung der Urbegierde nach dem Schein hin gelten. Aus diesem selben Grunde hat der innerste Kern der Natur jene unbeschreibliche Lust an dem naiven Künstler und dem naiven Kunstwerke, das gleichfalls nur 
In this sense Apollinian art represents the consummation of the drive of existence to redeem itself.

Just as the primitive Dionysian consciousness and Dionysian art have their limitations, so do the natural Apollinian experience and Apollinian art. Dreaming, as playing with reality by transforming it into images, again does not fundamentally change primordial reality or its contradictoriness and pain. It can create an illusion, but it remains just that: an izlusion. This is doubly true for Apollinian art, which is the appearance of an appearance. It is still the case, however, that Apollinian consciousness and Apollinian art are not as temporally limited as their Dionysian counterparts. The Apollinian, in fact, appears to pervade much of what one would call "everyday reality." Its emphasis on harmony. measure and proportion contributes to its more permanent character. There is, however, a more severe limitation upon the Apo1linian: the constant threat stemming from the Dionysian. This, perhaps more than any other factor, prevents the Apollinian illusion from ultimately being taken as all of reality. In a similar manner, the Apollinian stands as a constant threat to the Dionvsian, for the Apollinian appears to be rooted in a fundamental longing of existence to redeem itself through illusion.

'Schein des Scheins' ist." 
The Contrast Between the Dionusian and the Abollinian

Both the Anollinian and the Dionysian are types of play rooted in the nature of primordial existence. in its contradictory character. While they exist in a hostile relationship toward each other, it is clear that they need one another. ${ }^{37}$ Nevertheless, they differ radically in a number of respects, the elucidation of which points to the ambivalent role of the concept of play in Nietzsche's thinking about the Greeks.

Whereas Apollinian art leads to a strengthening of the principle of individuation, 38 the Dionysian intoxication brings about a reconciliation of man with his fellow man and with nature itself, thereby bringing about the negation of the principle of individuation. ${ }^{39}$ In the first case, existence is a game needing its completion in illusion in an alternate world. In order to fulfill this need, the Apollinian artist must in effect live in two worlds: the

37 The basic interdependence of the Dionysian and the Apo1linian is described quite well by Eugen Fink as follows: . . . sie [the Apollinian and the Dionysian] können nicht ohne einander sein; ihr Streit, ihre Zwietracht ist auch eine gewisse Eintracht, sie sind als die Kämpfenden verbunden; die apollinische Kunstwelt der Griechen, die Entscheidung für das Maß und seine Fügung, beruht auf dem immer lebendigen, nur unterdrückten Grunde titanischer Maßlosigkeit; das Dionysische ist der Untergrund, auf dem die lichte Welt aufruht. . . Nietzsches Philosophie, pp. 24-25.

${ }^{39} \mathrm{GT}, 4 ; \mathrm{III} / 1$, p. $35=\mathrm{BT}, 4$, p. 45. "Apollo aber tritt uns wiederum als die Vergöttlichung des principii individuationis entgegen, in dem allein das ewig erreichte Ziel des Ur-Einen, seine Erlösung durch den Schein, sich vollzieht..."

$$
{ }^{40} 0_{\mathrm{GT}}, 1 ; \mathrm{III} / 1, \mathrm{p} .25=\mathrm{BT}, 1, \text { p. } 37 ; \mathrm{GT}, 2 \text {; III } / 1, \text { p. } 28=
$$
BT, 2, p. 40 . 
one of appearances which he creates and, insofar as he creates this world and thus stands outside of it as creator, another, darker world, closer to the primordial pain of existence. The Apollinian artist alienated himself from this latter world through his creation of illusion. and it is this alienation which allows for the appearance of the individua1--indeed, necessitates it. In order to complete existence. he must seperate himself from it. The Dionysian seeks to overcome such alienation, to become one with nature and other men, but it is for precisely this reason that the Dionysian poses a threat to culture; such a reconciliation would destroy its very foundation. A completely unalienated individual becomes a contradiction in terms; he would be so completely one with existence that he would cease to be an individual.

A parallel tension arises between the respective media of expression for the Apollinian and the Dionysian artists. The plastic arts, the image, offer the possibility of clear definition, strong lines, balance, while music allows one to forget the self, to merge with the flow of sensation. So, too, the Apollinian play tends to be more static than the Dionysian one: a world in which each thing has its place (indeed, one in which there are things) and remains constant, whereas a world of music can never come to rest. This tension between rest and motion is complemented by one between space and time: the Apollinian world expresses itself primarily in spatial terms, while the Dionysian one is basically temporal in character. Thus, through the mediation of the artist, existence plays 
two distinctly different types of games with itself. The one is a game of the individual, measure, the image, being as rest in space; the other is a game of unity, the shattering of all divisions, musical, the flux of becoming in time. In this sense, existence is at its very heart contradictory, going in two mutually exclusive directions simultaneously, playing one direction off against the other, incapable of achieving any final resolution, at least insofar as such a resolution would imply a true transcending and unification of these fundamentally contradictory powers of primordial existence. The Tragic

If a final reconciliation of the Apollinian and the Dionysian is impossible, if they are doomed to struggle against each other endlessly, they remain, as shown above, in need of each other. It is here that the final meaning of play emerges in Nietzsche's analysis of the Greeks: the tragic is the unending interplay of these two different types of games which existence plays with itself. Each of these worlds is justified on its own terms, but each is incompatible with the other. Tragedy arises because they can never truly exist only on their own terms, but are continually doomed to transgress into each other's world because of their mutual interdependence.

When these two worlds come together in one individual, one encounters one of the purest manifestations of the tragic.

The misfortune in the nature of things... the contradiction at the heart of the world reveals itself to him [the Aryan] as a clash of different worlds, e.g., of a divine and a human one, 
in which each, taken as an individual, has right on its side, but nevertheless has to suffer for its individuation, being merely a single one beside another. In the heroic effort of the individual to attain universality, in the attempt to transcend the curse of individuation and to become the one worldbeing, he suffers in his own person the primordial contradiction that is concealed in things, which means that he commits sacrilege and suffers. 40

The most basic form of this collision of two worlds is the coming together of the Apollinian and the Dionysian. The accompanying ug1iness and disharmony can only be justified as an aesthetic phenomenon, as "part of an artistic game that the will in the eternal amplitude of its pleasure plays with itself." 41

Insofar as the Dionysian and the Apollinian constitute the two fundamental directions of existence, the two types of games which the primordial one plays with itself, then the Apollinian and the Dionysian are also the two basic aspects of human existence. 42

$40_{\mathrm{GT}}, 9 ;$ III/1, pp. $65-66=\mathrm{BT}, 9$, p. 71. "Das Unheil im Wesen der Dinge... . der Widerspruch im Herzen der Welt of fenbart sich ihm als ein Durcheinander verschiedener Welten, z.B. einer göttlichen und einer menschlichen, von denen jede als Individuum im Recht ist, aber als einzelne neben einer andern für ihre Individuation zu leiden hat. Bei dem heroischen Drange des Einzelnen ins Allgemeine, bei dem Versuche über den Bann der Individuation hinauszuschreiten und das eine Weltwesen selbst sein zu wollen, erleidet er an sich den in den Dingen verborgenen Urwiderspruch d.h. er frevelt und leidet."

$$
41_{\mathrm{GT}}, 24 ; \mathrm{III} / 1, \text { p. } 148=\mathrm{BT}, 24, \text { p. } 141 \text {. ". . . ein künst- }
$$
lerisches Spiel ... , welches der Wille, in der ewigen Fülle seiner Lust, mit sich selbst spie1t."

${ }^{42}$ In The Birth of Tragedy, Nietzsche's argument begins with the Apollinian and Dionysian as human artistic drives, moves from them to the dream and intoxication as fundamental powers of being, and then interprets these original artistic drives in terms of these metaphysical principles. Cf. Eugen Fink, Nietzsches Philosophie, p. 25 on the structure of the argument here. 
The tragic individual is the place where they come together with full force, where they attempt to become reconciled with each other rather than simply try to conquer each other. The relationship between the two is one of struggle until it is transformed as an aesthetic phenomenon, at which point it becomes artistic play. On the Adequacy of Play

Two main themes govern the line of investigation here. The first of these is primarily expository and interpretative, showing the category of play is in fact fundamental to Nietzsche's thinking during this period. The second is critical and involves questioning the adequacy of the category of play in this context. In regard to the first theme, it has been shown, not only that the category of play occupies a central place in Nietzsche's thinking during this period, but also that the category of play is common to the three fundamental categories in terms of which Nietzsche analyzes existence: the Apollinian, the Dionysian and the tragic. As such, it provides the unifying category in terms of which his overall view of existence can be understood.

Some progress has already been made in regard to the second line of investigation. It has been shown that both Dionysian play and Apollinian play have certain inadequacies, that they never stand alone. It was further shown that these inadequacies existed against a background of a primordial contradiction in existence. The nature of this contradiction is such that no form of play can adequately reconcile the contradictoriness of existence. It can only suspend 
or conceal one side of the contradiction temporarily; but that hidden side continues to exist. Tragedy does not achieve this reconciliation because it fails to eliminate the contradiction; it does, however, raise that contradiction to the level of an aesthetic phenomenon, a game which the will plays with itself.

What would constitute an adequate category of play, given the presence of this primordial contradiction. If a criterion of adequacy is the ability to overcome and eliminate this contradiction, then clearly the category of play remains inadequate. In fact, any category would be a priori inadequate, since it is impossible to change such a fundamental reality.

It is important to note, however, that this primordial contradiction is itself an assumption on Nietzsche's part, taken for granted throughout his writings here but never justified. Once this assumption is made, life is condemned to futility, incapable of finally eliminating the contradiction of existence. It is absurd to think of changing the world, of improving the human condition in any way, because in the end all such changes and improvements dwindle into insignificance when seen within the framework of this primordial contradiction. Some notion of play is practically the only alternative available, given the framework Nietzsche has as sumed.

There is another aspect to this framework which is neglected in The Birth of Tragedy. In the forward to an unwritten book on the Greek state, Nietzsche discusses the notions of dignity of man 
and the dignity of work. These remarks offer a valuable insight into the background of Nietzsche's idea of the Apollinian and the Dionysian and into the conditions under which the emergence of the two forces is possible. Nietzsche argues that in order for work to be considered dignified, existence itself must have some claim to dignity. The Greeks are clearly to be praised because they had no need for such conceptual hallucinations such as the dignity of existence. They recognized the true nature of things.

Work is a dishonor because existence has no value in itself; but if even this existence sparkles in the seductive jewels of artistic illusion and now really appears to have a value in itself the proposition that work is a dishonor is still valid

Even artistic creation falls under the category of work for the Greeks, and the presence of the artistic drive is but evidence that the artist is subjected to the necessity of work.

In this situation man develops a feeling of shame when he realizes that he is only the tool of forces much greater than himself, that he is the pawn of necessity. These feelings of shame, dishonor, and necessity belong to the experience of work and slavery, and an examination of them reveals the truth of culture itself.

In order to provide a broad, deep and rich foundation for the development of art, the overwhelming majority must be put

43"Fünf Vorreden. Der griechische Staat," III/2, p. 259. "Die Arbeit ist eine Schmach, weil das Dasein keinen Werth an sich hat: wenn aber eben dieses Dasein im verführenden Schmuck künstlerischer Illusionen erglänzt und jetzt wirklich einen Werth an sich zu haben scheint, so gilt auch dann noch jener Satz daß die Arbeit eine Schmach sei..." 
slavishly in the service of a minority, going above the measure of their individual neediness. At their expense, through their surplus work, that privileged class shall be removed from the struggle for existence in order to create a new world of needs and satisfy them. 44

This makes it clear for Nietzsche that, "slavery belongs to the essence of culture: a truth which clearly leaves no doubt about the absolute value of existence."45 It is nature which is at work in all this, "forging the monstrous tool of the state," seeking "through society to come to its redemption in appearance, in the mirror of genius." 46

In the passages in his notebooks which immediately precede this preface, Nietzsche makes it clear that the purpose of culture is to allow for the appearance of genius--Apollinian, Dionysian, and tragic. ${ }^{47}$ This casts a different light on the previous analysis.

44 Ibid., p. 261. "Damit es einen breiten tiefen und ergiebigen Erdboden für eine Kunstentwicklung gebe, muß die ungeheure Mehrzahl im Dienste einer Minderzah1, uber das Maaß ihrer individuellen Bedürftigkeit hinaus, der Lebensnoth sklavisch unterworfen sein. Auf ihre Unkosten, durch ihre Mehrarbeit soll jene bevorzugte Klasse dem Existenzkampfe entrückt werden, um nun eine neue We1t des Bedürfnisses zu erzeugen und zu befriedigen."

45Ibid., p. 261. "Demgemäß müssen wir uns dazu verstehen, als grausam klingende Wahrheit hinzustellen, daß zum Wesen einer KuItur das SkLaventhum gehöre: eine Wahrheit freilich, die über den absoluten Werth des Daseins keinen Zweifel übrig läßt."

46 Ibid., pp. 264-65. "Hier sehen wir wiederum, mit welcher mitleidlosen Starrheit die Natur, um zur Gesellschaft zu kommen, sich das grausame Werkzeug des Staates schmiedet . . . durch die Gese11schaft zu ihrer Erlösung im Scheine, im Spiegel des Genius, zu kommen"'

${ }^{47}$ Posthumously published notebooks in Die Geburt der Tragödie. Der griechische Staat, p. 205. 
Whereas in The Birth of Tragedy the background of play was a metaphysical one, the primordial contradiction and pain of existence, this is now made more concrete. The societal correlate of this original contradiction is revealed in the dichotomy between slavery and the play of genius. Play can take place only within the context of slavery for Nietzsche. Such slavery is, however, justified--or, more precisely, not in need of justification--because existence in itself has no value anyway.

It is here that I think one encounters one of the true dangers of a philosophy of play. As Nietzsche develops the problem in his early writings, it is clear that there is an absolute division between work and play. As a consequence of this, certain restrictions are established on both work and play such that both are incapable of providing true satisfaction for man. It is clear from this description that work has no dignity for Nietzsche, that it is equivalent to slavery, characterized by feelings of shame, dishonor and domination by necessity. True human creativity finds its expression in the three forms of play developed here. But this expression is foreordained to an ultimate lack of meaning; while it can cover up the pain of primordial existence for a time, it cannot ultimately change anything. It can only create illusions which momentarily suspend that pain and contradiction. Any action in the world is denied to it in advance because it involves the creation of an alternate world. There is no structure of mediation which can adequately bring these two worlds together. As a result of this, one realm of 
activity deals with the averyday world and changes it, but it is unable to escape the burden of need, the domination of necessity. The other realm of activity is indeed free from such need, although this freedom is paid for by the slavery of the majority, but it cannot really change anything with the freedom that it receives. Nietzsche would, I think, argue at this point as follows. First, my criticisms reflect the way I would like things to be, but -Nietzsche would argue--he is showing us the way things are, the horrible truth of existence, without making a value judgment about it. Second, no alternative is possible except the one present by him, because the primordial pain and contradiction of existence cannot be changed by human activity. Third, such phrases as "cannot rea1ly change anything" indicate a very specific notion of reality, one in which "really" refers to the world of everyday activity. Such a narrow definition of reality would be unacceptable to Nietzsche. The difficulties with these Nietzschean criticisms lead to the most fundamental questions about the nature of reality itself. Not only is it impossible to settle such questions here in a definitive manner, it is also unnecessary at this point if one considers the problem only in relation to Nietzsche. His position, as has been pointed out above, is based on an assumption about the nature of nrimordial existence as pain and contradiction. Throughout his writings during this period, this position is assumed, not proved. He certainly never proves that things could not be otherwise, that it is impossible to alter the basic character of existence, even 
presuming that his description of it is adequate. The assumption of an irreconciliable contradiction at the heart of existence, expressed in the contradiction between the Apollinian and the Dionysian, is the basis for denying any value to existence in itself and for developing a notion of play as a temporary suspension of one side of that contradiction. It also provides the foundation for a devaluation of work, a denial of the dignity of work, and a justification of the slavery of the majority in the service of the play of genius. This seems to be rather a lot to base simply on an assumption. Conclusion

This brief consideration of the role of the category of play in Nietzsche's analysis of Greek tragedy and culture provides the starting point for a systematic approach to the meaning of play in Nietzsche's philosophy by delineating the various meanings of the category itself. Play can be considered either as a category descriptive of primordial existence itself or as referring to artistic activity where the mediation of the human artist is a necessary component of the process. Alternately, it can be considered as a way of becoming one with the flux of existence in intoxication with an accompanying shattering of the principle of individuation, or it can refer to the creating of illusions in order to mask both the Dionysian threat to the individual and the primordial pain arising out of the contradiction of existence. In the latter case, it involves the creation of a world of order and stability, in sharp contrast to the Dionysian experience of flux and unity. "These divisions cut 
across one another, yielding the four-fold division of play which Nietzsche outlined in "The Dionysian Worldview." The interaction of these two basic forces in existence, the Dionysian and the Apollinian, gives rise to the final meaning of play: the tragic play of existence itself, an overarching category which includes the previous senses of play. The category of play is the fundamental one in terms of which both existence in general and the specific forms of existence are understood in Nietzsche's writings during the period of The Birth of Tragedy.

The category of play, however, proves itself to have certain inadequacies, two of which have been discussed above. First, the category of play is predicated against a background of the primordial pain and contradiction of existence, but this background proves itself to be only an assumption. Thus the specific character of Nietzsche's category of play is determined by a mere assumption. Second, when seen on the level of society, Nietzsche's category of play is situated within the context of, and dependent upon, slavery. The result is that play is condemned to being ineffectual in the world, while work is completely under the domination of necessity, shame and dishonor. The categories of work and play are unmediated and, indeed, mediation is impossible at this stage. 
CHAPTER III

PLAY AS THE HIGHEST FORM

OF HUMAN ACTIVITY

\section{Introduction}

The category of play, central to Nietzsche's early writings about Greek tragedy and culture, reappears in his later writings in the form of an ideal. Although the status of ideals is itself a problematic point in Nietzsche's philosophy which will have to be discussed below, it remains true that play represents for Nietzsche the highest form of human activity. This is exceptionally clear in the passage in Thus Spoke Zarathustra on "The Three Metamorphoses," and it is also to be found in Nietzsche's treatment of the free spirit and in his doctrine of the order of rank. In each instance, it is in play that human activity reaches its highest expression.

In this chapter I shall approach a demonstration of the thesis that play is the highest form of human activity for Nietzsche in two ways. First, it will be shown to be true in a positive sense by examining the three ideals for human existence mentioned above: the image of the child in "The Three Metamorphoses," the free spirit, and those who are highest in the order of rank. It will be shown in each case that the kind of activity proper to each is playing. Second, it will also be shown in a negative sense that play must be the highest form of human activity. This will be established by 
showing that play is the only form of human activity which allows for the justification of existence in the face of the experience of nihilism. In the post-nihilistic world, play emerges as the form of human activity which permits both a full recognition of the cha1lenge of nihilism and at the same time a complete affirmation of human existence in itself.

By considering only these specific concepts in this chapter, I do not want to give the impression that I think these are the only models of human existence which Nietzsche considers to be significant. This is obviously not the case. Two central notions are conspicuous by their absence here: the doctrines of the overman and of the will to power. Each of these will be considered in the following chapters. Chapter Four will extend the interpretation developed here to the notion of the will to power and morality, while Chapter Five will consider the doctrine of the overman in relation to Nietzsche's idea of the self and the play of affects.

As in the previous chapter, there is a second major theme which runs throughout this chapter. In addition to establishing the centrality of the category of play to Nietzsche's view of human activity, I have endeavored to critically examine the adequacy of this category both within Nietzsche's philosophy and, to a lesser extent, in itself. In this regard, I have pointed to certain tensions which develop in a philosophy of human activity as play such as Nietzsche's and have shown the degree to which these can be overcome within a Nietzschean framework. 
A. The Ideal of Creative Play

The Three Metamorphoses

In the first of Zarathustra's speeches in Part One of Thus Spoke Zarathustra, Zarathustra presents a paradigm for the development and liberation of the spirit in three stages, symbolized by the camel, the lion, and the child. ${ }^{1}$ In this section dealing with "The Three Metamorphoses," I shall show that in this model for understanding human existence play is clearly the highest form of human activity. In addition to this, it will be shown that this stage of creative play cannot be achieved without prior preparation. The stages of development represented by the camel and the lion must be lived through first in order that play in its fullest form can be possible. The experiences of the lion and the camel are prior conditions of the possibility of the emergence of creative play on the part of the child and give us important insights into the nature and foundation of that play. Finally, the adequacy of this category of creative play will be discussed; special attention will be paid to the question of the relationship between the player and his fellow players and those who stand outside of that play--in other words, to the social dimension of the category of play as developed in "The Three Metamorphoses."

l"Von den drei Verwandlungen," Also Sprach Zarathustra, in Nietzsche Werke, Kritische Gesamtausgabe, Sechste Abteilung, Erster Band (Berlin: Walter de Gruyter, 1968), pp. 25-27 = "On the Three Metamorphoses," Thus Spoke Zarathustra, translated by Walter Kaufmann (New York: Viking, 1966), pp. 25-27. Hereafter abbreviated as " $\mathrm{Z}$," followed by chapter or speech title, volume and page numbers. 
Before turning to the text itself, two prefatory comments are in order. First, although the passage under consideration does not present adequate evidence for concluding that ther can be only three stages in this process of liberation, it is clear that these stages represent a complete process, in particular in relation to its endpoint. However, if the three metamorphoses culminate with the child as the highest stage in the development of the spirit, there is still room for other stages before this entire process begins, stages in which the spirit has not yet developed the awareness found in the stage of the came1.

Second, attention should be called to the subject of this process of transformation: spirit. Although Nietzsche does not define precisely what he means by spirit, the speech in Book Two of Thus Spoke Zarathustra "On the Famous Wise Men". gives an indication of the sense in which the term is employed. Spirit is, "the life that itself cuts into life: with its agony it increases its own knowledge," 2 and its happiness is, "to be anointed and through tears to be consecrated as a sacrificial animal." 3 spirit is thus that form of life which allows itself to be sacrificed in order to lead to something beyond itself. In this sense, spirit is a self-transcending

2 , II, "Von den berïhmten Weisen;" VI/1, p. $130=\mathrm{Z}$, II, "On the Famous Wise Men," p. 104. "Geist ist das Leben, das selber in's Leben schneidet: an der eignen Qual mehrt es sich das eigne Wissen -. ."

${ }^{3}$ Ibid. "Und des Geistes Gluick ist diess: gesalbt zu sein und durch Thränen geweiht zum Opferthier . . ." 
form of life. The three metamorphoses are distinct stages of life cutting into life, in particular into the illusions which had previously been necessary if life was to continue. The spirit's happiness, however, can be something more than that of the sacrificial animal, as well be shown below in the discussion of the child. Suffice it to say here that spirit is that form of life which cuts into itself, goes beyond itself in the ways which will be discussed in "The Three Metamorphoses."

The Camel. The starting point of this process of transformation is "the spirit who would bear much."4 He asks for that which is most difficult, for this is what his strength demands. It is by demanding the most difficult that life cuts into itself in this first stage, goes beyond itself. The most difficult is defined in this passage through a series of questions, which are implicitly given an affirmative answer. It consists of:

-. humbling oneself to wound one's haughtiness . . . letting one's folly shine to mock one's wisdom . . parting from our cause when it triymphs. . climbing high mountains to tempt the tempter...

What the spirit's strength demands would appear to be the negation of

${ }^{4} \mathrm{Z}$, "Von den drei Verwandlungen;" VI/1, p. $25=\mathrm{Z}$, "On the Three Metamorphoses," p.'25. "Vieles Schwere giebt es dem Geiste, dem starken, tragsamen Geiste..."

${ }^{5}$ Ibid., p. $25=$ Ibid., p. 26. ". . . sich erniedrigen, um seinem Hochmuth wehe zu thun . . Seine Thorheit leuchten lassen, um seiner Weisheit zu spotten . . von unserer Sache scheiden, wenn sie ihren Sieg feiert.. . Auf hohe Berge steigen, um den Versucher zu versuchen . . ." Four other examples are mentioned in the text. 
its strength, but it would be more precise to say that it demands the full affirmation of the opposite of one's strength as well as of the strength itself. The point Nietzsche is making here is that a strength which does not include the recognition and affirmation of its own opposite weakness is itself only a limited strength precisely because it does not recognize its own limits as strength. Our wisdom, for example, must recognize and affirm the presence of our folly in order for us to fully know our limits, the true extent of its own strength. Not to do so is to fall prey to our own weakness. In order to overcome this weakness, to do what one's strength demands, one must thus affirm one's weakness along with one's strength, transcending it as a weakness by knowing and willing it.

Implied in the description of the transformation of the spirit from a camel to a lion is that the "Iord and god" of the camel is the "thou shalt," which represents "values, thousands of years old.. . all created value." The totality of these values has al ready been created, leaving no room for the "I will." Does this mean that the "thou shalt" is the fundamental character of the camel's existence? It is fundamental only in a very specific sense. The "thou shalt" is one of the strengths--perhaps the greatest one-of the spirit's existence at this stage. The camel's task as spirit is to assume not only this strength but also its opposite. The necessity of assuming the opposite of the strength as well as the strength itself introduces the principle of transformation at the heart of the camel's strength, presuming that the opposite of the 
"thou shalt" is the affirmation of the individual's will. The assumption of the greatest strength and its negation leads the camel to the negation of this whole mode of existence and pushes him toward the second stage, that of the "I will." Thus the principle of transformation is to be found in the camel as spirit.

In a fragment from his notebooks entitled, "The Way to Wisdom: Pointers on the Overcoming of Morality," Nietzsche develops a three stage process that roughly parallels the three metamorphoses found in Thus Spoke Zarathustra. It sheds some light on the concrete meaning of the camel.

The first path. Worshipping (and obeying and learning) better than anyone else. Assimilating all things that are venerable and letting them struggle with one another. Bearing every burden. Asceticism of spirit--bravery. A time of fellowship.

[The overcoming of evil, petty inclinations. The encompassing heart; one conquers only with love. Fatherland, race, everything belongs here. (Richard Wagner prostrated himself before a deep, loving heart; Schopenhauer also. This belongs to the first stage). $]^{6}$

In this description of the first stage, there is a stronger emphasis on the implied "thou shalt"; instead of assimilating all things

${ }^{6}$ Friedrich Nietzsche, Die Unschuld des Werdens. Der Nachlass, selected and ordered by Alfred Baeumler (Stuttgart: Kröner Verlag, 1956), Volume I, p. 249, \$662. "Der erste Gang. Besser verehren (und gehorchen und Zemen) als irgendeiner. Alles Verehrenswerte in sich sammeln und miteinander kämpfen lassen. Alles Schwere tragen. Asketismus des Geistes--Tapferkeit. Zeit der Gemeinschaft.

"[Die Überwindung der bösen, kleinlichen Neigungen. Das umfängliche Herz: man erobert nur mit Liebe. Vaterland, Rasse, alles gehört hierher. (Richard Wagner warf sich vor einem tiefen, liebvollen Herzen nieder; ebenso Schopenhauer. Dies gehört zur ersten Stufe.)]" (Brackets in original.) 
without qualification, one assimilates all things "that are venerable." In a sense, one becomes transparent; one mirrors the struggle of those forces one assimilates, becomes their background.

The descriptions of the camel and this first path present a basic way of being in the world which has the following characteristics: extending one's world to encompass as much as possible, especially the difficult, thereby extending one's self; an affirmation of one's existence by binding oneself not only to one's strengths but also to one's weaknesses; the discovery of the implicit act of will which underlies this affirmation and leads finally to the negation of the most important part of that which was affirmed: the "thou shalt." This conflict with the "thou shalt" is implicit in each of the other acts of reverence insofar as they demand the affirmation of opposites. The "I wil1" is already hidden in the camel's choice to test his own strength, and the more he affirms opposites, the greater the tension between the "thou shalt" and the "I will."

The Lion. One of the reasons for the emergence of the lion has just been discussed: the "I will" is implicit in the camel's choice to take on the heaviest burdens. Nietzsche puts the question of the necessity of this transformation in Zarathustra's words :

My brothers, why is there a need in the spirit for the lion? Why is not the beast of burden, which renounces and is reverent, enough?

To create new values--that even the 1 ion cannot do; but the creation of freedom for oneself for new creation--that is within the power of the lion. The creation of freedom for 
oneself and a sacred "No" even to duty--for that, my brothers, the lion is needed. 7

The emergence of the lion from the camel is necessary as a condition of the possibility of creating new values, of the creative play of the child in the next stage. But why is the creation of new values necessary? At this juncture two lines of argumentation are possible. On the one hand, one can argue the necessity of this transformation on the basis of the internal contradictions in the stage of the camel. In addition to the arguments presented above in this connection, one could argue that one of the values which one affirms at the stage of the camel would be that of freedom, which in the end challenges the "thou shalt." This line of argument parallels the interpretation of European nihilism found at the beginning of The Wilz to Power: beginniing with an affirmation of Christian moral values (which include truthfulness), one is led in this quest for truth to the denial of those original values one affirmed as their falsity is uncovered, destroying the entire worldview upon which even one's concept of truthfulness (and its value) rested. So too, the camel's affirmation of traditional values (including freedom)

$7 Z$, I, "Von den drei Verwandlungen;" VI/1, p. $26=2$, I, "On the Three Metamorphoses," p. 27. "Meine Brüder, wozu bedarf es des Löwen im Geiste? Was genügt nicht das lastbare Thier, das entsagt und ehrfürchtig ist?

"Neue Werthe schaffen--das vermag auch der Löwe nicht: aber Freiheit sich schaffen zu neuem Schaffen--das vermag die Macht des Löwen.

"Freiheit sich schaffen und ein heiliges Nein auch vor der Pflicht: dazu, meine Brüder, bedarf es des Löwen." 
would lead it to challenge that entire set of values and, in the end, the very value of values--to question whether it is of value to life to live under the domination of the "thou shalt."

A second possible line of argumentation would deny any real necessity to the appearance of the lion except a conditional one: if freedom is to appear, then the lion is necessary, but the appearance of freedom is not necessary in itself because it involves a free act. On the basis of the text of "The Three Metamorphoses," the second interpretation is to be preferred; but the first, even if it does go beyond the text, seems to be a valid interpretation if one qualification is added. This process is not necessary in itself; that is, a given spirit may never be able to go beyond the first stage. If, however, he does, the first argument helps us to understand some of the forces at work which made this possible.

The lion's being in the world is to be found in freedom, in the negation of the "thou shalt," in a sacred "no" to everything one had previously affirmed. Truthfulness sets him off from other men. 8 The same phenomenon is described in "The Way to Wisdom" as follows.

The second path. To break the worshipping heart when one is most strongly committed. The free spirit. Independence. Time of the desert. Critique of everything that has been venerated

${ }^{8}$ The element of truthfulness is emphasized in $Z$, II, "Von den berühmten Weisen;" VI/1, pp. $128 \mathrm{ff}=\mathrm{Z}$, II, "On the Famous Wise Men," pp. $102 \mathrm{ff}$. If truthfulness is the principle governing the existence of the lion, the lion stage may be considered as the logical consequence of the camel's affirmation of the value of truthfulness, which leads eventually to his calling into question all other values. 
(idealization of all that is not venerated), attempt at reversing evaluations.

[The overcoming also of good inclincations. (Unnoticed such natures as Dühring and Wagner and Schopenhauer have not even once set foot on this level!) ] 9

The more deeply the spirit is committed in the first stage of the camel, the more difficult is this breaking-away; but at the same time, its significance also increases. One gains, in effect, the right to reject all values only when one is first deeply committed to them. Nietzsche is not arguing for an unthinking rejection of the past, for it is precisely that which would constitute a profane "no"; the sacred "no" takes reverence and commitment as its starting-point.

The Child. The final stage of this transformation of the spirit is the emergence of the child, the symbol of human activity as creative play. Asking why the lion must become a child, Zarathustra says:

The child is innocence and forgetting, a new beginning, a game, a self-propelling wheel, a first movement, a sacred "yes." For the game of creation, my brothers, a sacred "yes" is needed: the spirit now wills his own will, and he who had been lost to the world now conquers his own world. 10

${ }^{9} \mathrm{UW}, \mathrm{I}, \$ 662$, p. 250. "Der zweite Gang. Das verehrende Herz zerbrechen, als man am festesten gebunden ist. Der freie Geist. Unabhängigkeit. Zeit der Wüste. Kritik alles Verehrten (Idealisierung des Unverehrten), Versuch umgekehrter Schätzungen.

"[Die Überwindung auch der guten Neigungen. (Unvermerkt solche Naturen wie Dühring und Wagner und Schopenhauer als noch nicht einmal auf dieser Stufe stehend!)]" Brackets in original.

$10_{Z}, I$, "Von den drei Verwandlungen;" VI/I, p. $27=Z, I$, "On the Three Metamorphoses," p. 27. "Unschuld ist das Kind und Vergessen, ein Neubeginn, ein Spiel, ein aus sich rollendes Rad, eine erste Bewegung, ein heiliges Ja-sagen.

"Ja, zum Spiele des Schaffens, meine Brüder, bedarf es eines heiligen Ja-sagens: seinen Willen will nun der Geist, seine Welt 
The innocence of the child arises out of the destruction of the "thou sha1t," an act which puts him beyond good and evil to such an extent that the very distinction is forgotten; in this sense, his appearance marks a new beginning.

What does this child do? He plays creatively. In playing, he creates his own world freely; thus he is a first movement. He lives out, plays out, the game he has begun of his own initiative: a se1f-propelled wheel, returning again and again to its startingpoint to begin another game. The conditions of the possibility of this creative play include not on $1 y$ the appropriation of the world accomplished by the camel and the freedom won by the 1ion, but also the sacred "yes" of the child. The child wills his own will because there is nothing else in itself to will; everything else has become the child's plaything, possessing no value or meaning in itself. The sacred "yes" is then an affirmation, not of any thing in itself in the world, but of the child's own will as the absolute source of meaning and value in the world as his game or play. In this sense, the child not only conquers his own owrld, he creates that world without being bound in any previous one.

The necessity of the transition from the stage of the lion to that of the child appears to be completely conditional: if one is to become creative, then one must go beyond the lion. But, as is

gewinnt sich der Weltverlorene." 
clear in the fragment on "The Way to Wisdom," 11 many are unable to make this transition. The creative play of the child is freely undertaken, hence it is not necessary in itself. Yet one can argue that there is an implicit affirmation of creativity in the 1 ion's negativity which prepares the way for the child's play. In the lion's "no"-saying, he is already taking hold of existence, going beyond it in affirming his right to deny it. When he realizes that this negation arises out of the strength of his own will, he lays the foundation for the child's affirmation of his own will as measure of the world.

While it can be said that playing involves the creation of a world in most cases, the world that is usually created in ordinary play is bounded. Its definition depends upon its juxtaposition to a "real" world. Johan Huizinga, for example, has suggested that, "play is not 'ordinary' or 'real' life. It is rather a stepping out of 'real' life into a temporary sphere of activity with a disposition a11 of its own."12 In this passage on the creative play of the child, the play world becomes the world itself, absolved from any dependence on an ordinary or real world through the liberating transformation of the spirit from a camel through the stage of the lion to that of the child. Here Nietzsche's category of play differs

$$
11 \mathrm{UW}, \mathrm{I}, \S 662, \mathrm{p} .250 .
$$

12Johan Huizinga, Homo Ludens. A Study of the Play Element in Culture, p. 8. 
from many other such theories by attributing to the world of play an autonomy which it does not usually possess. If the commitment of the camel were to encompass all of existence, and if the 1 ion were able to overcome all that to which the camel was committed, then there would be no limits at a11 to the creative play of the child. It is questionable here whether the stage of the child as described in "The Three Metamorphoses" is attainable and, if attained, whether one can remain there for an extended period of time. The questions being raised here parallel those raised about the stability and adequacy of the Dionysian and Apollinian forms of play in the previous chapter. The issue is a crucial one in understanding Nietzsche's category of play and in evaluating its adequacy. The question may be posed this way: is it possible for the creative play of the child to take upon itself an autonomous.existence which is independent of the two preceding stages of the camel and the 1ion? Two possible interpretations present themselves. First, it is possible in the creative play of the child to create a completelv autonomous, self-sufficient world. Second, the creative play of the child is one moment in human activity which in itself comprises all three moments of the camel, the lion and the child.

Nietzsche presents the three metamorphoses as three successive states which, having hapened once to a spirit, do not repeat themselves again under ideal circumstances. To interpret them chronologically as successive stages which clearly be in accord with the text, and such an interpretation would be consistent with Jaspers's 
interpretation of "The Way to Wisdom" as autobiographical.13 Yet this interpretation raises certain problems. Such autonomy is only possible, as has been suggested above, under the conditions that the camel has been able to encompass all of existence and that the 1 ion has been able to negate it and thus free the spirit for his creative play. It is possible to object to the feasibility of such a state on the grounds that such a total encompassing and negating of existence would be practically impossible to achieve. Such an objection would constitute no real objection in Nietzsche's eyes, for he would readily admit that only the very few attain such heights. A second objection carries more weight. In order for such a complete encompassing of, and negating of existence to occur once and for all, it is necessary to assume that existence is static, that the world which it encompassed and then negated does not change. If the world were to change, if something new were to emerge, then that additional "something" would not have been appropriated and negated by the spirit. It would remain outside the spirit's world. However, by means of the camel and the lion, the world itself is transformed into the child's world, from the world to his world. If the play of the child is to be complete, it is necessary either to assume that the world possesses a static character which allows it to be completely

13 For Jaspers's view on this, see Karl Jaspers, Nietzsche. An Introduction to the Understanding of His Philosophical Activity (Tuscon: University of Arizona Press, 1965), pp. $44 \mathrm{ff}$. 
surpassed or else to view the three metamorphoses as three stages which the spirit continually undergoes. Since Nietzsche's world clearly is not a static one, the latter alternative is more clearly in accord with the general framework of Nietzsche's thought.

One can object to this interpretation by raising the following question: why should the creative play of the child not be possible in itself as a continuous creation and destruction of stability, of static worlds? If the creative play of the child is interpreted in this manner, then what I would consider one of the major strong points of Nietzsche's category of play is negated: the connection between the creative play of the child and the everyday world, a connection which is based in the process of transformation which the spirit undergoes in the stages of the camel and the lion, is destroyed. Instead of being the creative transformation of the world through play, the child's play becomes a creatio ex nihito. While such an interpretation is indeed possible, while it can account for the static appearance of the world by treating it as an Apollinian illusion which itself could be the result of creative play, it has two disadvantages in my opinion. First, as already mentioned, it severs any mediating link between the creative play of the child and the world. Second, it appears to me to be an inadequate description of the actual relationship between play and the world if one presumes that the world exists in some sense in itself outside of the child's creative play. In this regard, it has been argued that the three metamorphoses, rather than being stages 
which are temporally successive, are actually interpenetrating metamorphoses. 14

To raise this second objection is to go beyond the questions of what Nietzsche said and of the internal consistency of his statements. It should be clearly indicated as such: it is inquiring into the adequacy of his category of play itself. However, that inquiry reflects back upon the interpretation insofar as one, when confronted with two possible interpretations, tends to choose the one which is more adequate on its own merits. If the creative play of the child is interpreted as a completely autonomous activity which is no longer bound to the world from which it has sprung, then the mediating link between creative play and the world is broken and play loses its connection with the world--presuming the existence of a world in need of mediation. To view the three metamorphoses as continually recurring transformations yields a model which more adequately reflects my own experience. What is significant to me about play is that it is a way of transforming the world; if, on the other hand, it leads merely to creating a private world, then play becomes insignificant. If it is not in some meaningful sense in the world--and the camel and the lion symbolize the ways in which it may be in the world--then it poses its transformative power. It

${ }^{14}$ Ryôgi ôkôchi, "Nietzsches Amor fati," Nietzsche-Studien, edited by Mazino Montinari, Wolfgang Mïller-Lauter and Heinz Wenzel (Berlin: Walter de Gruyter, 1972), Vol. I, p. 89 argues in favor of this view as reflecting the nature of artistic activity in both East and West. 
appears to be mere fooling around (Spielerei), rather than true play (Spiel). It is possible to develop and defend Nietzsche's position without presuming the existence of a world outside of the world of play; but my criticism here is not directed toward the internal consistency of Nietzsche's position, but rather relates simply to a different experience of the relationship of play to the everyday world.

It is not insignificant in this regard that the child's play, as presented in "The Three Metamorphoses," is solitary. He has no fellow players. Whether he is alone at the seashore building sand castles or alone on the top of a mountain, he is nevertheless always alone; his unlimited freedom is purchased at the price of isolation. But isolation is almost too weak a word here: he is not only isolated from other men, he must deny their very existence outside his world of play and the change they bring about in that outside world. One can object to this by asking: can he not, like Prometheus, in his creative play create fellow players, a whole world of things, without having to accept anything given which did not emerge from his creative play? Without his creative play he would be isolated, true, but why should he be isolated in his play from which good neighbors, friends and enemies, etc., emerge? However, the question is, as I see it, how he can create these fellow players if they are not at least present as potential players outside his world of play and if he is not able to draw them into his world in order to actually play together with them and thus constitute them 
as fellow players. He cannot create such players out of nothing although he may be able to radically transform the "something"--the potential players--available to him. The world of play must have a point of insertion into the world out of which it springs, a continuing contact with that world. The symbols of the camel and the lion offer a conceptual framework in terms of which that continuing contact with the world may be understood.

Interpreting the three metamorphoses as continual1y recurring ways of existing is also consistent with the general structure of Thus Spoke Zarathustra itself. In Zarathustra's "Prologue," the beginning of his descent is described as follows:

When Zarathustra was thirty years old he left his home and the lake of $h$ is home and went into the mountains. Here he enjoyed his spirit and his solitude, and for ten years did nof 5 tire of it. But at last a change came over his heart...

At what stage was Zarathustra during his ten years in the mountains? He says, "I am weary of my wisdom. . . I need hands outstretched to receive it."16 The three-stage path considered in conjunction with the three metamorphoses was called "The Way to Wisdom." Did Zarathustra reach wisdom, this third stage? Did he reach the highest

$15 \mathrm{Z}$, "Zarathustra's Vorrede;" VI/1, p. $5=\mathrm{Z}$, "Prologue, p. 9. "A1s Zarathustra dreissig Jahr alt war, verliess er seine Heimat und den See seiner Heimat und gieng in das Gebirge. Hier genoss er seines Geistes und seiner Einsamkeit und wurde dessen zehn Jahre nicht müde. Endlich aber verwandelte sich sein Herz,--"

${ }^{16}$ Ibid., p. $5=$ Ibid, p. 10. "Ich bin meiner Weisheit überdrüssig . . . ich bedarf der Hände, die sich ausstrecken." 
point, the third metamorphosis, and then eventually have to "descend to the depths. . go under"? 17 If Zarathustra fits into the framework of the three metamorphoses at all in this opening passage, it is as the child who enjoys his spirit and solitude for years, but eventual1y wearies of it, needing others to receive it.

But if Zarathustra is the child playing during his sojourn in the mountains, what is he when he goes under? He presents himself as the teacher of the overman and the eternal recurrence, and he refers to the desire to go to his work, his day. 18 Here it depends on whether one interprets play as a completely autonomous activity existing in its own world or as intimately bound up with the other two stages of appropriation and negation which the camel and the lion symbolize. If one follows the second interpretation, then the descent of Zarathustra into the depths is difficult to explain without maintaining that he ceases to play. If, however, one follows the first line of interpretation, one may argue as follows. Play, in order to continue to be meaningful creative activity, must at least periodically descend into the depths, into the world, in order to gather into its own play world new material which it can transform, which it can play with. Zarathustra's world is no longer

${ }^{17}$ Ibid., pp. 5-6 = Ibid., p. 10. ". . . in die Tiefe steigen . . untergehen..."

${ }^{18}$ Z, IV, "Das Zeichen;" VI/1, p. $401=Z$, IV, "The Sign," p. 325. "Zu meinem Werke will ich, zu meinem Tage. . ." 
entirely self-sufficient; he grows weary of it. His activity differs from the child's creative play in "The Three Metamorphoses" in this respect: it seeks others to receive it. There is an implicit recognition here of two shortcomings in the image of the child's play, both of which relate to the social dimension of play. In recognizing that contact with the world must be periodically renewed, it is implied that the world of play is not completely self-sufficient. In searching for fellow players, it is recognized that this periodically renewed contact with the world involves some element of interpersonal relationships. An adequate development of Nietzsche's category of play must take these two problems into account, supplementing the category of the creative play of the child with a mediating structure by means of which it can remain in contact with the non-play world if one assumes the existence of such a world. The Free Spirit

The second major text to be considered here is the Preface to Human, AlZ-too-human, which was written in the spring of 1886 for a new edition of that work. Thus it comes about three years after the section on "The Three Metamorphoses" in Thus Spoke Zarathustra. It is to be grouped together with several other new prefaces (for The Birth of Tragedy, Human, AZZ-too-human II, The Dawn, and The Joyful Wisdom), Book Five of The Joyful Wisdom, Beyond Good and Evil, and On the Genealogy of Morals. In these writings, the section which adds the most to our understanding of the free spirit is Section Two of Bewond Good and Evil. A1though I am not taking this 
text as the explicit point of reference in this section, I shall draw upon it freely to expand upon the idea of the development of the free spirit found in the 1886 Preface to Human, All-too-human, I. Taken together, these writings provide another model for understanding the development of the spirit, "in which the type 'free spirit' will sometime become ripe and sweet to perfection."19

In this section, I shall first show that there are six separable moments in the development of the free spirit: (1) the fettered spirit, which forms the starting-point; (2) the great breakingloose; (3) the bird's Ereedom; (4) the great health; (5) the emergence of self-awareness; and (6) the generalization of the free spirit's self-awareness into the problem of the order of rank. It will be shown that the highest form of activity in this process of development is an activity which corresponds to the category of play developed in the preceding analysis of "The Three Metamorphoses." Finally, it will be shown that this type of playing involves the doctrine of the order of rank, suggesting that the creative play which is Nietzsche's highest activity is not a completely arbitrary play, that rules of this play may be understood in relation to the order of rank--a hypothesis whose validity will be tested in the section which follows.

19Menschliches, Allzumenschliches, I, "Vorrede," 3, in Nietzsche Werke, Vierte Abteilung, Zweiter Band (Berlin: Walter de Gruyter, 1967), p. 9. ". . . in dem der Typus 'freier Geist' einmal bis zur Vollkommenheit reif und süss werden soll . . " Hereafter abbreviated as MA, I. 
The fettered spirit is the starting-point: a man of a high and select type, but who is chained down by duties, a spirit whose "highest moments themselves will bind them the most strongly, obligate them the longest." 20 The element of duty calls attention to the similarities between the fettered spirit and the camel: both are out of the ordinary (spirits, not mere members of the herd), both are still under the influence of the "thou shalt," both contain within themselves the possibility of self-overcoming. This is the attitude of youth, with its wrathful and reverent attitudes that themselves contain an element of forgery and deception. 21

The great breaking-loose is the decisive event which marks the start of the spirit's journey toward liberation. It "comes... sudden1y, like an earthquake,"22 and the person "doesn't understand what is happening." 23 Here the spirit has much less control over the situation than the lion does in Zarathustra. This reflects a shift of emphasis in the description from an ideal viewpoint in the

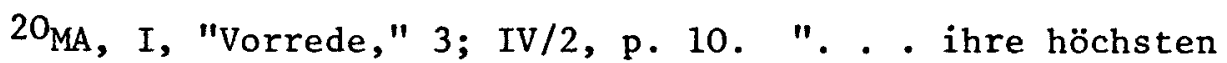
Augenblicke selbst werden sie am festesten binden, am dauerndsten verphlichten."

${ }^{21}$ Cf. Jenseits von Gut und Böse, II, in Nietzsche Werke, Sechste Abteilung, Zweiter Band (Berlin: Walter de Gruyter, 1968), p. 45 = Beyond Good and Evil, translated by Walter Kaufmann (New York: Random House, 1966), p. 43. Hereafter abbreviated as JGB and BGE respectively.

22MA, I, "Vorrede," 3; IV/2, p. 10. "Die grosse Los1ösung kommt . . plötzlich, wie ein Erdstoss..."

${ }^{23}$ Ibid. ". . die junge Seele.. selbst versteht nicht, was sich begiebt." 
three metamorphoses to a more concrete standpoint here. The great breaking-loose is characterized by a desire to go away, anywhere, a contempt for what has been called duty, accompanied by "a turbulent, willful, erupting longing for wandering, strangeness, alienation, cold, disenchantment, congelation . . ."24 What unites these characteristics is that they all represent a great breakino-1onse from all previous bonds and a willful going beyond oneself to what had previously been forbidden or revolting.

This second stage is both a victorv and a sickness from which the soirit will eventually recover. It is a victory because of what makes its first appearance here: "this first outbreak of force and the will to self-determination. setting one's own values. this will to the free will."25 This freedom and breaking-loose closely parallel the stage of the 1ion in "The Three Metamorphoses," the free spirit being seduced further and further away from the familiar and toward the great loneliness. A fragment from Nietzsche's notebooks indicates that he considered himself to be passing through this stage while he was writing Human, AZZ-too-human--"a strange and evil game."26

${ }^{24} \mathrm{Ibid.} \mathrm{".} \mathrm{.} \mathrm{.} \mathrm{ein} \mathrm{aufrührerisches,} \mathrm{willkürliches,} \mathrm{vulkanisch}$ stossendes Verlangen nach Wanderschaft, Fremde, Entfremdung, Erkältung, Ernüchterung, Vereisung . . ."

${ }^{25}$ Ibid., pp. 10-11. ". . . dieser erste Ausbruch von Kraft und Willen zur Selbstbestimmung, Selbst-Werthsetzung, dieser Wille zum freien Willen."

Spiel . . ." ${ }^{26}$ UW, I, $\$ 1298$, p. 405. ". . . ein unheimliches und böses 
The bird's freedom is a middle state between the great breaking-loose and the great health, a long period of convalescence characterized by a tough Will to Health, which disguises itself at times as health itself. It is in this period of convalescence that the bird's freedom appears: "a feeling of the freedom of the bird, its vision, its high spirits, a third something in which curiosity and tender contempt are bound together." 27 The free spirit emerges, and his existence is characterized by a peculiar detachment, living without "yes," without "no." This state is one step closer to the child, to the great health, but still lacking the creative affirmation of the child's play. Indeed, it is clear that the highest form of human activity for Nietzsche is not an arbitrary, capricious play - it might be possible to interpret the bird's freedom in this manner --but something more, since the development, of the spirit does not end with this stage.

The great health comes only gradually, in small doses, and allows the free spirit to draw nearer to life. The very image of the flying bird suggests the instability of the previous state: it must eventually descend and land. In so doing, he discovers for the first time what is near; at the same time he is able to see himself for the first time. Seeing himself became possible only after he had

$27_{\mathrm{MA}}$, I, "Vorrede," 4; IV/2, p. 12. ". . . ein Gefüh1 von Voge1-Freiheit, Voge1-Umb1ick, Voge1-Uebermuth, etwas Drittes, in dem sich Neugierde und zarte Verachtung gebunden haben." 
gone beyond himself, had literally been outside of himself. He must become alienated from himself in order to come to know himself, and it is sickness which brings about this alienation. The sickness that the free spirit undergoes is then the door through which it must pass in order to reach health, "that monstrous, overflowing safety and health, which itself cannot dispense with sickness as a means and a fishhook." 28

This great health is characterized by overflowing, superabundance, various and opposite ways of thinking, and "the right to live experimentally."29 It is in living experimentally that one reaches the state comparable to that of the child in Thus Spoke Zarathustra. In Beyond Good and Evil those who reach this state are called "Versucher," which could be translated variously as "attempters," "tempters," or "experimenters." 30 It is important to note that living experimentally comes after the spirit has come back down to earth, drawn nearer to life. The activity of the free spirit who has achieved the great health is one which takes place in the wor1d.

${ }^{28}$ Ibid., p. 11. ". . . jener ungeheuren überströmenden Sicherheit und Gesundheit, welche der Krankheit selbst nicht entrathen mag, als eines Mittels und Angelhakens der Erkenntniss . . ."

${ }^{29}$ Ibid., p. 12. ". . . auf den Versuch hin leben."

${ }^{30} \mathrm{JGB}$, II, $\$ 42$; VI/2, p. $55=\mathrm{BGE}$, II, \$42, p. 52. As Nietzsche sees it, "möchten diese Philosophen der Zukunft ein Recht, vielleicht auch ein Unrecht darauf haben, als Versucher bezeichnet zu werden. Dieser Name selbst ist zuletzt nur ein Versuch, und, wenn man will, eine Versuchung." 
The play character of the great health is emphasized in Book Five of The Joyful Wisdom, written at about the same time as the Preface to Human, AZZ-too-human. In a section entitled "The Great Health," Nietzsche describes the ideal of human activity as play. Another ideal runs on before us, a strange, tempting ideal, full of danger, to which we should not like to persuade any one, because we do not so readily acknowledge any one's right thereto: the ideal of a spirit who plays naively (that is to say involuntarily and from overflowing abundance and power) with everything that has hitherto been called holy, good, inviolable, divine.. 31

Play is the proper activity of the free spirit when he has achieved the great health, and this play takes place after the descent of the free spirit from the heights of the bird's freedom.

Self-cwareness develops as the free spirit begins to realize what has happened to him; this is when "the puzzle of that great breaking-loose. . may begin to unveil itself."32 Here his consciousness of himself as a master develops: a master for whom all of existence--not only things, but also values and reasons--become tools at his service, toys that he can play with. True perspectivism, not

${ }^{31}$ Friedrich Nietzsche, Die fröhliche Wissenschaft, mit einem Nachwort von Alfred Baeumler (Stuttgart: Alfred Kröner, 1965), Fifth Book, $\$ 382$, p. $302=$ The Joyful Wisdom, translated by Thomas Common (New York: Frederick Ungar, 1960), p. 352. "Ein anderes Ideal läuft vor uns her, ein wunderliches, versucherisches, gefahrenreiches Ideal, zu dem wir niemanden überreden möchten, weil wir niemandem so leicht das Recht darauf zugestehen: das Ideal eines Geistes, der naiv, das heißt ungewollt und aus überströmender Fülle und Mächtigkeit mit allem spielt, was bisher heilig, gut, unberührbar, göttlich hieß.. . " Hereafter these works are abbreviated as FW and JW respectively.

32MA, I, "Vorrede," 6; IV/2, p. 14. ". . . sich das Rätsel jener grossen Loslösung zu entschleiern beginnt." 
only in thought but also in action (for this involves living experimentally, not just thinking freely ${ }^{33}$ ) comes to fruition here. The free spirit gains power over al1 his "for's" and "against's," learns to play with them and use them to his own higher purposes. He sees the necessary injustice in every "for" and "against," sees "injustice as inseparable from life, life itself as conditioned through the perspectival and its injustice." 34 Injustice is to be found in particular there where life is least developed, most narrow, where it nonetheless cannot refrain from taking itself as the purpose and measure of things. 35 Although the free spirit also lives perspectivally, his perspectivism differs from that which is normally encountered, for he realizes that it is a perspective, assumed for the sake of the experiment of life, nothing more.

The category of play lies at the heart of this notion of perspectivism and this idea of life as an experiment. In gaining power over one's "for's" and "against's," one realizes that there is no essential opposition between "true" and "false," that it is rather a question of degrees of appearance, that it is a moral prejudice to

${ }^{33}$ The emphasis on action is suggested in Nietzsche's distinction between the "free thinkers" and the "free spirits;" see JGB, II, $\$ 44 ; \mathrm{VI} / 2, \mathrm{p} .58=\mathrm{BGE}, \mathrm{II}, \$ 44, \mathrm{p} .55$. It is made explicit in $\mathrm{FW}, \mathrm{V}$, $\S 372$, p. $288=\mathrm{JW}, \mathrm{V}, \S 372$, p. 336 .

${ }^{34} \mathrm{MA}, \mathrm{I}$, "Vorrede," 6; IV/2, p. 14. ". . . die Ungerechtigkeit als unablösbar vom Leben, das Leben selbst als bedingt durch das Perspektivische und seine Ungerechtigkeit."

${ }^{35}$ Ibid. 
assume that truth is worth more than mere appearance. 36 When this line of thinking is carried to its final conclusion, one realizes that there are only interpretations. 37 The doctrine of perspectivism implies that everything is really nothing more than a plaything, lacking any nature in itself which would give it a "true" meaning. To live experimentally is, then, "to dance even on the verge of the abysses," 38 to play creatively when one is on the verge of realizing that there is only play. This is the activity of the free spirit par excezzence.

The doctrine of the order of rank is the highest expression of the growing self-awareness of the free spirit; it grows out of the insight that "power and right and the scope of perspective grow higher with one another."39 In this final step he generalizes his case. "'The way it works out for me,' he tells himself, 'is the way it must work out for everyone in whom a task becomes incarnate and will "come into the world". "140 The problem of the order of

$$
\begin{aligned}
& 36 \mathrm{JGB}, \mathrm{II}, \S 34 ; \mathrm{VI} / 2, \mathrm{p} .49=\mathrm{BGE}, \mathrm{II}, \S 34, \mathrm{p} .46 . \\
& 37_{\mathrm{JGB}} \mathrm{I}, \S 22 ; \mathrm{VI} / 2, \mathrm{p} .31=\mathrm{BGE}, \mathrm{I}, \S 22, \mathrm{p} .30 \\
& 38_{\mathrm{FW}} \mathrm{V}, \S 347, \mathrm{p} .245=\mathrm{JW}, \mathrm{V}, \S 347, \mathrm{p} .287 . \text { ". . . selbst }
\end{aligned}
$$
an Abgründen noch zu tanzen. Ein solcher Geist wäre der freie Geist par excellence."

39 MA, I, "Vorrede," 6; IV/2, pp. 14-15. ". . . Macht und Recht und Umfänglichkeit der Perspektive mit einander in die Höhe wachsen."

40 MA, I, "Vorrede," 7; IV/2, p. 15. "Wie es mir ergieng, sagt er sich, muss es Jedem ergehn, in dem eine Aufgabe leibhaft werden und 'zur We1t kommen' wi11." 
rank defines the free spirits and their task, and it is this problem which has guided their development, even when they did not know it. 41 Although a detailed discussion of the doctrine of the order of rank is given in the next section of this chapter, a preliminary interpretation can be set forth here in regard to this question: how is the order of rank a task for the free spirit? Insofar as the free spirit realizes that all of existence is perspectival, insofar as he realizes that it is the result of creative activity which is fundamentally play, he sees the order of rank as a task in this sense: he must gain power over his "for's" and "against's," over his purposes, over his perspectives. In other words, he must create the order of rank--that is the task of the free spirit. Realizing that this is his task, he knows that the meaning and order of his world are the result of his creative play. That there must be some order of rank is a recognition of the necessity of rules and structure in play. The free spirit's realization that the creation of the order of rank is his task implies his awareness of himself as a creative player whose activity results in the appearance of new worlds.

This preliminary interpretation of the doctrine of the order of rank in relation to the creative play of the free spirit provides the foundation for a refinement of the distinction between the play world and the non-play worlds. The realization that everything is interpretation and the awareness of the order of rank as his task 
gives the free spirit the basis for concluding that his play world is but one such world among many--that there are only play worlds, no "real world." They define themselves in relation to each other, and there is no need to assume the opposite of a play world. Rather than saying that the child's play must return to the world, it would be more precise to say that this creative play must continually seek to enlarge its boundaries, to extend its influence. The need for creative play to extend its influence is equivalent to the free spirit's realization that the order of rank is its proper task and is consistent, as will be shown later, with the general tendency of the will to power to extend its boundaries, maximize its effects. This investigation of the category of play in relation to the free spirit and his development again underscores the fact that this kind of creative play is possible only for the few. Only a high and select type enter upon the process of the liberation of the spirit, and even these few have no guarantee of final success. Moreover, the free spirit himself is not consciously directing this process. Reaching the stage where one can play creatively is itself an achievement. It has also been shown that the proper task of the free spirit is playing, creating the order of rank and thereby. impressing on the other play worlds the character of the free spirit's play. This play is not an arbitrary activity. For the free spirit, it is related to a very specific task: the creation of a new order of rank. This is the creative play of the Versucher, who realize that the world itself is but a multiplicity of play worlds, none of 
which have any claim to being absolutely true.

Given this preliminary analysis, we now have to turn to a more detailed consideration of the order of rank, seeking to discover what specific bounds it imposes upon the creative play of the free spirits.

The Order of Rank

It is the order of rank which gives content to Nietzsche's idea of the free spirit, and its importance for an understanding of his notion of human activity as play is clear. Nietzsche identifies his own philosophy with teaching the order of rank, ${ }^{42}$ arguing that this must be re-established to counteract the growing emphasis on equality 43 and to prevent the extension of the values of the herd to those who are outside the herd. 44

In this section dealing with the doctrine of the order of rank, it will be shown that previous explanations of the orderliness and purposefulness of human existence can be understood as examples of the order of rank. In the past these have of ten been taken to be something more than, or other than the order of rank. They have, for example, been taken to be expressions of an absolute order and purpose

42 UW, II, $\$ 1411$, p. 508.

43Friedrich Nietzsche, Der Wille zur Macht (Stuttgart: Alfred Kröner Verlag, 1964), \$854, p. $581=$ The Will to Power, translated by Walter Kaufmann and R. J. Hollingdale (New York: Random House, 1967), p. 457. Hereafter abbreviated as WM and WP respectively.

$$
44 \mathrm{WM}, \$ 287, \text { p. } 203=\mathrm{WP}, \$ 287, \text { p. } 162 .
$$


in nature itself, rather than being seen as an expression of man's creative play. The various orders of rank are not, however, absolute, but rather on-going, developing, as indeed existence itself is. They are, like all games, finite expressions of man's creativity, limited and changing.

It will be shown, furthermore, that the doctrine of the order of rank has a two-fold meaning. It is both an analytical tool in terms of which past orders of rank may be analyzed and also, as has already been seen, a task for the free spirits. These two notions come together in the idea of interpretation as creative play, the first being play with the past, the second being play with the future. Finally, an analysis of the criteria for determining the order of rank will be shown to give an insight into the specific character of play, the way in which play is power, the will to power created by the overman. This gives us an insight into the essential unity of Nietzsche's thought and suggests a possible way of overcoming the traditional opposition between freedom and necessity in the category of creative play. Thus it will be shown that the doctrine od the order of rank is an expression of the orderliness proper to the creative play of the free spirits.

The primary function of the doctrine of the order of rank as an analytical tool is that it allows one to confront and deal with traditional moral problems and divisions on a non-moral basis. The conflict between the "true world" uncovered by pessimism and "a world possible for life" must be seen as a struggle of one kind of life 
("sickly, despairing life that cleaves to a beyond") with another kind ("healthier, more stupid and mendacious, richer, less degenerate life"), not as a struggle between "truth" and life. This problem can only be resolved in terms of an order of rank: "Here one must demonstrate the need for an order of rank--that the first problem is the order of rank of different kinds of life." 45 By rejecting an interpretation of this conflict as one between "truth" and life, Nietzsche is following his own suggestion in Beyond Good and Eviz to forgo interpretations in terms of "true" and "false" and to deal instead with "degrees of apparentness."46 One of the essential characteristics of the order of rank is that it overcomes one of the traditional prejudices of philosophers, the faith in opposite values. It does this by realizing that there are many created worlds, play worlds, some of which are more powerful than others, but all of which still remain as created worlds.

This demonstration of the necessity of an order of rank is possible if one can show (1) the insufficiency of all previous divisions, especially the moral one, and (2) the way in which the order of rank is grounded in life itself. The first part of this task

$45 \mathrm{WM}, \$ 592$, p. $411=\mathrm{WP}, \$ 592$, p. 324. "Hier muß die Beweisführung einsetzen, daß eine Rangordnung not tut,--daß das erste Problem das der Rangordnung der Axten Leben ist."

$$
46 \mathrm{JGB}, \mathrm{II}, \$ 34 ; \mathrm{VI} / 2, \mathrm{p} .49=\mathrm{BGE}, \mathrm{II}, \$ 34, \mathrm{p} .46 . " \mathrm{Ja},
$$
was zwingt uns überhaupt zur Annahme, dass es einen wesenhaften Gegensatz von 'wahr' und 'falsch' giebt? Genügt es nicht, Stufen der Scheinbarkeit anzunehmen . . . ?" 
is accomplished primarily by means of a reduction of previous divisions of the order of rank. First, and most important, morality must be shown to be only another version of the order of rank in disguise.

Morality is the doctrine of the order of rank of men, and consequently also of the meaningfulness of their actions and works for this order of rank: thus the doctrine of human value judgments in relation to everything human. Most moral philosophers present only the contemporary ruling order of rank; on the one hand, a lack of historical sense,-on the other, they themselves are ruled by the morality, which the present teaches as eternallyvalid. 47

Thus the order of rank has an historical dimension not usually found in morality, and one can infer from the description above that the one who holds the order of rank would be able to go beyond the distortions of morality which mistakes the present for the eternallyvalid. Thus moralities are reducible to "the expression of locally limited orders of rank." 48

Insofar as one is concerned with morality instead of the order of rank, one would be--in Nietzsche's order of rank--in a rank below that of the free spirit. One's perspectives would be narrowed, confined by the limits of a particular morality. One would not have

47 UW, II, \$675, p. 213. "Moral ist die Lehre von der Rangordnung der Menschen, und folglich auch von der Bedeutsamkeit ihrer Handlungen und Werke für diese Rangordnung: also die Lehre von den menschlichen Wertschätzungen in betreff alles Menschlichen. Die meisten Moralphilosophen stellen nur die gegerwärtige herrschende Rangordnung dar; Mangel an historischem Sinn einerseits,--anderseits sie werden selber von der Moral beherrscht, welche das Gegenwärtige als das Ewig-Gültige lehrt."

$48 \mathrm{WM}, \$ 966$, p. $644=\mathrm{WP}, \$ 966$, p. 507. "Moralen sind der Ausdruck lokal beschränkter Rangordnungen in dieser vielfachen Welt der Triebe." 
realized that morality is also a human creation. One would be lacking in the instinct for privilege, distance, the feeling of creative natures which characterize the higher reaches of the order of rank. 49 The superiority of the doctrine of the order of rank as a source of meaning and order in the world in contrast to morality consists in the fact that it allows all this: the widening of perspectives, the realization of the role of human creativity in the development of this meaning and order, the instinct for privilege, distance, and the other qualities of the free spirit.

other phenomena can also be understood more adequately in terms of the order of rank. It will suffice to call attention to just one here: religion. It is "essentially a doctrine of the order of rank, even an attempt at a cosmic order of rank and of power."50 Approaching religion as a manifestation of the order of rank allows Nietzsche to make sense of its appearance without giving to it the validity it would claim for itself. The existence of religion is not denied, but its own interpretation of its significance is questioned.

${ }^{49} \mathrm{WM}, \$ 879$, p. $598=\mathrm{WP}, \$ 879$, p. $470=$ NachgeZassene Fragmente. Herbst 1887 bis März 1888 in Nietzsche Werke, Achte Abteilung, Zweiter Band (Berlin: Walter de Gruyter, 1970), 9(152), p. 88. Hereafter the Nachgelassene Fragmente will be abbreviated as $\mathrm{NF}$, followed by the part and volume numbers, then the notebook number, and fina1ly the page number. Thus: NF, VIII/2, 9(152), p. 88.

50 UW, II, \$846, p. 291. "Religion--wesent1ich Lehre der Rangordnung, sogar Versuch einer kosmischen Rang- und Machtordnung." 
The task of creating one's own order of rank, the principle which dominates the creative play of the free spirit, is clearly not to be understood as a moral imperative, as a fragment from Nietzsche's notebooks shows.

An imperative, "conduct yourself in accord with the order of rank that you belong to," is senseless: because we would have to know (1) ourselves and (2) that order, neither of which is the case,--and (3) because it is superfluous to order something which would occur anyway. 51

It is questionable how much weight should be put on this fragment, since Nietzsche did not include it in any of the works he published. While it would be possible to interpret it in such a way as to suggest that the order of rank is something beyond our control, a necessity imposed upon us, it is more in line with Nietzsche's thinking to read this fragment in conjunction with his three-stage history of morals in Beyond Good and Eviz. In pre-historical times the value of an action was judged on the basis of its consequences. In the last ten thousand years, the origin of the action became the decisive factor. In the third stage, represented by the immoralists, - . the decisive value of an action lies precisely in what is unintentional in it, while everything about it that is intentional, everything about it that can be seen, known, "conscious," still belongs to its surface and skin . . .52

$51_{U W,}$ II, $\$ 757$, p. 246. "Ein Imperativ, 'benimm dich der Rangordnung gemäß, zu der du gehörst, ist unsinnig, weil wir 1 . uns, 2. jene Ordnung kennen müssten, was beides nicht der Fal1 ist,--und 3. weil es überflüssig ist, etwas zu befehlen, das ohnedies geschieht."

${ }^{52} \mathrm{JGB}, \mathrm{II}, \S 32$; VI/2, p. $47=\mathrm{BGE}, \mathrm{II}, \S 32, \mathrm{p} .44$. ". . . gerade in dem, was nicht-absichtlich an einer Handlung ist, ihr entscheidener Werth belegen sei, und dass alle ihre Absichtlichkeit, was von ihr gesehn, gewusst, 'bewusst' werden kann, noch zu ihrer oberfläche und Haut gehöre..." 
While a thorough treatment of this theme must await the material presented in the next two chapters, it can be indicated in a preliminary way that the order of rank is not an imperative, nor is it an abstract idea, but rather an expression of the totality of one's being. One cannot be commanded to act according to it, for no other alternative is possible. It is what we make it to be. It is for this reason that we cannot know the order of rank: as our creation, much of it is intentiona1, but perhaps the most significant part of it remains unintentional. There is implied in this position a notion of human action as stemming from the entire self, not just thought, which will be considered in detail in Chapter Five.

There are numerous other formulations of the order of rank, a number of which are to be found in Nietzsche's notebooks. It is possible here to call attention to only a few of these, but they will serve to point out the two-fold sense in which the idea of the order of rank is used. In the face of skepticism growing out of the nineteenth-century historical sense, Nietzsche asserts the existence of an order of rank of both men and problems. 53 Elsewhere he writes of posing the question of the order of rank of artists in a new way, distinguishing between artists who are dominated by major intellectual movements and those where the artist is only a part of the man, as in the case of Plato, Goethe, and Giordano Bruno. 54 A short fragment

$$
\begin{aligned}
& { }^{53} \mathrm{UW}, \mathrm{I}, \$ 563, \text { p. } 214 . \\
& { }^{54} \mathrm{UW}, \mathrm{I}, \$ 538, \text { p. } 202 .
\end{aligned}
$$


refers to a new order of rank for spirits in which the tragic natures are no longer dominant. 55 The crisis precipitated by nihilism results in a process of purification, promoting "an order of rank of strengths [forces] from the viewpoint of health."56 An order of rank of goods according to the degree of egoism is presented in Human, AZZ-too-human, and Nietzsche acknowledges that this order of rank can change. 57 Although after each such change specific actions become designated as moral or immoral, the principle of change is not morality itself. 58 The order of rank is prior to, and more fundamental than morality.

Two different usages of the notion of the order of rank can be distinguished in these and other passages. First, it is used as a descriptive term in relation to past and present phenomena which lays bare their true structure. Thus morality, religion and art are to be understood first and foremost in terms of the way in which they express the dominant order of rank. Second, the idea is used to point the way toward the creation of a new order of rank. In addition to the passages cited above, one can call attention to a fragment in the notebooks where Nietzsche asserts that, with the transvaluation of all values, the principle of the order of rank of all

$55 \mathrm{WM}, \S 992$, p. $655=\mathrm{WP}, \S 992$, p. 517 .

56 WM, $\$ 55$, p. $48=W P, \S 55$, p. 38. ". . . einer Rangordnung der Kräfte, vom Gesichtspunkt der Gesundheit . . ."

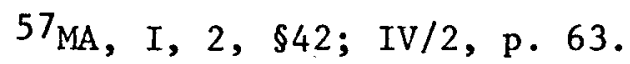

${ }^{58}$ Ibid. 
values is inverted. 59 So, too, the immoralists are engaged in the task of creating a new order of rank insofar as they are reversing the traditional relation between, on the one hand, priests and other teachers of a beyond and, on the other hand, the blasphemers and other immoralists. 60 These two diverging notions of the order of rank begin to merge when Nietzsche takes this second usage and applies it to historical instances, creating a new order of rank in the past. By interpreting history, one creates new orders of rank. Thus what might have appeared at first to have been a fixed order of rank in the past is changing in two senses. First, the order of rank itself changes in the course of history through the creative actions of men, especially of the powerful ones. Second, in interpreting this past development, new orders of rank are created through the power of the interpretation as an exercise of the will to power. Both of these are play activity. In the past, the creative play of the powerful creates orders of rank, transforms old ones. In the present, one plays with the past, creating out of the manifold possibilities it offers new orders of rank, which in turn creates an openness for the future.

The principle governing the order of rank is clearly power: ". . what determines rank, sets off rank, is only quanta of power; p. 173 .

$$
59 \mathrm{WM}, \S 1006, \text { p. } 661=\mathrm{WP}, \$ 1006, \text { p. } 521=\mathrm{NF}, \operatorname{VIII} / 2,9(66) \text {, }
$$$$
60_{\mathrm{WM}} \S 116, \mathrm{p} .84=\mathrm{WP}, \S 116, \mathrm{p} .71=\mathrm{NF}, \operatorname{VIII} / 2,15(44) \text {, }
$$
p. 232 . 
and nothing else."61 It is on this basis that the two fundamental types of life can be distinguished:

I distinguish between a type of ascending life and another type of decay, disintegration, weakness.

Is it credible that the question of the relative rank of these two types still needs to be posed.62

Clearly there is no question in Nietzsche's mind: ascending life is superior to decaying, disintegrating life. Since ascending life is basically life that is increasing its own power and extending its boundaries, it is also clear that this ascending life is fundamentally the will to power which is increasing. It is not ascending toward some goal which exists outside of itself, but rather ascending toward more and more power, greater and greater dominance. As it reaches its highest point, we encounter "here and there, a completely Epicurean god, the overman, the redeemer of existence."63 The order of rank is the highest expression of the creative play of man, the most powerful expression of created order and purpose. The notion of ascending life indicates that this creative play is seeking continually to extend the boundaries of its play world.

$61_{\mathrm{WM}} \$ 854$, p. $581=\mathrm{WP}, \$ 854$, p. 482. "Rangbestimmend, Rang abhebend sind allein Macht-Quantitäten: und sonst nichts."

$$
62 \mathrm{WM}, \$ 857, \text { p. } 581=\mathrm{WP}, \$ 857, \text { p. } 457=\mathrm{NF}, \mathrm{VIII} / 3,15(120) \text {, }
$$
p. 275. "Ich unterscheide einen Typus des aufsteigenden Lebens und einen anderen des Verfalls, der Zersetzung, der Schwäche.

"So11te man glauben, daß die Rangfrage zwischen beiden Typen überhaupt noch zu stellen ist? . . ."

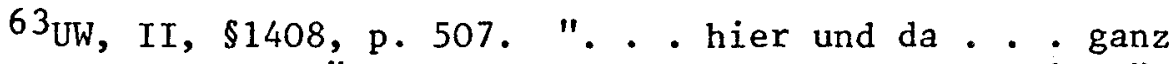
epikurischer Gott, der Übermensch, der Verk1ärer des Daseins." 
Thus the order of rank is the result of the creative play of the powerful who, in the fullness of their power, give a new order to the world--indeed, create a new world in both thought and action. They reinterpret the past, creating new orders of rank through their playful thinking, through the power of their thinking. They create a new order of rank in the present by means of all their actions, preparing the way for a future in which the overman can emerge. Their play is founded in their will to power and, at the same time, gives full expression to that will to power by establishing the order of rank--which is based in power--as the order of the world. They do this by extending the boundaries of their own play world, by taking over and transforming other worlds which themselves were the result of previous instances of such creative play.

There remains one final qualification which should be noted in this description. Throughout this analysis, the free spirit and the overman have been referred to in such a way as to suggest that they are isolated individuals. In a fragment in his notebooks, Nietasche seeks to refine this view by extending his notion of the multiplicity of forces in such a way as to call into question the concept of an "individual."

That man is a multiplicity of forces, which stand in an order of rank: so that there are those who give the orders, but they must also create everything that is necessary for the survival of those who obey; thus they are conditioned through the existence of those who obey. A11 these living beings must be of a related type, otherwise they could not serve and obey each other so: the servants must, in some sense, be those who obey also, and in finer cases the role must change between them; the one who otherwise orders must obey. The concept "individual" is wrong. These beings are not present in an isolated manner; 
the main point of importance is something changeable; the continual creation of cells, etc. yields a continual change in the number of these beings. 64

Although this is a problem which will be discussed in depth in Chapter Five, it is important to point out here that this creative play that brings about a new order of rank is itself founded in a more fundamental type of play: the interplay of this multiplicity of forces which is constitutive of the will to power. Concluding Remarks on the Ideal of Creative Play

In the three preceding sections of this chapter the foundation for a Nietzschean philosophy of play has been laid. It has been established, first of all, that the category of play is one in terms of which the creative activity of the child in "The Three Metamorphoses" and that of the free spirit is to be understood. It has been further established that the doctrine of the order of rank is the expression of the order which such play creates: not an absolute, unchanging order, but rather an order of becoming. Suggestions were made that the will to power is itself this creative play

${ }^{64} \mathrm{UW}, \mathrm{II}, \$ 734$, p. 237. "Daß der Mensch eine Vielheit von Kräften ist, welche in einer Rangordnung stehen: so, daß es Befehlende gibt, aber daß auch der Befehlende den Gehorchenden alles schaffen muß, was zu ihrer Erhaltung dient, somit selber durch deren Existenz bedingt ist. Alle diese lebendigen Wesen müssen verwandter Art sein, sonst könnten sie nicht so einander dienen und gehorchen: die Dienenden müssen, in irgend einem Sinne, auch Gehorchende sein, und in feineren Fällen muß die Rolle zwischen ihnen vorübergehend wechseln, und der, welcher sonst befieh1t, einmal gehorchen. Der Begriff 'individuum' ist falsch. Diese Wesen sind isoliert gar nicht vorhanden: das zentrale Schwergewicht ist etwas Wandelbares ; das fortwährende Erzeugen von Zellen usw. gibt einen fortwährenden Wandel der Zahl dieser Wesen." 
and these will be developed in Chapter Four. It has at least been established that the foundation of this creative play is power, and that the extension of this power--the attempt to maximize it--involves the expansion of the play world of the free spirit.

By thinking through the problem of the order of rank in terms of creative play, it is possible to follow Nietzsche's suggestion that we think in terms of degrees of appearance rather than in opposites. Reality becomes a multiplicity of play worlds, the more powerful ones dominating the less powerful. The creation of an order of rank by the free spirit imprints the play character of existence on the world in both a specific and a general sense. In the specific sense, the free spirit makes his particular play real through $h$ is creative activity. In the general sense, all creations of orders of rank reaffirm the basic quality of human activity as play and of existence as the plaything of the powerful.

To what extent is this creative play arbitrary? It is not arbitrary in two senses. First, its appearance is not something that just happens, but rather the culmination of a long process of development of the person's entire being. In this sense, to begin to play creatively is not an arbitrary occurrence. Second, play is not mere capricious activity--it necessarily involves the creation of order. The question is whether there is a third sense in which the specific order that one creates is something other than arbitrarv. In other words, granting that play must create order, is it completely free to create any order? 
I would maintain that Nietzsche thought that there were limits, that creative play did know some boundaries. Perhaps the best example of what those limits would be is the series of "thou shalt's" which Nietzsche addresses to the free spirit in the 1886 Preface to Human, All-too-human.

Thou shalt become master over thyself, master also over your own virtues . . . Thou shalt gain control over your "for" and "against" . . Thou shalt learn to comprehend the perspectival in every evaluation. . . Thou shalt learn to comprehend the necessary injustice in every "for" and "against," injustice inseparable from life, life itself as conditioned through the perspectival and its injustice. Thou shalt above all clearly see where the injustice is always greatest: namely there, where life is smallest, narrowest, neediest, most recently developed and yet cannot refrain from taking itself as the purpose and measure of things . . . Thou shalt see the problem of the order of rank clearly and see how power and right and scope of perspective grow higher with one another. 65

It is clear from this passage, which could be supplemented by numerous other exhortatory passages throughout. Nietzsche's writings, that this creative play is not completely arbitrary, but rather stands under very definite rules. However, these rules spring, not

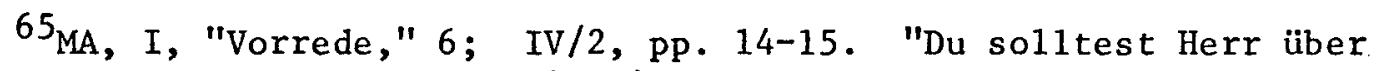
dich werden, Herr auch über die eigenen Tugenden. . . . Du solltest Gewalt über dein Für und Wider bekommen . . . Du solltest die nothwendige Ungerechtigkeit in jedem Für und Wider begreifen lernen, die Ungerechtigkeit als unablösbar vom Leben, das Leben selbst als bedingt durch das Perspektivische und seine Ungerechtigkeit. Du solltest vor Allem mit Augen sehn, wo die Ungerechtigkeit immer am grössten ist: dort nämlich, wo das Leben am kleinsten, engsten, dürftigsten, anfänglichsten entwickelt ist und dennoch nicht umhin kann, sich als Zweck und Maass der Dinge zu nehmen . . du solltest das Problem der Rangordnung mit Augen sehn und wie Macht und Recht und Umfänglichkeit der Perspektive mit einander in die Höhe wachsen." 
from any external source, but from the free spirit himself.

". . Thou shalt"--enough, the free spirit knows by this time which "thou shalt's" he has obeyed, and also what he now can do, what he for the first time--may do . . .66

The foundation of these "thou shalt's" is in the activity of the free spirit. In order to play freely and creatively, one must have control over the game, over the "for's" and "against's." One must realize the self-delusion on the part of those who mistake their own narrow perspectives for the purpose and measure of things, as if their play were equivalent to reality itself. Finally, one must realize that one's own creative play brings about an order of rank which seeks continually to extend its power and scope to more and more of existence. The consummation of this creative play is to be found in making all the other play worlds into your play world.

\section{B. Nihilism and the Necessity of Play}

\section{Introduction}

The first part of this chapter has been concerned with showing that the highest form of human activity for Nietzsche was play. That part of the analysis was concerned with Nietzsche's ideas about the creative play of the child, the free spirit, and the order of rank. These may all be classed as positive descriptions of ideal forms of human activity.

66Ibid., p. 15. "'. . Du solltest'--genug, der freie Geist weiss nunmehr, welchem 'du sollst' er gehorcht hat, und auch, was er jetzt kann, was er jetzt erst--darf. . ." 
There remains a second way in which play emerges as the highest form of human activity, and this can be termed a negative one. It is rooted in Nietzsche's analysis of nihilism. In this chapter I shall conclude the analysis of play as a form of human activity by showing that the only type of meaningful human activity possible after the experience of nihilism is play. It is in play that man becomes able to overcome nihilism. Insofar as nihilism is the necessary startingpoint of contemporary man, play becomes the only way in which man can achieve self-overcoming.

The Necessity of Nihilism

The experience of nihilism functions as a gateway into the contemporary world for Nietzsche--indeed, more than a gateway: a corridor two centuries long through which mankind must pass, 67 one which we still find ourselves in today. 68 Historically considered, nihilism is the culminating moment of the breakdown of the Christian moral interpretation of the world which characterized the nineteenth century. 69 It is a necessary experience for contemporary man precisely

$67_{\mathrm{WM}}$, "Vorrede," $2, \mathrm{p} .3=\mathrm{WP}$, Preface, $2, \mathrm{p} .3=\mathrm{NF}, \mathrm{VIII} / 2$, $11(411)$, p. 431 .

${ }^{68}$ On the contemporary dimensions of the problem of nihilism, see Helmuth Thielicke, Nihilism, with an Introduction by Michael Novak (New York: Schocken Books, 1969); Stanley Rosen, Nihilism. A Philosophical Essay (New Haven: Yale University Press, 1969); Michae1 Novak, The Experience of Nothingness (New York: Harper and Row, 1970).

${ }^{69} \mathrm{Cf}$. Karl Löwith, "The Historical Background of European Nihilism," in Nature, History and Existentialism, edited with a Critical Introduction by Arnold Levison (Evanston: Northwestern University Press, 1966), pp. 3-16. 
because he is contemporary man, because he belongs to an era characterized by nihilism.

Beginning one's philosophical reflection with a confrontation with nihilism holds a promise similar to that offered by Descartes's methodological doubt: it purifies the starting-point by calling everything possible into question. It differs, however, from Cartesian doubt in this essential aspect: it is a lived experience, not simply a methodological postulate. The description of this experience given by Michael Novak is worth quoting at this point. I know of none better, and it will serve well as an introduction to the reflections which follow.

The experience of nothingness defined: that experience in which a man perceives that his former perceptions were structured in a way they did not have to be, in an arbitrary and unnecessary way. There is no obligatory way to perceive things. A kind of giddiness and dizziness arise. One's former goals, aims, purposes now seem suspended in air. The unity of one's life slips from one's grasp, dissolves. Raw, tumultuous experience is overwhelming: how can one shape it, manage it, reduce it to form? Action is problematical because no goal at all seems more valuable, more useful, or more attractive than any other. It is as though at the heart of the human animal there were a love of dissolution, a longing to split into a million measureless particles and fly apart in scattered mist. The experience of nothingness is an experience of the formlessness at the heart of human consciousness. We exist only through form; the experience of our formlessness is terrifying. We know our kinship to nothingness. We dread being reminded of it. 70

To anticipate what will follow, we can say here that this experience of nothingness, of formlessness, of the arbitrary and unnecessary character of our perceptions, is the experience of the play character of p. 3 .

70 Michael Novak, "Introduction," in Helmuth Thielicke, Nihilism, 
the world--the realization that we have created this world, given form and meaning to it, and that this is all that the world is. Insofar as we have been led to expect it to be something more, this experience is a threat to our existence, calling into question that which had previously been unquestionable. As such, play initially stands as a threat to man because of his long-held belief that there is something more to existence. The Meaning of Nihizism

The most important fragments on nihilism, most of which are to be found at the beginning of The Will to Power, were written in the autumn of 1887. In Nietzsche's notebooks they begin with the following description.

1. Nihilism [as] a normal condition.

Nihilism: the goal is lacking: the answer to the question of "why?" is lacking. What does nihilism mean?--that the highest values devaluate themselves. 71

Nietzsche then goes on to distinguish between active nihilism as a sign of increased strength and passive nihilism as a sign of the decline and regression of the spirit's power--a distinction that reminds one of the difference between ascending and decaying types of life discussed above. Active nihilism can arise when the spirit outgrows its old beliefs, frees itself from their authority, and consequently

$71_{\mathrm{NF}}, \operatorname{VIII} / 2,9(35)$, p. 14. "Der Nihilism ein normaZer Zustand. Nihilism: es fehlt das Ziel; es fehlt die Antwort auf das 'Warum?' was bedeutet Nihilism?--dass die obersten Werthe sich entwerthen." All but the first line of this passage is to be found in WM, $\$ 2, \mathrm{p} .10=$ WP, 2, p. 9 . 
turns destructive. As such, it has fundamental similarities to the image of the lion in "The Three Metamorphoses" and to the great breaking-loose discussed above in the section on the free spirit. Again, there are limits on this process. If the spirit stops here, the result is pure destruction. However, for Nietzsche this is not a final state, but rather a pathological, transitional state in which sufficient strength is still lacking "in order to posit for oneself once again a goal, a 'why?', a belief." ${ }^{72}$ If the spirit is to increase its strength, it must go beyond this state of destructive nihilism.

The question of the presuppositions of nihilism is then raised in this fragment, and Nietzsche lists them as these: "that there is no truth; that there is no absolute character to things, no 'thing in itself'."73 Commenting on these presuppositions, he states:

--this is itself nihilism of the most extreme kind. It places the value of things precisely in the lack of any reality corresponding to these values and in their being merely a symptom of strength on the part of the value-positers, a simplification for the sake of life.

$72_{\mathrm{NF}}, \mathrm{VIII} / 2,9(35)$, p. 14. ". . . um produktiv sich nun auch wieder ein Zie1, ein Warum? einen Glauben zu setzen."

${ }^{73}$ Ibid, p. 15. "Daß es keine Wahrheit giebt; daß es keine absolute Beschaffenheit der Dinge, kein 'Ding an sich' giebt."

74Ibid., pp. 15-16. "--dies ist selbst ein Nihilism, und zwar der extremste. Er legt den Werth der Dinge gerade dahinein, daß diesem Werthe keine Realität entspricht und entsprach, sondern nur ein Symptom von Kraft auf Seiten der Werth-Ansetzer, eine Simplification zum Zweck des Lebens." 
There is a dispute over the question of whether Nietzsche's philosophy is a form of nihilism, and passages such as this one would seem to suggest that his philosophy is nihilistic. Arthur Danto has argued that, "Nietzsche's is a philosophy of Nihilism, insisting that there is no order and a fortiori no moral order in the world."75 Arguing against Danto and others, Richard Schacht has maintained that, "careful analysis of his [Nietzsche's] writings shows that he neither considered himself to be a nihilist, nor deserves to be considered one, either metaphysically or axiologically."76 The question is partially one of definition--in regard to the meaning of the term "nihilism"-but goes well beyond that to the more fundamental question of whether Nietzsche's philosophy goes beyond nihilism or not. Schacht maintains that he indeed does go beyond nihilism, quite far beyond it:

Far from holding that there are no truths about reality which may be discovered and stated, because there is no actual nature of things to discover and describe, he [Nietzsche] in fact holds the contrary, and has a good deal to say of a substantive nature in this connection. And far from denying objective validity to all value-judgments as such, he in fact maintains that a certain standard of value has an objective basis in the very nature of things. ${ }^{77}$

Danto, on the other hand, sees Nietzsche's claims for going beyond nihilism to be far more modest: "There is a crucial tension throughout

${ }^{75}$ Arthur C. Danto, Nietzsche as Philosopher (New York: The Macmillan Company, 1965), p. 80; cf. pp. 19-35.

${ }^{76}$ Richard Schacht, "Nietzsche and Nihilism," in Nietzsche. A Collection of Critical Essays, edited by Robert C. Solomon (New York: Doubleday, 1973), pp. 81-82.

$$
{ }^{77} \text { Ibid, p. } 82 \text {. }
$$


Nietzsche, between a free-wheeling critic, always prepared to shift ground in attacking metaphysics, and a metaphysical philosopher seeking to provide a basis for his repudiation of any such enterprise as he is practicing."78 This would suggest that Nietzsche is not actually going beyond nihilism; rather, he is simultaneously going in another direction in addition to his nihilistic one.

Although I would not agree with either of them completely, Danto is far closer to being right in this controversy: there is a crucial tension in Nietzsche's thought. This tension, however, can be resolved in terms of an elaboration of the Nietzschean category of play. The claims that Schacht makes about Nietzsche's adherence to notions of objective truth and value simply ignore too much of what Nietzsche has said in his critique of values and the notion of truth. Since I have treated these matters at other places in the dissertation, it is not necessary to go into these issues in depth here; a brief indication of the argument will suffice. There are more than two possibilities here; it is not an either/or choice between nihilism, on the one hand, and objective values and truth on the other. It is precisely this middle ground which the category of play is able to express. The creative play of the free spirit goes beyond the experience of nihilism while recognizing the validity of its insights. The world is a human creation, but that does not make it meaningless. In creative play one affirms the created character of existence--thus its

${ }^{78}$ Danto, Nietzsche as Phizosopher, p. 80. 
human character--and adds to it by creating new meaning and order. In reaching this stage, nihilism has a liberating effect. It is a "pathological transitional stage,"79 but it is very definitely a stage that most contemporary men must go through. This is one of the factors that Schacht's analysis leaves out: the necessity of nihilism. In order to become free enough to play creatively, contemporary man-insofar as he holds to any absolute interpretation of the world--needs to undergo the experience of nihilism. It is comparable to that of the lion or the great breaking-loose discussed above. Nihilism frees man to play; and as long as man remains unfree, nihilism remains the pathway to creative play. In this sense, Nietzsche's philosophy is not a nihilistic one, but rather a philosophy of the overcoming of nihilism through creative play.

Nihilism accomplishes this task of liberating man by showing that the world is nothing in itself, but only what man has made of it. Passive nihilism becomes resigned in the face of this realization, while active nihilism becomes destructive. In the destructiveness of the active nihilism is hidden the possibility of overcoming nihilism; this possibility emerges into the light when the nihilist realizes that, even in his destruction, he has control over that reality. This is then coupled with a second insight: the nihilist realizes that he

$$
79 \mathrm{WM}, \S 13, \mathrm{p} .16=\mathrm{WP}, \S 13, \text { p. } 14=\mathrm{NF}, \mathrm{VIII} / 2,9(35), \mathrm{p} .15
$$
"Der Nihilismus stel1t einen pathologischen Zwischenzustand dar (-pathologisch ist die ungeheure Verallgemeinerung, der Schluß auf gar keinen Sinn--) . . ." 
is really existing in two worlds simultaneously. His expectations are still rooted in a previous world, a world characterized by faith in the categories of reason. ${ }^{80}$ His experience, on the other hand, is of a world in which there is no necessary order or form, no meaning to things in themselves, in which the categories of reason have no va1idity. The nihilist's problem is this: he still expects the world to be governed by absolute categories. It is from this unjustified expectation that his nihilism arises; and when this expectation is overcome, then he can affirm existence through creative play. Play and the Overcoming of Nihilism

Although Nietzsche never worked out the relationship between play and nihilism in explicit terms, the basic outline of a philosophy of play as the overcoming of nihilism is to be found in his writings. The outline is like a sketch, some lines of which are quite boldly drawn, others only faintly suggested. The preceding remarks have elaborated some aspects of this picture; it now remains to be seen if the picture can be completed.

Play meets the nihilist's experience of meaninglessness and purposelessness on its own terms and yet is able to go beyond those

$$
{ }^{80} \mathrm{Cf} \text {. WM, } \$ 12, \mathrm{p} .13=\mathrm{WP}, \$ 12, \mathrm{p} .13=\mathrm{NF}, \mathrm{VIII} / 2,11(99) \text {, }
$$
p. 291: "Resultat: der Glaube an die Vemunft-Kategorien ist die Ursache des Nihilismus,--wir haben den Werth der Welt an Kategorien gemessen, welche sich auf eine rein fingirte Weit beziehen." Schacht ("Nietzsche and Nihilism," p. 62) implies that it is only the falsity of the Christian moral interpretation of the world that is at stake here, but Nietzsche presents nihilism "als die nothwendige Folge von Christenthum, Moral und Wahrheitsbegriff der Philosophie." NF, VIII/3, $22(24)$, p. 402. 
terms. It grants that nothing in the world has meaning or purpose-but it affirms the world as a created world, as man's creative play. This the nihilist does not do because he still tries to measure the world in terms of the categories of his previous, absolutist worldview. The absence of an absolute order and value in things does not imply the impossibility of any order or value. What is possible is the order and value which emerges from man's creative play.

There is a tendency to suggest that this kind of order, that which arises out of creative play, is no order at al1. Stanley Rosen's criticisms of Nietzsche exemplify this position.

Traditionally, as for example in Plato and Aristotle, power is defined in terms of an actuality--an activity, goal, or end. According to Nietzsche, these are values, or themselves manifestations of the will to power. The world (represented by the earth or body) is altogether the will to power; as a consequence, power cannot be said to manifest itself for an end outside of itself. The temporary and perspectival nature of values reduces them to the status of facts, with respect to the world-process as a whole. The values are devalued; the world is what it is--purposeless play. 81

The first obvious problem with this criticism centers around Rosen's idea of play. Play is not purposeless, but rather characterized by created purposefulness. So, too, the "temporary and perspectival nature of values" does not reduce them to the status of facts. It makes them temporary and perspectival values--nothing more, nothing less. Again, they are created values; to say that these are consequently only facts is to maintain the absolutist position which is the cause of nihilism: either there are absolute values or none at all.

${ }^{81}$ Rosen, Nihilism, p. 97. 
For the nihilist, the categories of "aim," "unity," and "being," in terms of which value had previously been projected into the world, are pulled out of the world, with the result that the world looks valueless. ${ }^{82}$ P1ay reintroduces these categories into existence, but in a finite sense. As already mentioned, there is a purposefulness in play, an aim, but this is a posited aim or purpose--a human creation. Play creates a unified world, and the unity of the world is expressed in its presuppositions and rules; but again, this is a limited unity. There are a multiplicity of such unities, and the creation of the order of rank is concerned with bringing these into relation with each other. So, too, play creates "being," but this "being" is not absolute. It is the degree of apparentness which a given play world can create and express. This involves a creative positing of images, of order, which is the essence of philosophy; again, it does not presuppose any absolute truth. ${ }^{83}$

To consider existence as a game would open up a number of possibilities that the individual might otherwise, after the experience of nihilism, reject. In his notebooks from 1878, Nietzsche had already posed the questions: "Why not consider metaphysics and religion as adults' play?" 84 "Why shouldn't one be allowed to play metaphysically?

\footnotetext{
${ }^{82} \mathrm{WM}, \$ 12$, p. $15=\mathrm{WP}, \$ 15$, p. $13=\mathrm{NF}, \mathrm{VIII} / 2,11(99)$, p. 290. ${ }^{83} \mathrm{WM}, \$ 605$, pp. $414-15=\mathrm{WP}, \$ 605$, p. $327=\mathrm{NF}, \mathrm{VIII} / 2,9(48)$, p. 23.
}

${ }^{84} \mathrm{NF}$ in Menschliches, AlZzumenschliches II. Nachgelassene Fragmente 1878-1879, in Nietzsche Werke, Vierte Abteilung, Dritter Band (Berlin: Walter de Gruyter, 1967), 29(49), p. 378. "Warum lässt man Metaphysik und Religion nicht als Spiel der Emwachsenen gelten?" 
and apply the enormous force of creating to this?" 85 Two years later he would write of himself as, "playing a game with the belief of the whole world."86 A year after that, one of his outlines contained a chapter on "The Game of Life." 87 In the notebooks from the time of The Joyful Wisdom, Nietzsche refers to Zarathustra's new form of superiority: "playing with the holy."88 This appears to open up the possibility of thinking, in its widest sense, as a type of playing. Metaphysics, rejected insofar as it claims to make statements about the real, is transformed into playful thinking which creates its own world and recognizes it to be such. As will be shown later, it is possible to understand some of Nietzsche's central ideas, especially that of the eternal recurrence of the same, as this kind of activity: playful thinking. So, too, the very idea of a "gay science" allows

$85 \mathrm{NF}, \mathrm{IV} / 3,29(45)$, p. 377. "Warum sol1te man nicht metaphysisch spielen dürfen? und ganz enorme Kraft des Schaffens darauf verwenden?"!

${ }^{86} \mathrm{NF}$ in Morgenrothe. Nachgelassene Fragmente. Anfang 1880 bis Frihjahr 1881, in Nietzsche Werke, Fünte Abteilung, Erster Band (Berlin: Walter de Gruyter, 1971), 8(109), p. 735. "Meine geheimen Neigungen, après tout die der Natur, gewisser Affektation von Größe entgegengesetzt, mit der ich mich dekoriren muß, geben mir unendliche Huilfsquellen, um mit dem Glauben aller Welt ein Spiel zu treiben."

${ }^{87}$ Quoted by Alfred Baeumler in the "Vorwort"to UW, I, p. xvi. "Das Spie1 des Lebens."

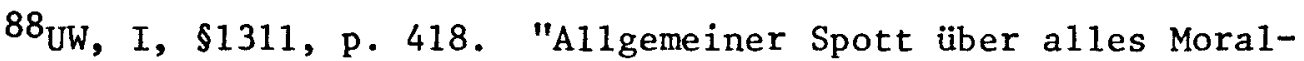
isieren von heute. Vorbereitung zu Zarathustras naiv-ironischer Stellung zu allen heiligen Dinge (neue Form der überlegenheit: das Spiel mit dem Heiligen)." 
itself to be understood as play. 89

That such playing is not limited to trivial matters is already clear from some of the preceding statements, and other texts from Nietzsche confirm this, showing not only that play is serious, but that it can even be a matter of life and death. In Beyond Good and Evil it is maintained that a man's maturity, "consists in having found again the seriousness one had as a child, at play."90 Ten years earlier Nietzsche had considered this same theme in his notebooks when commenting on Eugen Dühring's Der Werth des Lebens. ${ }^{91}$ Noting that Dühring considered the idea of life as play to be insipid, Nietzsche points out that this idea goes back to Plato and argues against Dühring's contention that true pain cannot be contained in play. ${ }^{92}$ Although Nietzsche's own position on the nature of play is not clear from this passage, he does not appear to agree with Dühring that the idea is "insipid."93 In a later entry in the same notebook, however, Nietzsche discusses chance in relation to death, arguing that the greatest attraction is to be found in testing out the element of change in existence, even to the point of playing for life and death. In saying

$$
\begin{aligned}
& { }^{89} \mathrm{UW}, \text { II, } \$ 659 \text {, p. } 211 . \\
& 90_{\mathrm{JGB}}, \text { IV, } \$ 94 ; \text { VI/2, p. } 90=\text { BGE, IV, } \$ 94, \text { p. } 83 \text {. "Reife }
\end{aligned}
$$
eines Mannes: das heisst den Ernst wiedergefunden haben, den man als Kind hatte, beim Spiel."

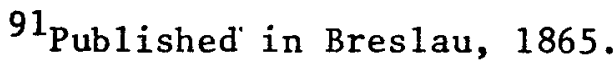

$$
\begin{aligned}
& 92 \mathrm{NF}, \mathrm{IV} / 1,9(1), \mathrm{pp} .224-5 . \\
& \text { 93Ibid., p. } 230 .
\end{aligned}
$$


that "existence is not the playing out of a game where we only have to look on,"94 Nietzsche suggests that it is a game--or play--in which we participate to the fullest, even at the risk of death. This is where the highest energy of life unfolds itself, "where the play of succeeding and failing transforms itself into a test of life and death."95

In this sense, life itself can be considered a game--quite serious, even a matter of life and death, but still fundamentally a game. By so doing, even death is made an act of living, for the individual creates the conditions under which he wills his test with death. This is, in part, a battle with time, for it is the untimeliness of death which gives it such a bitter flavor, and this untimeliness results from chance. By playing for life and death, one is able to set the terms for chance, thereby escaping the plight of being merely the passive victim of chance.

By considering life as a game, by equating living with playing, the nihilist is thus able to go beyond his nihilism, both on the level of thinking (playing metaphysically) and on the level of acting (by playing for 1 ife and death). It is in this insight that nihilism is fully overcome: we are playing, even when it is a question of 1 ife or death. By viewing life in terms of play, the nihilist is able to give full meaning to the experience of nihilism, but nonetheless able

94 Ibid, pp. 239-40. "Der Mensch liebt es unter gewissen Umständen geradezu um Leben und Tod zu spielen. . . Das Dasein ist nicht die Abspielung eines Schauspiels, bei dem wir nur das Zusehn hätten."

95Ibid., p. 242. ". . . wo das Spiel von Gelingen und Mißlingen sich in eine Erporbung vom Leben und Tod wande1t." 
to recognize that there is more to existence: it can be affirmed as play. Indeed, he first devalues existence because he expects it to be something more than this. Nihilism is the expression of man's unwillingness to recognize that existence is play and only play; but as the nihilist discovers that his expectations that existencel be something other than play are unjustified, he moves toward affirming what the experience of nihilism uncovers and from which he draws back: existence is play, life a game, nothing more.

Conclusion

Play has been shown to be the highest form of human activity for Nietzsche in two ways. First, it has been shown that play is the proper activity of the child in "The Three Metamorphoses" and of the free spirit. The doctrine of the order of rank emerged as the expression of the order that such creative play imposes on the world, an order whose foundation is power. This leaves the way open for a consideration of the will to power as play, a topic to be considered in the next chapter. Second, it was shown in a negative sense that play must be the highest form of human activity, since play is the only type of activity which is possible in a meaningful sense after the experience of nihilism--an experience which Nietzsche designated as the characteristic one of the nineteenth and twentieth centuries.

The relationship between the play world and the everyday world has been clarified. There are a multiplicity of worlds, none of which has any claim to absolute being. The task of creative play is to extend one's play world to its farthest limits, and this task is that of the creation of a new order of rank. Such creative play serves 
to reintroduce purposefulness, unity and being back into the particular world under consideration--the play world of the individual player-but these qualities are now seen to be finite and created, not absolute. The world--more precisely, the multiplicity of worlds--is no longer to be understood in terms of opposites (purpose versus purposelessness, unity versus chaos, etc.), but rather in terms of the degree of purposefulness, unity, and being which it possesses as a result of creative human play. Finally, it becomes clear that there is no question of play being outside "the world." It creates its own world. When we say that a given play is outside the world, it is clear that for Nietzsche this would mean that someone else's play world has not been able to extend its boundaries to include our play world.

Certain problems still remain. If play is the highest form of human activity, what categories are we to use to understand what, for the moment, can be called "lower" forms of activity? Is not all activity play? Moreover, to what degree is the individual in control of his play? It has been suggested that the individual is a multiplicity of forces, an interplay of forces. What role does the will play in this regard? Is man really a player or a plaything? Does thinking direct our playing, or is it also the result of an interplay of forces?

These and other related problems lead us into the subject matter of the next two chapters, in which the relationship between morality, the will to power and the category of play will be considered and in which Nietzsche's idea of the self in relation to the 
interplay of forces as affects will be considered in an attempt to clarify and complete this consideration of play as human activity. 
CHAPTER IV

MORALITY AND THE WILL TO POWER

\section{Introduction}

Morality, like everything else in existence, is a game for Nietzsche, but it is distinguished from the creative play of the free spirits in several ways. First, it is not open to newness in existence: it must judge everything in terms of moral values. This leads necessarily to a narrowing of perspectives. Second, it is not creative. Morality is given to us to be followed, rather than created by us. Third, morality represents the values of the herd--the mediocre--and for this reason is in fundamental opposition to the creativity of the free spirits. Fourth, it does not realize that it is an illusion, but rather thinks that it is founded in some ultimate reality. Fifth, morality condemns existence--or at least the greatest part of it--while the free spirits affirm it. Finally, morality is a sign of weakness, while the creative play of the free spirits is characterized by strength.

In this chapter, the critique of morality just outlined in the preceding paragraph will be developed. After this, it will be shown that Nietzsche's doctrine of the will to power represents the overcoming of morality through creative play. On the basis of this analysis, two fundamentally different types of play can then be 
distinguished: creative play organized and controlled by the powerful expressing their will to power, and the play of the weak in which they are dominated by their own game. Morality then emerges as a game of self-delusion that is played by the powerless and which dominates them, and the will to power is to be understood as the creative play of the powerful.

A. Morality as a Game of Self-Deception Morality as Interpretation

Morality is, first of all, an interpretation. There are, Nietzsche argues in Beyond Good and Evil, "no moral phenomena at all, but only a moral interpretation of phenomena." 1 While the moral character of phenomena stems, not from the phenomena themselves, but rather from our interpretation of them, we must realize that this is not an arbitrary interpretation, but rather one which possesses an inner logic. Nietzsche understands morality as, "a system of evaluations which is connected with the conditions of life of a being." 2 How is it connected with them? In his notebooks from 1887, Nietzsche argues that morality may be the only schema of interpretation by means of which man is able to endure himself. ${ }^{3}$ Morality is in this sense

$1_{\mathrm{JGB}}, \mathrm{IV}, \$ 108 ; \mathrm{VI} / 2$, p. $92=\mathrm{BGE}, \mathrm{IV}, \$ 108$, p. 85. "Es giebt gar keine moralischen Phänomene, sondern nur eine moralische Ausdeutung von Phänomenen. . . ."

${ }^{2} \mathrm{WM}, \$ 256$, p. $185=\mathrm{WP}, \$ 256$, p. 148. ". . . ein System von Wertschätzungen, welches mit den Lebensbedingungen eines Wesens sich berührt."

p. 154 .

$$
3_{\mathrm{WM},} \$ 270, \mathrm{p} \cdot 192=\mathrm{WP}, \$ 270, \mathrm{p} \cdot 154=\mathrm{NF}, \mathrm{VIII} / 2,10(121),
$$


is always an interpretation, the purpose of which may be to make 1 ife endurable--especially for the weak. The Instinctual Foundations of Morality

Morality does not, however, always achieve this goal--and when it does, it does so only at a price to the believer in morality. This price is the denial of life, especially the higher forms of life. This is evident in those cases where morality is considered as the will to power of the herd. This particular will to power, according to a fragment written in 1887 , has three "powers" behind it:

1. the instinct of the herd against the strong and independent;

2. the instinct of the suffering and unfortunate against the happy ones;

3. the instinct of the mediocre against the exceptions. ${ }^{4}$ Morality as the will to power of the herd is reducible to particular instincts, which themselves bring about a restriction of power--exemplified in the herd, the suffering and the mediocre--rather than an extension of that feeling--which the strong and independent, the happy ones, and the exceptions represent. Thus Nietzsche criticizes morality because, as a manifestation of the herd instinct, it allows the individual to have value only as a function of the herd..$^{5}$ If "the highest power and splendor actually possible to the type man" 6 were not

${ }^{4} \mathrm{WM}, \$ 274$, p. $195=\mathrm{WP}, \$ 274$, p. $156=\mathrm{NF}, \mathrm{VIII} / 2$, p. 93. "1) der Instinkt der Heerde gegen die Starken Unabhängigen 2) der Instinkt der Leidenden und Schlechtweggekommenen gegen die Glücklichen 3) der Instinkt der Mittelmässigen gegen die Ausnahmen."

$5_{\mathrm{FW}}$, III, $\$ 116, \mathrm{p} .134=\mathrm{JW}$, III, $\$ 116, \mathrm{p} .161$.

6 Zur Genealogie der Moral, "Vorrede," 6 in Nietzsche Werke, Sechste Abteilung, Zweiter Band (Berlin: Walter de Gruyter, 1968), p. $265=$ On the Genealogy of Morals. Ecce Homo, edited by Walter Kaufmann 
achieved, morality would probably be responsible for this. Moral norms are directed against the individual. ${ }^{7}$ Morality has become a sign of weakness, 8 of décadence, 9 of complete psychological corruption. 10 Morality, in short, is the game of the weak--a dangerous one because it threatens the powerful.

Morality is also a "sign language" of our affects, a symptom of physiological occurrences. Moral evaluations are in the end dependent upon our affects.

Moral evaluation is an interpretation, a way of interpreting. The interpretation itself is a symptom of certain physiological conditions, likewise of a particular spiritual level of prevalent judgments: Who interprets?--Our affects.11

This is the basis of an extra-moral interpretation of morality: it

(New York: Random House, 1967), p. 20. ". . . eine an sich mögliche höchste Mächtigkeit und Pracht des Typus Mensch. . ." Hereafter abbreviated as GM and GM, referring to the German and English editions respectively.

$$
\begin{aligned}
& 7_{\mathrm{M}}, \text { II, \$108, p. } 93 . \\
& { }^{8} \mathrm{UW}, \text { II, } \$ 1289, \text { p. } 459 .
\end{aligned}
$$

${ }^{9}$ Ecce Homo, in Nietzsche Werke, Sechste Abteilung, Dritter Band (Berlin: Walter de Gruyter, 1969), p. $309=$ Ecce Homo, in The Portable Nietzsche, translated by Walter Kaufmann (New York: The Viking Press, 1968), p. 272. Hereafter abbreviated as EH and EH, referring to the German and English editions respectively.

10"Disposition und Entwürfe zum Dritten Buch der Umwertung aller Werthe," in Götzendömmerung, Der Antichrist, Ecce Homo, Gedichte, edited by Alfred Baeumler (Stuttgart: Kröner Verlag, 1964), p. 290.

$$
11_{\mathrm{WM},} \$ 254, \text { p. } 184=\mathrm{WP}, \$ 284, \text { p. 148. ". . . das moral ische }
$$
Wertschätzen ist eine Auslegung, eine Art zu interpretieren. Die Auslegung selbst ist ein Symptom bestimmter physiologischer Zustände, ebenso eines bestimmten geistigen Niveaus von herrschenden Urteilen: Wer legt aus?--Unsre Affekte." 
is the manifestation of certain instincts or affects which in themselves are neither moral nor immoral. While these at one time were in the service of self-preservation, they gradually became ingrained and remained even after they had lost their survival value. Or, Nietzsche also suggests, they arose among the slaves in order to gain control over existence through its partial negation; this was the moment when ressentiment became creative. 12 As long as it is the affects which do the interpreting, the moral man is their plaything or tool--morality is not his game, but under the control of the affects. If the moral man were, however, to recognize the role that the affects play in the formation of his moral judgments--and this includes the role which the herd plays--, he would cease to be moral man, for he would have recognized the extra-moral foundation of his morality.

Morality as Negation

A common characteristic of moral interpretations of the world is the negation of some or all of existence. Morality passes judgment on existence: doing this allows it then to assert its control over existence. A basic means employed here in the service of morality is the theory of cause and effect. Interpretation of existence in terms of cause and effect provides man with a way of grasping existence (if only an imaginary, created one), allowing him at least to think that he is controlling the flux of existence. What distinguishes

$12 \mathrm{GM}, \mathrm{I}, \S 10 ; \mathrm{VI} / 2, \mathrm{pp} \cdot 284-88=\mathrm{GM}, \mathrm{I}, \S 10, \mathrm{pp} .36-39$ 
the moral from the extra-moral period in the history of man is the rejection of the traditional framework of causality, and thus a rejection of intentionality. 13 What is important in a given action for those who have gone beyond the moral framework is precisely that which is not intentional. By going beyond the framework of causality and intentionality, the immoralist can discover the fullness of human activity, the perception of which is denied the moralist when he sees human actions within the narrow framework of causality. Morality is necessarily an interpretation of the world which denies much of existence because it is bound to an understanding of the world and human action in terms of cause and effect--a mode of understanding which only touches on the surface, concealing more than it reveals.

The point of contrast to the moral interpretation of the world is that offered by the immoralists. They affirm existence in all its aspects, rather than deny it. ${ }^{14}$ They are the antithesis of those who believe in the Christian or decadence morality. ${ }^{15}$ They are the strongest power--they constitute the world in their own image, 16

13JGB, II, $\$ 32 ; \mathrm{VI} / 2$, pp. $46-47=\mathrm{BGE}, \mathrm{II}, \S 32, \mathrm{pp} .43-45$.

14 Grtzendarmerung, in Nietzsche Werke, Sechste Abteilung: Dritter Band (Berlin: Walter de Gruyter, 1969), p. 81 = Twilight of the Idols, in The Portable Nietasche, pp. 491-92. Hereafter abbreviated as $G D$ and $T W$ respectively.

${ }^{15} \mathrm{EH}$, "Warum ich ein Schicksal bin," 4; VI/3, pp. 365-67= EH, "Why I am a Destiny," 4, pp. 328-30.

p. 232 .

$$
16_{\mathrm{WM}} \$ 116, \text { p. } 84=\mathrm{WP}, \$ 116, \text { p. } 71=\mathrm{NF}, \operatorname{VIII} / 3,15(44) \text {, }
$$


whereas the moralists accept the givenness of morality.

The contrast here is between the moralists and the immoralists, the weak and the powerful, the negators of life and its affirmers. For the moralists the game of existence is something which dominates them. For the immoralists, their power allows them to affirm and creatively transform this game through their creative play--the will to power. Morality, Free Will and Purpose

The conceptual difficulties surrounding the moral interpretation have their foundation in this: schemas of interpretation are mistaken for reality itself. The doctrine of free will provides an example of this. Nietzsche speculates that this probably arose out of the feeling of freedom of the ruling caste. However, it was eventually falsely transferred from the socio-political realm into the metaphysical sphere. 17 The end result of this process was the postulation of something called a "free wil1" which was presumed to have a distinct existence. Such a free will, according to Nietzsche, simply does not exist--it is an invention which does not correspond to anything "in itself," a fiction. Nietzsche's arguments in this regard are not directed primarily against the possibility of becoming free, but rather against the notion of a "free will" which would serve as the foundation of such freedom. Freedom does not come from a faculty, but is created by the will to power in its creative play.

$17_{\mathrm{MA}} \mathrm{II}, \mathrm{II}, \S 9 ;$ IV/3, p. 183 
Not only does such a thing as the "free will" not exist, but to assume its existence results in a distorted view of human activity. Instead of seeing an action as the expression of the entire person-including what we call affects, sensation, evaluations, thoughts and the will--we see the action as the result of the person's will. This is a distortion which results in a man composed of parts--the will, cognitive faculty, sensory apparatus--rather than a totality-in-becoming.

A similar distortion takes place when we interpret actions in terms of purposes. If I consider the significance of an action only in terms of that which it was intended to accomplish, I see only a sma1l part of the fullness of that act. 18 The notion of purpose is a distortion in another sense: I often form a clear notion of my purposes only after $I$ act--or at least when $I$ have a reasonably good idea of how successful my action will be. ${ }^{19}$ Finally, it is often impossible to foresee the consequences of an act. To understand them fully, or as fully as possible, it is necessary to view them as experiments, the results of which can be only dimly anticipated.

The point of the arguments which Nietzsche advances is this: the moral interpretation of the world (1) is a fiction, (2) is a narrow

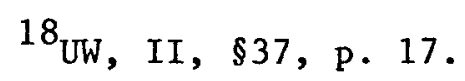

${ }^{19}$ Arthur Danto has described we11 the psychological process involved when we deceive ourselves into thinking that we have such knowledge of our actions; see Danto, Nietzsche as PhiZosopher, pp. 113-14. 
fiction which prevents us from understanding the complexity and the full possibilities of our actions, and (3) is a narrow fiction which mistakes itself to be a statement about reality.

As a narrow and mistaken fictional interpretation of existence, morality judges existence in terms of two categories: good and evil. Not only is there no foundation for these categories in themselves, there is also no basis for saying that existence is to be understood only--or even primarily--in terms of them. The distinction between good and evil creates a univocal world--all things have their value determined in relation to this pair of opposites. But while these categories do not refer to the world itself, they do have a foundation: in the instincts, especially the herd instinct. The foundation in the herd instinct means not only that morality is a game of self-deception, but also that in this game the moralists are really the pawns or playthings of forces beyond their control. Moreover, they cannot recognize this fact and cannot admit that their respective moral systems are only interpretations founded in their respective herd instincts, for that would be tantamount to admitting that the foundation of their morality was an extra-moral one. Morality is the game of the herd and, as such, dominates the members of the herd, making them the playthings in the game rather than allowing them to be true, creative players. Conclusion

Morality, then, is a game of interpretation with certain rules which have their foundation, not in things themselves or a higher moral law, but in our affects and instincts, especially the herd instinct. 
Belief in causality, intentionality and a free will are among the rules of the game. Nietzsche says that the world can be interpreted in this way (since it obviously has been), but it is a mistaken interpretation insofar as it takes itself to be something more than an interpretation, insofar as its narrowness prevents the appearance of the exceptional ones (the creative ones, the immoralists, the free spirits and the overman), and insofar as it is a negation of existence rather than its affirmation. For morality to recognize that it is only an interpretation founded in the instincts of the herd is impossible--unless morality is to become immorality, the moralist the immoralist.

\section{B. The Will to Power}

\section{Willing and Creating}

Nietzsche's critique of morality must be juxtaposed to his positive notion of willing and creating which is found in Thus Spoke Zarathustra and his notebooks. In Zarathustra there is clearly no denial of the will or its importance. For Zarathustra himself, it is the will which frees him, ${ }^{20}$ which is his destiny, to which he sings hymns of praise. ${ }^{21}$ To will is to create; the will is a creator. ${ }^{22}$

$20 \mathrm{Z}$, II, "Auf den Glüclseligen Inseln;"VI/1, pp. 105-08 = Z, II, "On the Blessed Isles," pp. 85-88; Z, II, "Von der Erlösung," VI/1, pp. 173-78 = Z, II, "On Redemption," pp. 137-42.

$21_{Z}$, III, "Von alten und neuen Tafeln;" VI/1, pp. 264-65 = Z, III, "On the 01d and New Tablets," pp. 214-15.

22 Z, II, "Von der Erlösung;" VI/1, pp. 173-78 = Z, II, "On Redemption," pp. 137-42; Z, IV, "Außer Dienst;" VI/1, pp. $317-42=$ Z, IV, "Retired," pp. 258-63. 
The purest will is to be found in the one who wills beyond himself. 23 Zarathustra incarnates this image of the creator, the one who dares to wil1.

The notion of willing that Zarathustra presents here is not to be equated with the concept of a free will which Nietzsche criticizes. Willing for Zarathustra is, first and foremost, a creative activity. As such, it is not the confirmation of a given order of things or the following of a moral law, but a creation--not only of order, but of things themselves, and even of one's self. Second, it is an act of one's entire being. Zarathustra's "wil1" is not in any way an entity separate from him, although his poetic language can be misleading on this point. Third, his will seeks to affirm all of existence--but this is not an indiscriminate affirmation of existence as given, but a creative affirmation in sharp contrast to the destructive negation characteristic of morality.

Arthur Danto remarked that it seemed to be one of Nietzsche's methodological directives "to abolish distinctions wherever found."24 This remark gives us some insight into the basic character of Nietzsche's critique of the will. Traditionally, the will has functioned as a bridge between the mind and the physical world, between thought and action. Nietzsche does not destroy this bridge through a critique

${ }^{23} \mathrm{Z}$, II, "Von der unbefleckten Erkenntnis;" VI/1, pp. 152-56 = Z, II, "On Immaculate Perception," pp. 121-24. ${ }^{24}$ Arthur Danto, Nietzsche as Philosopher, p. 105. 
of the notion of free will in order to sever the two realms, but rather to bring about the collapse of the two into each other. His purpose is to destroy the need for a bridge. The notion of the creative will in Thus Spoke Zarathustra is a formulation of the will to power--a notion which is meant to express the coming together of thought and action in one world as the result of creative play. The Will to Power

The broad outlines of the doctrine of the will to power as creative play have already been presented in a preliminary fashion. Now they must be synthesized into a unified category.

In his notebooks, Nietzsche poses the question: "Is the 'will to power' a kind of 'will' or identical with the concept of 'will'?"25 After asking whether the will to power is the same as desiring, as commanding, as Schopenhauer's will as the "in itself of things," Nietzsche puts forth his position.

My proposition is: that the will of previous psychology is an unjustified generalization, that this will does not exist at aIZ, that instead of grasping the idea of the development of one definite will into many forms, one has eliminated the character of the will by subtracting from its content, its 'whither'?26

$$
25 \text { WM, \$692, p. } 468=W P, \$ 692, \text { p. } 369=\mathrm{NF}, \mathrm{VIII} / 3,14(21), \mathrm{p} .
$$
93. ". . . ist 'Wille zur Macht' eine Art 'Wille' oder identisch mit dem Begriff 'Wille'?"

${ }^{26}$ Ibid. ": mein Satz ist: daß Wille der bisherigen Psychologie, eine ungerechtfertigte Verallgemeinerung ist, daß es diesen willen gar nicht giebt, daß statt die Ausgestaltung Eines bestimmten Willens in viele Formen zu fassen, man den Charakter des Willens weggestrichen hat, indem man den Inhalt, das Wohin? heraus subtrahirt hat." (The italics are given in the Colli and Montinati edition and followed in the translation above, which differs in regard to the italics from Kaufmann's translation.) 
Criticizing Schopenhauer's notion of will as being "a mere empty word," Nietzsche continues by arguing that even the "will to live" is but a special case of the will to power. From this one may conclude that the "whither?" which must be included in the notion of a definite will is "power."27 The will to power is then one definite will, definable in terms of the "whither" of power, which develops into many forms. In the same passage, Nietzsche argues further that this will to power is the primitive affect form, ${ }^{28}$ and that all other affects are only developments of it, giving some idea of some of the "forms" this might take.

The "whither" of the will to power is power itself: especially the increase of power:

- . not merely conservation of energy, but maximal economy of use, so the only reality is the wizl to grow stronger of every center of force--not self-preservation, but the will to appropriate, dominate, increase, grow stronger. 29

The will to power then divides itself into many specific centers of

${ }^{27}$ This formulation should not be taken to imply the existence of power outside of the will. Heidegger's formulation of the relationship between will and power is quite accurate: "Das Wesen der Macht ist Wille zur Macht, und das Wesen des Willens ist Wille zur Macht." Martin Heidegger, Nietzsche (Pfullingen: Neske, 1961), Vo1. II, p. 265.

$$
28 \mathrm{WM}, \$ 688, \text { p. } 465=\mathrm{WP}, \$ 688, \text { p. } 366=\mathrm{NF}, \mathrm{VIII} / 3,14(121), \mathrm{p} \text {. }
$$
92. "Daß der Wille zur Macht die primitive Affekt-Form ist, daß alle anderen Affekte nur eine Ausgestaltungen sind . . ."

$$
{ }^{29} \mathrm{WM}, \$ 689, \mathrm{p} .466=\mathrm{WP}, \$ 689, \mathrm{p}: 367=\mathrm{NF}, \mathrm{VIII} / 3,14(81), \mathrm{p} \text {. }
$$

53. ". . nicht bloß Contanz der Energie: sondern Maximal-ökonomie des Verbrauchs: so daß das Stärker-werden-wollen von jedem Kraftcentrum aus die einzige Realität ist,--nicht Selbstbewahrung, sondern Aneignung, Herr-werden-, Mehr-werden-, Stärker-werden-wollen." 
force, and on this basis plurality is introduced into a world which is "the will to power and nothing more." 30 The interaction of these specific centers of force, each of which seeks to expand and increase its power, is the basic interplay of the universe. This process takes place on every leve1 from the cosmic to the human. Here we are concerned with the specifically human instances of this will to power, for it is here that it finds its most complex and most powerful manifestation. Here the play of forces in the universe is transformed into the creative play of the will to power reaching its highest expression.

The Opposite of the Wizl to Power

How is difference introduced into the Nietzschean universe? Is there another operative principle, in addition to--or within--the will to power, a counter principle, to account for the possibility of opposition?

Four possibilities present themselves. First, Nietzsche himself writes of the principle of Zaisser-alzer as a counter principle to the will to power, 31 and he implies a connection between that and the instincts of decadence. Yet is it not possible to see these very instincts as a weaker manifestation of the will to power itself? The The instinct of decadence is indeed referred to as an instance of the

30 WM, $\$ 1067$, p. $697=W P, \$ 1067$, p. 550. ". . dieser Wille zur Macht--und nichts außerdem!"

$$
{ }^{31} \mathrm{WM}, \$ 122, \mathrm{p} .89=\mathrm{WP}, \$ 122, \mathrm{p} .75 .
$$


will to power. ${ }^{32}$ Our drives themselves are reducible to the will to power. ${ }^{33}$ If so, then all conflicts appear to be cases of a conflict of the will to power with itself. But what separates it into these various centers of force which conflict with each other? The principle of Zaisser aller is in the end reducible to the will to power, but it can function as a counter-principle in this way: it consists of weakness, "letting go," the decline of power. Morality, decadence, laisser alzer as signs of weakness are counter-instances of a strong will to power. They are still the will to power, but a declining one. They provide an opposition to the increasing will to power: strength versus weakness, increase in power versus decrease in it. This corresponds to Heidegger's position that, since the essence of power is to increase itself, to over-power itself, the opposite of the will to power is the powerlessness to power. ${ }^{34}$

A second possibility is that the will to power provides its own internal opposition by splitting into various parts. Where the attempt at appropriation and assimilation fails and a unity is not achieved, a duality arises as the result of the will to power, with the consequence that, "in order not to let go what has been conquered, the will to power divides itself into two wills (in some cases without p. 112 .

$$
{ }^{32} \mathrm{WM}, \S 461, \text { p. } 323=\mathrm{WP}, \S 461, \text { p. } 254=\mathrm{NF}, \mathrm{VIII} / 3,14(135),
$$

${ }^{33} \mathrm{UW}$, II, $\$ 838$, p. 287.

${ }^{34} \mathrm{Cf}$. Heidegger, Nietzsche, II, p. 266. 
completely surrendering the connection between its two parts)." 35 What I think Nietzsche means here is this: one instance of the will to power, when threatened with the possibility of disintegrating completely because it is trying to control too much, makes a strategic retreat and splits into two instances. If we look at this in terms of the idea of creative play, it would mean that when the tension of keeping one play world together becomes so great as to threaten the destruction of that entire world, two smaller, more manageable worlds are created. But this explanation does not account for the original opposition which gives rise to the tension.

A third way of approaching the problem would be to argue that the principle of opposition is nothingness. The close relation between the will to power and nihilism suggests this avenue of approach as consonant with Nietzsche's thinking. The will to power and the transvaluation of all values represent a movement that, "in some future will take the place of this perfect nihilism--but presupposes it, logically and psychologically, and certainly can come only after and out of it. "36 Furthermore, if nihilism is taken as formlessness, then the will to

$$
35_{\mathrm{WM}}, \$ 656, \mathrm{p} .438=\mathrm{WP}, \$ 656, \mathrm{p} .346=\mathrm{NF}, \mathrm{VIII} / 2,9(151), \mathrm{p} .
$$
88. ". . um nicht fahren zu lassen, was erobert ist, tritt der Wille zur Macht in zwei Willen auseinander (unter Umständen ohne seine Verbindung unter einander vö1lig aufzugeben) . . ."

$$
{ }^{36} \mathrm{WM} \text {, "Vorrede," 4, p. } 4 \text { = WP, "Preface," 4, pp. 3-4. ". . . }
$$
eine Bewegung, welche in irgend einer Zukunft jenen vollkommenen Nihilismus ablösen wird; welche ihn aber voraussetzt, logisch und psychologisch, welche schlechterdings nur auf ihn und aus ihn kommen kann." 
power as forming, shaping, and reshaping ${ }^{37}$ finds its counter-principle in formlessness. This interpretation allows room for the first alternative considered above, for the instincts of decadence stand in an inverse relationship to the will to power: "wherever the will to power declines in any form, there in invariably also a physiological decline, décadence." 38 Nothingness, formlessness, décadence, Zaisser aller all indicate a decreasing power. Nothingness as formlessness presents the best formulation of such a principle. Insofar as Nietzsche considers nihilism as a historical movement rather than as an ever-present possibility, nihilism must be taken as a particular instance of a decrease in power. This interpretation does no injustice to the nihilist's experience, for it is characterized precisely by the lack of power to hold his world together.

There is a fourth way of approaching this problem, again beginning with the idea that the will to power can only express itself in opposition. The highest will to power, Nietzsche argues in a fragment from 1883-85, is "to impose upon becoming the character of being." 39 It is in the notion of the eternal recurrence, the idea that "everything recurs," that one encounters "the closest approximation of a p. 88.

$$
37_{\mathrm{WM}}, \$ 656, \text { p. } 438=\text { WP. } \$ 656, \text { D. } 346=\mathrm{NF} . \mathrm{VIII} / 2.9(151) .
$$

${ }^{38}$ A. 17; VI/3. D. $181=$ A. 17. D. 583. "Wo in irgend welcher Form der Wille zur Macht niedergeht. giebt es jedes Mal auch einen phvsiologischen Rückgang. eine décadence."

${ }^{39} \mathrm{WM}, \$ 617$, p. $418=\mathrm{WP}, \$ 617$, p. 330 . "Dem Werden den Charakter des Seins aufzuprägen--das ist der höchste Wille zur Macht." 
world of becoming to the world of being." 40 Here, in the imposition of the character of being upon becoming, the greatest opposition is encountered. But is this not the same dichotomy as that between form and formlessness, the will to power and nothingness? The highest form of the will to power is the willing of the eternal recurrence, the imposition of the character of being upon becoming, for it is here that one encounters the highest degree of resistance, the greatest opposition.

The above remarks provide us with the foundation for the formulation of a counter-principle for the will to power, a principle which manifests itself in powerlessness, becoming, formlessness, nothingness and nihilism. Moreover, it reveals the fundamental meaning of the will to power as the imposition of order and form on chaos and formlessness, and it is here that the meaning of the will to power as creative play becomes apparent. Moreover, it allows us to understand the apparently pointless repetition in the end of the last fragment of The Wizl to Power, where Nietzsche describes his vision of the universe as a monstrous play of forces.

This world is the will to power-and nothing besides! And you yourselves are also this will to power-and nothing besides! 41

${ }^{40}$ Ibid. "Daß alles wiederkehrt, ist die extremste Annäheming einer Welt des Werdens an die des Seins:-Gipfel der Betrachtung."

$41_{\mathrm{WM}}, \$ 1067, \mathrm{p} .697=\mathrm{WP}, \$ 1067, \mathrm{p} .550$. "Diese Welt ist der Wille zur Macht--und nichts außerdem! Und auch ihr selber seid dieser Wille zur Macht--und nichts außerdem!" 
Everything is the will to power, but on its lowest levels it is least organized--formless, chaotic, dispersed. On its highest levels it is most ordered, giving form, imposing the character of being on becoming. In both senses, the will to power is play. On its lowest levels, it is the chaotic play of forces; on its highest levels, the creative play of the powerful. The world is the will to power, and we are the will to power; but insofar as our will to power does not give order and meaning to the world, it remains a random play of forces. As one moves up the order of rank of power, one sees the way in which play transforms itself: at its lowest reaches, it is a random, chaotic activity; at its highest points, a creative activity which builds entire worlds. The Nietzschean category which holds this view of play together throughout its many forms is the will to power.

Thus the decline or absence of power represents the counterprinciple against which all creative play struggles. In order to create order, form, meaning and beauty in the world, the specific wills to power must continually seek to extend the boundaries of their created worlds. The specific ways in which this is done will be considered in the next chapter, where Nietzsche's notions of the overman and self-overcoming are considered. Conclusion

It is now possible to distinguish between two fundamentally different types of play in Nietzsche's philosophy: the creative play of the will to power in its higher manifestations and the declining play of morality and other forms of existence which are characterized 
by the decrease in power. Whereas the play of the creative will to power affirms existence in its creative activity, the moralist's game denies it by judging it only in terms of moral value. Whereas the creative play of the will to power affirms the totality of man's existence, the game that the moralists play divides man into parts-will, cognition, sensation--and affirms one or two of these at the expense of the remainder. The creative play of the will to power seeks to expand itself, moral games seek to fortify themselves against intrusion. Whereas the person who is his will to power most fully is most in control of his play, the moralists--because of their powerlessness, because of their herd instinct, and because they do not recognize the forces at work on them--are but pawns in a game outside of their control. 
CHAPTER V

ON THE SELF, SELF-OVERCOMING AND THE OVERMAN

\section{Introduction}

The self is not a static entity for Nietzsche, but rather an interplay of affects. This interplay can be such that thinking and willing are dominated by the play of affects, in which case willing and thinking are made into the playthings of the affects. There is, however, a second sense in which the self is play--the self as the will to power whose creative play organizes and directs the forces under its command. The self as play in this sense is the overcoming of the traditional concept of the self. The symbol of the highest degree of such self-overcoming for Nietzsche is the overman.

In this chapter this two-fold notion of the self as play will be developed in relation to the ego, willing, thinking, evaluations, sensations and the affects in order to show that the fundamental meaning of self-overcoming on each of these levels resides in creative play. This category of creative play is the key to Nietzsche's doctrine of the overman.

In dealing with the problem of the "ego," Nietzsche directs his remarks toward three main themes: (1) the way in which the ego brings about an overcoming of the herd instinct, (2) the linguistic basis of the concept of the ego, and (3) the relationship between 
the concept of the ego and the belief in causality, being, and things. He also discusses the possibility of overcoming the "ego-feeling," and this notion of overcoming is directly related to the will to power as creative play. It will be shown here that his criticisms are directed against those conceptions of the ego which would reduce the ego to an independent entity, and that he argues in favor of a notion of the ego as will to power. The concept of the ego as an independent entity results in its becoming a plaything of the affects, while the ego as the will to power emerges as the creative player in existence. The Ego as the Overcoming of the Herd

Zarathustra's argument in favor of the ego is based in part on his conception of the ego as the negation of the herd instinct. The clever and self-seeking ego marks the decline of the herd. ${ }^{1}$ Thus Zarathustra exhorts us to pronounce the ego wholesome and whole, ${ }^{2}$ a position which would seem to entail the rehabilitation of man's drives. ${ }^{3}$ In his speech, "On the Afterworldly," Zarathustra puts the matter even more forcefully.

Indeed, this ego and the ego's contradiction and confusion still speak most honestly of its being--this creating, willing, valuing ego, which is the measure and value of all things. And this most honest being, the ego, speaks of the body and still wants the body, even when it poetizes and raves and flutters with broken

1Z, I, "Von rausend und Einem Ziele;" VI/1, p. $72=\mathrm{Z}, \mathrm{I}$, "On the Thousand and One Goals," p. 60.

2Z, III, "Von den drei Bösen;" VI/1, p. $236=Z$, III, "On the Three Evils," p. 191.

$3_{\mathrm{UW}}$, II, $\$ \$ 376-77$, pp. 495-97. 
wings. It learns to speak ever more honestly, this ego: and the more it learns, the more words and honors it finds for body and earth. 4

It is the ego which creates, wills and values, which is the measure and value of things. Clearly, this is not an ego which exists only on the conceptual level, but rather one that wants to make itself incarnate in the world through the body. It is this experience of the ego which leads to a new sense of pride, the will to create "a meaning for the earth . . to will this way which man has walked blindly, and to affirm it and no longer to sneak away from it like the sick and decaying. ${ }^{5}$ The appearance of the ego--as presented in this passage--indicates that man is beginning to take hold of his existence. Instead of walking blindly, he wills and thereby affirms his path. The appearance of the ego indicates the first stirrings of the will to power.

The Linguistic Basis of the Concept of the Ego

Nietzsche's arguments against the concept of the ego begin

${ }^{4} \mathrm{Z}, \mathrm{I}$, "Von den Hinterweltern;" VI/1, p. $32=\mathrm{Z}, \mathrm{I}$, "On the Afterworldly," p. 32. "Ja, diess Ich und des Ich's Widerspruch und Wirrsal redet noch am redlichsten von seinem Sein, dieses schaffende, wollende, werthende Ich, welches das Maass und der Werth der Dinge ist.

"Und diess redlichste Sein, das Ich--das redet vom Leibe, und es will noch den Leib, selbst wenn es dichtet und schwärmt und mit zerbrochnen Flügeln flattert.

"Immer redlicher lernt es reden, das Ich: und je mehr es lernt, um so mehr findet es Worte und Ehren für Leib und Erde."

${ }^{5}$ Ibid., p. $33=i b i d .$, p. 32. ". . . der Erde Sinn ... diesen Weg wollen, den blindlings der Mensch gegangen, und gut ihn heissen und nicht mehr von ihm bei Seite schleichen, gleich den Kranken und Absterbenden!" 
with his critique in The Down, although there is clearly an implied critique of the self already to be found in his notion of the Dionysian overcoming of the self. In the section on, "The So-Called 'Ego'," Nietzsche argues that our concept of the ego is 1 imited by our language and misshapen through its prejudices. ${ }^{6}$ To presume that we are limited in our being to that of which we are conscious and that for which we have words is to open the door to misunderstanding ourselves. In a similar way, the reflexive pronoun represents a self quite different from the subject. ${ }^{7}$ The false opinion which arises out of this linguistic confusion is, however, significant in that it shapes our character and destiny. In the Preface to Beyond Good and Evil, Nietzsche points out the way in which the ego superstition is but an up-dated version of the "soul superstition." 8

The belief in the ego is, then, an unjustified generalization insofar as the content of that belief is not coextensive with the ego itself. This unjustified generalization is perhaps inescapable, given the nature of 1anguage. ${ }^{9}$ The ego is a complex reality, not a a thing--but language destroys this complexity, substituting a single word for it. Nietzsche's arguments here are not directed against that complex reality to which the concept of the ego refers, but against

$$
\begin{aligned}
& { }^{6} \mathrm{M}, \mathrm{II}, \S 115 ; \mathrm{V} / 1, \mathrm{p} .105 . \\
& { }^{7} \mathrm{UW}, \mathrm{II}, \S \S 163-64, \mathrm{p} .62 . \\
& { }^{8} \mathrm{JGB}, " \text { Vorrede;" VI/2, p. } 3=\mathrm{BGE}, " \text { Preface," p. } 2 . \\
& { }^{9} \mathrm{WM}, \S 552, \mathrm{p} .358=\mathrm{WP}, \$ 522, \mathrm{p} .283 ; \mathrm{UW}, \mathrm{II}, \S 33, \mathrm{p} .16 .
\end{aligned}
$$


the over-simplification involved in our concept of the ego. The Concept of the Ego and the Belief in Causality, Being and Things Nietzsche adds to these criticisms in his discussion of "The Four Great Errors," and in his notebooks. In The Twilight of the Idols the belief in the ego is seen as a consequence of the belief in the will as a cause (the ego as "subject," the cause of thoughts). Arguing against mental causes, for which the will is the paradigm, Nietzsche maintains that the ego has become, "a fable, a fiction, a play on words: it has altogether ceased to think, feel, or will!"10 It is only a piece in a conceptual game philosophers play--a fiction which they mistake for a reality. As such, it is incapable of being the cause of anything.

In addition to this, the belief in the ego is the foundation of our belief in the concepts of "being" and "thing." Man ". . even took the concept of being from the concept of the ego; he posited 'things' as 'being' in his image, in accordance with his concept of the ego as a cause."11 Thus it comes as no surprise when man finds being and thingness in the world, for he himself put them there. Nietzsche implies that practicallv the entire framework of Western thought has developed out of the belief in the ego.

${ }^{10} \mathrm{GD}$, "Die vier großen Irrtümer," 3; VI/3, p. $85=\mathrm{TI}$, "The Four Great Errors," 3, p. 495. "Das ist zur Fabel geworden, zur Fiktion, zum Wortspiel: das hat ganz und gar aufgehört, zu denken, zu fühlen und zu wollen!"

11 Ibid. ". . . er nahm erst den Begriff Sein aus dem Begriff Ich heraus, er hat die 'Dinge' als seiend gesetzt nach seinem Bilde, nach seinem Begriff des Ichs als Ursache." 
The origins of this belief are two-fold. First, as already mentioned, the concept of the ego can be traced back to the superstition of the soul. A second source of this belief is the necessity of dealing with the world, although out very survival is not contingent on this necessity. 12 We need unities in order to be able to reckon, and the concept of the ego is the paradigm for the concept of unity. 13 Insofar as the concept of the ego is the foundation of "being," and insofar as knowledge is only possible on the basis of a belief in being, then the concept of the ego is the condition of the possibility of knowledge. ${ }^{14}$ But within this context, being is something which is imposed upon the world of becoming, a falsification, "a perspective illusion--an apparent unity that encloses everything like a horizon."15 This statement can be developed in two different ways. If the ego is the paradigm of all being, and if the ego is in fact not being but becoming. ${ }^{16}$ then the world of being is an illusion. The task for the future would then be a rethinking of the nature of existence in such a way that the traditional categories of reason, grounded in a concept of being, are replaced by categories of becoming.

\footnotetext{
$12 \mathrm{UW}$, II, $\$ 115$, p. 53 .$$
{ }^{13} \text { WM, } 6635, \text { p. } 428=W P, \$ 635, \text { p. } 338=N F, \operatorname{VIII} / 3,14(79) \text {, }
$$
p. 50 .

${ }^{14} \mathrm{WM}, \S 518$, p. $355=\mathrm{WP}, \S 518$, p. 281 .

${ }^{15}$ Ibid. ". . eine perspektivische IZZusion... die scheinbare Einheit, in der wie in einer Horizontlinie alles sich zusammenschließt."

$$
{ }^{16} \mathrm{WM}, \S 519, \text { p. } 355=\mathrm{WP}, \S 519, \mathrm{p} .281 .
$$
}


But there is another way of developing the implications of this statement. If the highest form of the will to power is the imposition of the characteristics of being on the world of becoming, ${ }^{17}$ then the concept of the ego would appear as the highest expression of the will to power. In one sense this does not appear to be the direction that Nietzsche wants to go in at all, since it would appear to give a justification for the metaphysical concept of the self which he wants to reject. However, this line of thinking is in harmony with his own concept of the self as presented in Thus Spoke Zarathustra: a created self which gives stability, order, and being to the world of becoming. However, this apparent contradiction can be resolved. The creation of the self through the will to power does not involve a metaphysical notion of a self existing "in itself." It is clearly a created self that is at issue here. The fullest expression of the will to power involves the creation of the most powerful self; it does not imply that that self has any independent existence as a metaphysical entity apart from the will to power. This self, as created by the will to power, is not a thing but an on-going process. It gives--creates-order, stability, and being to the world of becoming through its creative play and thereby creates itself.

The main thrust of Nietzsche's criticisms of the ego directs itself against the concept of the ego as an independent entity existing in the world of things, of being. The ego is a simplification

$$
{ }^{17} \mathrm{WM}, \$ 617, \mathrm{p} .418=\mathrm{WP}, \$ 617, \mathrm{p} .330 .
$$


necessarily leading to a division of the self. It can never encompass or be identical with "the central government of our nature" because it is only a conceptual synthesis, ${ }^{18}$ nor can it be one with the totality of being because it introduces an ego/non-ego distinction. ${ }^{19}$ Thus the concept of an independent ego leaves us with a bifurcated world. Furthermore, once this dichotomy between ego and non-ego is established, there is a tendency on the part of the ego to feel overpowered by the immensity of the non-ego. ${ }^{20}$ This results in the denial of the ego, the triumph of the herd instinct, and the prohibition of the strongest, most natural and only real drives. Finally, perceiving things within the ego/non-ego framework clouds our vision of the world by forcing our perception into one particular framework, reifying what would otherwise by a multiplicity of processes and relationships into a limited set of "things." 21

Overcoming the "Ego-Feeling"

Thus the possible benefits connected with overcoming the "egofeeling" (das Ichgefuhl) would include an expanded perception of the world.

$18_{\mathrm{WM}}, \$ 371$, p. $251=\mathrm{WP}, \$ 371$, p. 200. "Das 'Ich'--welches mit der einheitlichen Verwaltung unsres Wesens nicht eins ist!--ist $j a$ nur eine begriffliche Synthesis." p. 152 .

$$
{ }^{19} \mathrm{WM}, \$ 786, \mathrm{p} .525=\mathrm{WP}, \$ 786, \mathrm{pp} .413-14=\mathrm{NF}, \mathrm{VIII} / 2,10(57),
$$

${ }^{20}$ Tbid.

${ }^{21} \mathrm{UW}, \mathrm{II}, \$ 447$, p. 180 . 
If we eliminate these additions, no things remain but only dynamic quanta, in a relation of tension to all other dynamic quanta: their essence lies in their relation to all other quanta, in their "effect" upon the same. The will to power is not a being, but a pathos--the most elemental fact from which a becoming and effecting first emerge. 22

The world for Nietzsche then becomes a collection of dynamic quanta of the will to power, each one of which is related to all others, but which are not to be understood under the category of causality.

Yet one would want to ask at this point: what is left of the self? Have we in the process of achieving liberation simultaneously destroyed that which was to be liberated? Here I think that Nietzsche would argue that the self has not been destroyed, but rather our traditional interpretation of the self has been shown to be a falsification. The self is no longer an isolated entity, but rather is the creative play of the will to power. The degree to which it is will to power determines its strength, determines the degree to which it can create itself through its creative play.

The framework for the following interpretation is to be found in a fragment in Nietzsche's notebooks in which he sketches the relationship among a number of his key categories.

Our intellect, our will, even our sensations are dependent upon our value judgments: these correspond to our drives and the

$$
{ }^{22} \text { Wh, } \$ 635, \text { p. } 429=W P, \$ 635, \text { p. } 339=N F, \operatorname{VIII} / 3,14(79), p .
$$

51. "Eliminiren wir diese Zuthaten: so bleiben keine Dinge übrig, sondern dynamische Quanta, in einem Spannungsverhältniß zu allen anderen dynamischen Quanten: deren Wesen in ihrem Verhältniß zu allen anderen Quanten besteht, in ihrem 'Wirken' auf dieselben--der Wille zur Macht nicht ein Sein, nicht ein Werden, sondern ein Pathos ist die elementarste Thatsache, aus der sich erst ein Werden, ein Wirken ergiebt . . ." 

conditions of their existence. Our drives are reducible to the
will to power.

I shall attempt to show the ways in which our intellect, will and sensations are dependent upon our evaluations, and why these must correspond to our drives. Finally, the relationship among the various drives will be shown to be that of either a free play of forces, in which case the self becomes the plaything of those forces, or a creative play organized by the individual's will to power, in which case the self becomes the player.

There are two senses in which thinking is play for Nietzsche. First, it reflts from the interplay of affect. As such, thinking is really the plaything of the affects. Second, when the person realizes the true nature of thinking and its relation to the affects, it becomes possible for him to affirm this relationship and to organize it. This is the second way in which thinking can be play; thinking as the will to power organizes the play of affects into a creative play. In this case, thinking is an expression of the creative will to power of the thinker.

The Dependence of Intellect, Will and Sensation on Evaluations 24

$23 \mathrm{UW}, \mathrm{II}, \S 838$, p. 287. "Unser Intellekt, unser Wille, ebenso andere Empfindungen sind abhängig von unseren Wertschätzungen: diese entsprechen unseren Trieben und deren Existenzbedingungen. Unsre Trieben sind reduzierbar auf den Willen zur Macht."

${ }^{24}$ Throughout this section there are references to thinking, willing, sensation, etc. which give the impression that these exist in themselves apart from each other and the multiplicity of forces whose activity constitutes the self. This misleading impression is unavoidable, given the misleading character of language. 
The Intellect and Thinking. The intellect appears as the place where the various affects compete with one another for dominance. There is no drive for knowledge, rather the intellect is "in the service of various drives."25 In the notebooks from the period of The Down, Nietzsche pictures the intellect in the following terms.

The intellect is the tool of our drives and nothing more; it will never be free. It sharpens itself in the struggle of the various drives, and refines the activity of each individual drive thereby. The will to power, to the infallibility of our person is in our greatest justice and honesty: skepticism arises only in relation to all authority. We do not want to be duped, not even by our drives! But then what does not want that? Certainly a drive! ${ }^{26}$

Nietzsche attempts to substantiate the thesis that the intellect is the tool of our drives through consideration of specific ideals and moral judgments, in each case reducing the ideal to the emotions that gave rise to it and arguing that its expression in language is but another way in which the drive seeks dominance. ${ }^{27}$

Thinking is then a sign language, pointing to the competing drives, each of which seeks to gain dominance over the others. ${ }^{28}$ In

${ }^{25} \mathrm{UW}, \mathrm{I}, \$ 639$, p. 243. "Kein 'Erkenntnistrieb': der Intellekt im Dienst der verschiedenen Triebe."

${ }^{26} \mathrm{UW}, \mathrm{II}, \$ 348$, p. 132. "Der Intellekt ist das Werkzeug unserer Triebe und nichts mehr, er wird nie frei. Er schärft sich im Kampf der verschiedenen Triebe, und verfeinert die Tätigkeit jedes einzelnen Triebes dadurch. In unserer größten Gerechtigkeit und Redlichkeit ist der wille nach Macht, nach Unfehlbarkeft unserer Person: Skepsis ist nur in Hinsicht auf alle Autorität, wir wollen nicht düpiert sein, auch nicht von unseren Trieben! Aber was eigentlich will denn da nicht? Ein Trieb gewiß!"

$$
\begin{aligned}
& { }^{27} \text { UW, II, } \$ 352, \text { p. } 134 \text {. } \\
& { }^{28} \text { UW, II, } \$ 253, \text { p. } 97 \text {. "Das Denken ist. . . nur eine Zeichen- }
\end{aligned}
$$
sprache für den Machtausgleich von Affekten." 
his explanations, Nietzsche uses several images. When speaking of the intellect as a "tool" of drives or affects, 29 he implies a purposeful activity on the part of the affects since the notion of a tool implies a purpose. The intellect is a tool insofar as the various drives and affects seek to gain more power by means of it. The term "tool" implies purpose only in this sense. Insofar as these affects are related to each other in an interplay of affects, thinking could also be called their "plaything." Insofar as Nietzsche employs the image of a struggle among the affects, the term "tool" is more appropiate. The notion of a struggle is often the dominant one, and in this image it is the struggle itself which seeks to maintain itself, ${ }^{30}$ not the being in which the struggle takes place. An alternate view is the suggestion that it is the affects which bring about the struggle. In either view it is the activity, the interaction among the various affects, which constitutes the primary reality. The intellect and thinking are, in this view, simply the by-products of this process; they in no way cause it.

Nietzsche does not seem to differentiate clearly between play and struggle. He suggests that thoughts are, "signs of a play and struggle of the affects: they always hang together with their hidden roots." ${ }^{31}$ This leads to the rejection of a unified subject and the

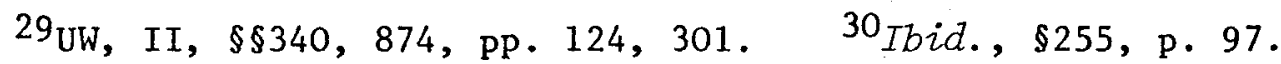

${ }^{31}$ UW, II, $\$ 248$, p. 95. "Die Gedanken sind Zeichen von einem Spiel und Kampf der Affekte: sie hängen immer mit ihren verborgenen Wurzeln zusammen." 
substitution of Nietzsche's hypothesis about the subject as a multiplicity of forces, "whose interplay and struggle constitutes the foundation of our thinking and even our consciousness." 32 Thinking then appears as something which happens in the subject, an interplay of sensations.

Our thinking is really nothing but a very refined interwoven play of seeing, hearing, feeling, the logical forms are physiological laws of sensory perception. Our senses are developed centers of sensation with strong resonances and mirrors. 33

Viewed in this manner, thinking appears to be equivalent to fantasy, as is suggested in a fragment from this same period. Thinking, our fundamental intellectual life, is the "playful pondering of material . . This spontaneous play of fantasizing force is our fundamental intellectual life." 34 We seldom become conscious of this process, but rather engage in the grossest of oversimplifications. Although Nietzsche suggests in this fragment that precise hearing and seeing, in contrast to the fantasy which we mistake for true perception, is possible, it is seldom achieved.

$32 \mathrm{WM}, \$ 490$, p. $341=\mathrm{WP}, \$ 490$, p. 270. ". . . deren Zusammenspie1 und Kampf unserem Denken und überhaupt unserem Bewußtsein zugrunde liegt..."

${ }^{33} \mathrm{NF}, \mathrm{V} / 1,6(433)$, p. 639. "Unser Denken ist wirklich nichts als ein sehr verfeinertes zusammengeflochtenes Spiel des Sehen Hörens Fühlens, die logischen Formen sind physiologische Gesetze der Sinneswahrnehmungen. Unsere Sinne sind entwickelte Empfindungscentra mit starken Resonanzen und Spiegeln."

${ }^{34}$ Ibid., 10 (D79), p. 760. ". . spielende Verarbeiten des Materials . . Dieses spontane Spiel von phantasirender Kraft ist unser geistiges Grundleben." 
The necessity for the oversimplification characteristic of most thinking is to be found in our need to perceive things as wholes. For example, we think we see the movement of a bird as movement, when we actually interpret the data of our perception and infer the movement from that. ${ }^{35}$ We put in more than is there at times. In another fragment Nietzsche uses the same premise, that perception imposes a unity not otherwise present, but this time argues that this imposition of unity involves a leaving out of a multiplicity of factors. "Between two thoughts all possible affects play their game: but the movements are too quick, then we misunderstand them, we conceal them . . ." ${ }^{36}$ The need to understand things in terms of causality (and thus to understand them as things, not as processes) is in part the source of this deception, and causality itself could presumably be traced back to the dominance of a particular drive.

Thinking, then, is basically play in two senses: the play of affects and the playing together with affects. First, in a descriptive sense, Nietzsche argues that thinking, which had mistakenly been mistakenly understood as something dealing with a real world, is reducible to the interplay of our affects; it is hardly distinguishable from fantasy. This fantasy which we call thinking has, one thing in its favor: it works. By reducing processes and events to conceptual

\section{${ }^{35}$ Ibid.}

${ }^{36} \mathrm{WM}, \$ 477$, p. $332=\mathrm{WP}, \$ 477$, p. $264=\mathrm{NF}, \mathrm{VIII} / 2, \mathrm{pp} \cdot 295-96$. "Zwischen zwei Gedanken spielen noch alle möglichen Affekte ihr Spiel: aber die Bewegungen sind zu rasch, deshalb verkennen wir sie, Zeugnen wir sie..." 
unities--"things," "causes," "effects," etc.--it can create a world that it can nanage. However, in doing so it denies its own nature by thinking of itself as independent of emotion, affects, etc. This denial of its own nature may well serve the needs of life up to a point, but it also contains a weakenss. The thinking subject, by refusing to acknowledge the way in which it is related to the affects, becomes their "tool." Insofar as the person identifies himself with his thinking self, he becomes only the tool of his affects. This brings us to the second notion of play here. By recognizing that thinking is the result of the interplay and struggle of affects, the person is able to see that he is this play. Insofar as this happens, the person is then in a better position to creatively organize this interplay of forces, to engage himself activity in this creative play which is fundamentally the will to power. The way in which this is so will now be discussed in relation to Nietzsche's notion of willing. Wizling

The Critique of the Wizl. The analysis of the self in terms of play can now be extended to the notion of the will. The Nietzschean critique of the will reveals it also to be the plaything of the affects. His affirmation of willing, on the other hand, is of willing as playing together with--and creatively organizing--the play of affects.

The main lines of Nietzsche's critique of willing have already been presented in the previous chapter. Insofar as willing is dependent upon thinking, it is already clear that willing, even if it does 
take place, lacks the foundation in thinking that the will presumes it has. It is only a by-product, the "accompanying appearance of all outpourings of force." 37 The belief in willing, a belief in miracles, 38 is founded on the belief in causality, a false extension of the scientific view of the world. 39

The Affirmation of the Wizl. Willing does, however, retain meaning for Nietzsche, a meaning which is similar to his notion of thinking as play. In a fragment from 1880, he relates the feeling of freedom to an excess of strength, which leads one to act for a purpose, "but the purpose does not completely rule us; it only gives an opportunity for our strength to play with itself."40 Knowing that there will be many other such opportunities, we do not feel ourselves to be enslaved to that particular purpose. What one might call authentic willing, then, lies in giving free play to the forces within one, in which case a purpose is but the occasion for the playing out of these events. It is not the subject as a unity which wi11s, but rather the plurality of forces doing the "willing." This is in harmony with the idea that the will to power is in general willing to become

37UW, II, $\$ 720$, p. 231. ". . . Begleiterscheinung alles Ausströmens von Kraft."

${ }^{38} \mathrm{WM}, \$ 670$, p. $449=\mathrm{WP}, \$ 670, \mathrm{p} .354$.

${ }^{39}$ Ibid.

$40 \mathrm{NF}, \mathrm{V} / 1,3(48)$, p. 390. ". . aber der Zweck beherrscht uns nicht ganz, er giebt nur eine Gelegenheit, damit unsere Kraft mit sich spiele, wir wissen, es giebt noch viele andere Gelegenheiten dazu . . " 
stronger, ${ }^{41}$ but it is not the subject as such which does the willing, but rather the forces which converge in that space and time which we identify in everyday language as the subject. Such willing is an experiment. In a fragment from the time of The Down, Nietzsche argues that actually willing something is "to make an experiment in order to experience what we can do; success or failure alone will teach us about this."42 This involves a feeling of commanding or ordering: "A man who wizls commands something within himself that renders obedience." 43 This is a complex relationship in which the one who commands is also the one who obeys in certain circumstances. 44

In evaluating Nietzsche's position on the will, Arthur Danto has argued that, "There is, I think, very little of the sort of thing Nietzsche here identifies as feelings of commanding and obeying, not at least in connection with voluntary actions, so called."45 On one level Danto is correct--on the surface of things, this element of commanding does not seem to be a prominent characteristic of voluntary acts. But if the will is viewed in relation to the play of affects, as another way of ordering this play creatively, then the elements of p. 286 .

$$
41_{\mathrm{WM}}, \$ 675, \mathrm{p} .451=\mathrm{WP}, \$ 675, \mathrm{p} .356=\mathrm{NF}, \operatorname{VIII} / 2,11(96) \text {, }
$$

42 WM, II, $\$ 36$, p. 16. ". . . ein Experiment machen, um zu erfahren, was wir können; darüber kann uns allein der Erfolg oder Mißerfolg belehren."

$43_{\mathrm{JGB}}, \mathrm{I}, \S 19 ; \mathrm{VI} / 2$, p. $26=\mathrm{BGE}, \mathrm{I}, \S 19$, p. 26. "Ein Mensch, der wizz--, befieh1t einem Etwas in sich, das gehorcht . . ."

${ }^{44}$ Tbid.

${ }^{45}$ Danto, Nietzsche as Philosopher, p. 113. 
commanding and obeying become more meaningful. Willing and thinking both represent ways in which the play of affects may be organized. Again, there are two distinguishable categories of play involved here. Nietzsche's critique of the will is directed against those who, denying the relationship between the will and the affects, prevent the will from becoming free. By affirming the relationship between the will and the affects, one again opens the way for the will to become the creative force organizing these affects in its creative play. The ambiguity of the commanding-obeying relationship reflects the more fundamental ambiguity inherent in the role of the player, who is both player and plaything. 46

\section{Evaluations}

A middle term binds thinking and willing to sensation and the affects: evaluations. The argument relating willing to evaluations centers around the notion of purpose. To will involves willing something, a purpose, and this purpose contains an evaluation; 47 thus willing is always dependent upon evaluations. ${ }^{48}$ Thinking, insofar as it is necessarily a process of selection and interpretation, exhibits

46 See above, Chapter Two, pp. 24-25.

$47 \mathrm{WM}, \$ 260, \mathrm{p} \cdot 186=\mathrm{WP}, \$ 260, \mathrm{p} \cdot 150$.

48 These purposes may be fully constituted by the affects with minimal participation on the part of thinking or willing. In this case, the purpose is created by the affects--as the result of their interplay. For the free spirits, their will to power creatively transforms these in play and thus brings them under their control. 
a parallel structure: both thinking and evaluating are necessarily perspectival. 49 What today is regarded as knowledge can presumably be traced back to older evaluations. 50 so, too, even our sense impressions are shaped by our evaluations. 51

These evaluations are themselves interpretations, "a symptom of particular physiological conditions." 52 But they are not interpretations which we make; rather, it is the affects which do the interpreting. 53 This is a process which takes place in, and changes, the body. It is an experiment; valuations and consciousness, pleasure and displeasure are but signs of it. The person in which this process happens is of significance insofar as he is able to control this process. The degree to which he can do that is the degree to which he is the wil1 to power.

These valuations themselves have their foundation in the conditions of existence of particular beings, but they do not always remain perfectly in accord with them, as the case of morality shows. 54

$$
\begin{aligned}
& { }^{49} \mathrm{WM}, \S 259, \text { p. } 186=\mathrm{WP}, \S 259, \text { p. } 149 . \\
& 50_{\mathrm{WM},} \S 678, \mathrm{p} .456=\mathrm{WP}, \$ 678, \text { p. } 359 . \\
& 51_{\mathrm{WM}}, \S 260, \text { p. } 187=\mathrm{WP}, \S 260, \text { p. } 150 \text {. } \\
& 52 \text { WM, } \$ 254, \text { p. } 184=W P, \$ 254, \text { p. 148. "Die Auslegung ist }
\end{aligned}
$$
ein Symptom bestimmter physiologischer Zustände."

${ }^{53}$ Ibid.

${ }^{54} \mathrm{WM}, \S 256$, p. $185=\mathrm{WP}, \S 256$, pp. $148-49$. 
Thus we retain evaluations which are no longer precise or true, ${ }^{55}$ which have outlived their function, and these can eventually cause man's downfall. 56 Nietzsche criticizes contemporary morality precisely on this basis, because creative force and the conditions of existence are missing in it. 57 In such moralities one encounters what was originally a game. Now it has become fixed, static, and has lost its creative character. The game now dominates the players, imprisons them in its rules. The alternative to a regression to some previous morality, which in any case would appear impossible, is the development of a new kind of morality, one in which man gives himself his own goal: an experimental morality. 58 But this kind of morality is only possible if the notion of goal is defined in terms of the interplay of affects as an organic multiplicity, an interplay of forces, seeking to increase its power. In this sense, purposes arise when one lets the forces in oneself have a free play, and through the creative play of the will to power purposes are created. In this case, our evaluations are to be understood as the creative coming-to-expression of the will to power which is operative in us.

$$
\begin{aligned}
& { }^{55} \mathrm{UW}, \mathrm{II}, \S 266, \text { p. } 101 . \\
& { }^{56} \mathrm{UW}, \mathrm{I}, \$ 650, \mathrm{p} .246 . \\
& 57_{\mathrm{WM}} \text { \$260, p. } 187=\mathrm{WP}, \S 260, \text { p. } 150 \text {. } \\
& { }^{58} \mathrm{Cf} \text {. Ingeborg Heidemann, "Nietzsches Kritik der Mora1," Nie- }
\end{aligned}
$$


On the Affects and the Wizl to Power

This analysis of Nietzsche's idea of the self has led us from the phenomena of thinking and willing through the intermediate stage of evaluations down to the fundamental level of life activity: the affects or passions.

It has been shown that the relationship among these different activities may be understood as play in either of two senses. It may be play in which the affects dominate thinking and willing, making them into their playthings or it may be a creative play in which thinking and willing play together with its affects, organizing them and maximizing their power. In the latter case, the full person emerges as a player, while in the former case the person is dominated by a play which he cannot control.

In this section it wi 11 be shown that the play of affects is a structured interplay founded in an order of rank. This order of rank is a created one, the result of the creative play of the will to power. Insofar as the person is powerful, insofar as he is the will to power, he becomes the creative player who shapes his own world in his play and seeks to extend the boundaries of that play world to encompass as much as possible. The highest manifestation of this tendency, as will be shown in the following section, is the overman.

Nietzsche's analysis of the self is rooted in the body as an organic process, a multiplicity of forces which struggle with one another and generally exist in some sort of relation of dominancesubjection, and which in the affirmation of their individual existence 
also affirm the whole, ${ }^{59}$ In rooting the self in the body in this manner, Nietzsche avoids reducing the self to a thing, for the body itself is for him not a thing but a process--and Nietzsche's name for this process is the will to power. ${ }^{60}$

But what is the nature of the relationship among the affects? There is an order of rank among them, a hierarchy. In his notebooks, Nietzsche calls for substituting a perspectival doctrine of affects to replace epistemology, adding that "a hierarchy of affects" belongs to this view: "the affects transfigured; their superior order, their 'spirituality'."61 During this same period he describes man as a plurality of forces which stand in an order of rank, some commanding and others obeying. ${ }^{62}$ So, too, there is a division of labor of the affects or passions within society itself which breeds a more useful type of soul. ${ }^{63}$ Elsewhere the affects are treated as a regency rather than as a necessary unity. 64

$59_{\mathrm{UW}}, \mathrm{II}, \$ 733$, p. 236.

60 This notion of even the organic as the will to power is deve1oped as a hypothesis in JGB, II, $\$ 36$; VI/2, p. $48=$ BGE, $\$ 36$, p. 48.

$61_{\mathrm{WM},} \$ 462, \mathrm{p} .323=\mathrm{WP}, \$ 462, \mathrm{p} .255=\mathrm{NF}, \mathrm{VIII} / 2,9(8), \mathrm{p} .6$. "An Stelle der 'Erkenntnißtheorie' eine Perspektiven-Lehre der Affekte (wozu eine Hierarchie der Affekte gehört).

". . . die transfigurirten Affekte; deren höhere ordnung, deren 'Geistigkeit'."

$$
\begin{aligned}
& { }^{62} \text { UW, II, } \$ 734, \text { p. } 237 . \\
& 63_{\mathrm{WM}}, \$ 719, \mathrm{p} .486=\mathrm{WP}, \$ 719, \mathrm{p} .383=\mathrm{NF}, \operatorname{VIII} / 2,10(8), \mathrm{p} .
\end{aligned}
$$

124.

${ }^{64} \mathrm{UW}$, II, $\$ 340$, p. 124 . 
There is a unity or order among the affects and, insofar as Nietzsche presumes to speak of this order, it would appear to be knowable to some extent. But even this must be qualified. Affects are not to be considered as causes, for in this case they are but a construction of the intellect, ${ }^{65}$ as indeed are all causes for Nietzsche. We mistake, for example, the occasion of affects for their causes. ${ }^{66}$ The only type of order which would seem admissible for Nietzsche is one according to the degree of power each affect manifests. A causal ordering of the affects is a construct. If they are taken to be anything more than this, affects become errors of the intellect.

In seeming contradiction to this view of the affects, Nietzsche urges us at times to control our affects. Greatness of character consists in having powerful affects, but keeping them in line. 67 The affects are not to be overcome, but rather made to serve us.

Overcoming of the affects? No, if what is implied is their weakening and extirpation. But putting them in service: which may mean subjecting them to a protracted tyranny. . . . At last they are confidently granted freedom again: they love us as good servants and go voluntarily wherever our best interests lie. ${ }^{6}$ pp. 395-96.

$$
\begin{aligned}
& 65_{\mathrm{WM}}, \$ 670, \text { p. } 448=\mathrm{WP}, \$ 670, \text { p. } 354 \text {. } \\
& { }^{66} \mathrm{UW}, \mathrm{I}, \$ 733, \text { p. } 270 . \\
& 67_{\mathrm{WM}}, \$ 928, \text { p. } 624=\mathrm{WP}, \S 928, \text { p. } 490=\mathrm{NF}, \operatorname{VIII} / 2,11(353) \text {, }
\end{aligned}
$$

$68_{\mathrm{WM}}, \$ 384$, p. $261=\mathrm{WP}, \$ 384$, p. 207. "Überwindung der Affekte? Nein, wenn es Schwäche und Vernichtung derselben bedeuten soll. Sondern in Dienst nehmen: wozu gehören mag, sie lange zu tyrannisieren . . Endlich gibt man ihnen eine vertrauensvolle Freiheit wieder: sie lieben uns wie gute Diener und gehen freiwillig dorthin, wo unser Bestes hin wi11." 
In passages like this one, one encounters an affirmation of the individual as master of his own drives which, presumably, arises out of Nietzsche's rejection of those positions which advocate a negation of the affects. ${ }^{69}$ It seems that Nietzsche here goes beyond the limits he has established for himself. He argues in Beyond Good and Evil against the possibility of overcoming an affect insofar as this so-called overcoming is actually reducible to another affect gaining dominance. ${ }^{70}$ It would seem, however, that a similar argument is in order against his idea of taking the affects into one's service. Who or what takes them into service but another affect? Although the passage quoted above does not answer this question, there is a clear implication that the person, the individual, is in some way in control of this process; but it is precisely this which Nietzsche seems to have established as impossible within his framework. It could only be another affect which fulfills this function.

It is true that one could identify the self with a particular affect, in which case such a position would make sense from a particular standpoint, but Nietzsche would have to acknowledge that the standpoint is a falsification, for the self is a multiplicity of such affects, not simply the one which has gained ascendency. Thus, for example, he appears to distinguish between the self and its affects by saying that

${ }^{69}$ See Nietzsche's comments on the false order of rank among the affects created by Schopenhauer and others in WM, $\$ 612$, p. $417=W P$, $\$ 612$, p. $329=\mathrm{NF}$, VIII $/ 2,9(119)$, p. 68.

$70_{\mathrm{JGB}}, \mathrm{IV}, \$ 117$; VI $/ 2$, p. $93=\mathrm{BGE}, \mathrm{IV}, \$ 117$, p. 86 . 
the damage is less when the affects are let loose on others than on the self. ${ }^{71}$ Such an assertion seems to posit a self which is untenable according to Nietzsche's own criteria.

Thus the self, including its thinking and willing, is reducible to evaluations, which in turn are themselves reducible to the interplay of affects. Attempts to identify a self standing over and against this multiplicity of affects fail to overcome Nietzsche's objection that even here it is but another affect which is at work. The affects interpret, put other affects into their service--the self or the individual does not do so.

The apparent contradiction here can be resolved in terms of the category of play and the doctrine of the will to power. The will to power is the organizing principle of our affects. In a passage from one of his later notebooks, Nietzsche discusses the way in which willing in general is a willing to be stronger, adding:

. . that the most universal and basic instinct in all doing and willing has for precisely this reason remained the least known and most hidden, because in praxi we always follow its commandments, because we are this commandment. . . All valuations are only consequences and narrower perspectives in the service of this one will: valuation itself is only this will to power. 72

$$
\begin{aligned}
& 71_{\mathrm{UW}}, \mathrm{I}, \$ 857, \mathrm{p} .285 . \\
& 72_{\mathrm{WM}} \$ 675, \mathrm{p} .452=\mathrm{WP}, \$ 675, \mathrm{p} .356=\mathrm{NF}, \mathrm{VIII} / 2,11(96), \mathrm{p} .
\end{aligned}
$$
287. ". . . daß der allgemeinste und unterste Instinkt in allem Thun und Wollen eben deshalb der unerkannteste und verborgenste geblieben ist, weil in praxi wir immer seinem Gebote folgen, weil wir dies Gebot sind. . . Alle Werthschätzungen sind nur Folgen und engere Perspektiven im Dienste dieses Einen Willens: das Werthschätzen selbst ist nur dieser Wille zur Macht." 
Once again, this calls for a distinction. We are the will to power, but this can be taken in two senses. First, we can be the will to power in such a way that it dominates our willing and thinking--even if we do not recognize it. Second, we can be the will to power in such a way that our thinking and willing is the highest expression of that will to power--the dominant aspect. This introduces a new self--a multiplicity of forces organized by this creative play of the will to power. The fragment quoted above begins with a passage which describes the process we have been examining: the destruction of the traditional concept of the self and its replacement by the notion of the creative player who orders the play of affects through his will to power.

That one should take the doer back into the deed after having conceptually removed the doer and thus emptied the deed; that one should take doing something, the "aim," "intention," "purpose," back into the deed after having artificially removed all this and thus emptied the deed. 73

Through his analysis of willing and thinking as being dependent upon evaluations, which in turn are reducible to affects, Nietzsche takes the doer out of the deed, reduces it to the interplay of affects; then brings the doer back in through the notions of the free spirit, the child, the highest in the order of rank, and the overman--all of which can be subsumed under the category of the creative player. So, too,

$73 \mathrm{WM}, \$ 675$, p. $451=\mathrm{WP}, \$ 675$, p. $356=\mathrm{NF}, \mathrm{VIII} / 2,11(96), \mathrm{p}$. 286. ". . . daß man den Thäter wieder in das Thun hineinnimmt, nachdem man ihn begrifflich aus ihm herausgezogen und damit das Thun entleert hat;

". . daß man das Etwas-thun, 'das Zie1,' die 'Absicht,' den 'Zweck' wieder in das Thun zurücknimmt, nachdem man ihn künstlich aus ihm herausgezogen und damit das Thun entleert hat." 
aim, intention, and purpose have been removed from the deed by means of the same reduction; they have been shown to be illusions, after-thefact rationalizations, massive self-deceptions. Now they are re-introduced, a11 contained in one category: power. A11 deeds are done in order to increase power; they are instances of the will to power. Particular goals are set through creative play to increase that power. There is no meta-game in terms of which these individual games are to be judged. Another section of the fragment quoted above gives evidence of this. Following his statement that a11 valuations are only consequences and narrower perspectives of the will to power, Nietzsche says:

A critique of being from the point of view of any one of these values is something absurd and erroneous. Even supposing that a process of decline begins in this way, this process still stands in the service of this wizl. . .

To appraise being itself: but this appraisal itself is still this being--: if we say no, we still do what we are... . One must comprehend the absurdity of this posture of judging existence, and then try to understand what is really involved in it. It is symptomatic.

The absurdity of trying to appraise being from any one point of view lies in this: these points of view are al1 in the service of one will.

$$
{ }^{74} \mathrm{WM}, \$ 675, \mathrm{p} .451=\mathrm{WP}, \$ 675, \mathrm{pp} \cdot 356-57=\mathrm{NF}, \mathrm{VIII} / 2,11(96) \text {, }
$$
p. 287. ". . . eine Kritik des Seins aus irgend einem dieser Werthe heraus ist etwas Widersinniges und Mißverständliches; gesetzt selbst, daß sich darin ein Untergangsprozeß einleitet, so steht dieser Prozeß noch im Dienste dieses Wizlens...

"Das Sein selbst abschätzen: aber Abschätzen selbst ist dieses Sein noch--; Man muß die Absurdität dieser daseinsrichtenden Gebärde einsehen; und sodann noch zu errathen suchen, was sich eigentlich damit begiebt. Es ist symptomatisch." 
None of them offer a privileged position from which appraisal of the whole is possible. An order of rank can, however, be established according to the degree of power. While there is one will to power, it develops into many forms. 75 These forms can be ranked according to their degree of power. Such a ranking is, as was shown in Chapter Three, a creative act of the powerful. This creative ranking extends the boundaries of one will to power to encompass other, weaker instances of the will to power. This is the creative play of the powerful extending the boundaries of its created world to encompass more and more of existence. A decline may stand in the service of a more powerful instance of the will to power, but this does not overshadow the fact that it is a decline. The creative play of the powerful expands to include and dominate the play of the weak.

These powerful ones are the overmen.

On the Overman

The significance of the doctrine of the overman in Nietzsche's philosophy is an open question. Most of the references to the overman in the writings Nietzsche himself published are confined to Thus Spoke Zarathustra. There are hardly more than six or seven references to the overman after Zarathustra. 76 Commentators disagree on the importance of the concept. Jaspers devotes only a few pages to it, admitting

$75_{\text {WM }} \$ 692$, p. $468=W P, \$ 692$, p. 369.

$76 \mathrm{Cf}$. Richard Oehler, Nietzsche Register (Stuttgart: Alfred Kröner Verlag, 1965), p. 461. 
that "the image of the superman, as Nietzsche sees it, remains indeterminate." 77 Danto, discussing Zarathustra's description of the overman, maintains that it is, "divorced from the extravagant language and rushing cadences of Zarathustra's singing . . . a bland and a11-toofamiliar recomendation, rather squarely in the moralistic tradition . . to keep our passionate as well as our intellectual life in our command, not to deny one at the price of the other, and not . . be petty and 'mere1y' human."78 Both Kaufmann ${ }^{79}$ and Morgan ${ }^{80}$ equate the overman and the notion of Dionysus which develops in Nietzsche's later writings. Heidegger accords more importance to the overman, making it one of the five fundamental words in Nietzsche's metaphysics. ${ }^{81}$ He criticizes the overman because he negates the previous essence of man as reason in a nihilistic way. ${ }^{82}$ Fink also admits that the image of the overman is at first "rather indeterminate," 83 but he argues that the predecessors of the overman, which form the bridge between man and the overman, give content to this image--and the idea of the overman gives a unified form to that content. ${ }^{84}$

77Jaspers, Nietzsche, p. 166. 78 Danto, Nietasche, p. 199. ${ }^{79}$ Kaufmann, Nietzsche, p. 316.

80 George A. Morgan, What Nietzsche Means (New York: Harper and Row, 1965), pp. 301-03.

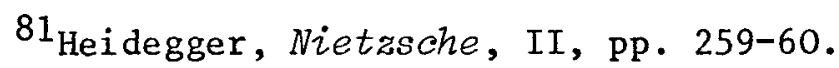

$82_{\text {Ibid. , p. } 293 .}$

${ }^{83}$ Fink, Nietzsches Philosophie, p. 69.

${ }^{84}$ Ibid., pp. 69-70. 
There is clearly room here for interpretation in regard to the importance of the concept of the overman. Other concepts, such as that of the free spirit or Dionysus, could also be used in developing an integrating image for Nietzsche's ideal. Three such images have been used in Chapter Three: the child, the free spirit, and the creators of the order of rank. Nietzsche presents in fact a multiplicity of images to describe his ideal. Among these, the overman is the most poetical and, for this reason, the one most easily subject to misinterpretation.

In this section, I shall show that the notion of the overman functions as the unifying image in terms of which both the previous images of creative play and the notion of self-overcoming can be understood. The overman is the player par excellence in existence. The overman is not a goal outside of existence, but the culmination of the creative play of the free spirit.

In Thus Spoke Zarathustra Nietzsche first presents the idea of the overman in detail. Zarathustra is the teacher of the overman, 85 who is "the meaning of the earth." 86 For man, the overman is "'the meaning of their being!." In his notebooks, Nietzsche says that, "Not humanity, but overman is the goal!" 87

Erde."

${ }^{85}$ z, "Vorrede," 3; VI/1, p. 8 = Z, "Preface," 3, p. 12.

${ }^{86}$ Ibid., p. $8=$ Ibid., p. 13. "Der Übermensch ist der Sinn der

$87_{\mathrm{WM}}, \$ 1001$, p. $658=\mathrm{WP}, \$ 1001$, p. 519. "Nicht 'Menschheit,' sondern Ubermensch ist das Ziel." 
The descriptions of the overman have a religious dimension that seems quite intentional. The very name of Zarathustra evokes the image of Zoroaster and his religion. The tone of Zarathustra hints at shades of John the Baptist preparing the way for the savior. Other passages indicate that the overman is to take God's "place." (The qualification implied by the quotation marks here is this: God's place may simply be eliminated and the overman may take up a different place, one which is not outside of human history.) Thus we are told, now that all the gods are dead, long live the overman. 88 When one used to say "God" when looking out over distant seas, now he is to say the name of the overman. 89 With God dead, the higher men wish that the overman might live. 90 In his notebooks, Nietzsche refers to the overman as "a completely epicurean God . . the one who transfigures existence. $" 91$

It is difficult not to be mistrustful of such statements, especially in the light of Nietzsche's own critique of Christianity and religion in general. Certainly he is not trying to start another

$88_{Z}$, I, "Von der Schenkenden Tugend," 3; VI/1, p. $98=\mathrm{Z}, \mathrm{I}$, "On the Gift-giving Virtue," 3, p. 79.

${ }^{89} \mathrm{Z}$, II, "Auf den glückseligen Inseln;" VI/1, p. $105=\mathrm{Z}$, II, "Upon the Blessed Isles," p. 85.

$90 \mathrm{Z}$, IV, "Vom höheren Menschen," 2; VI/1, p. $353=\mathrm{Z}$, IV, "On the Higher Man," 2, p. 287.

${ }^{91} \mathrm{UW}$, II, $\$ 1409$, p. 507. "Die Rangordnung, durchgeführt in einem System der Erdregierung; die Herren der Erde zuletzt, eine neue herrschende Kaste. Aus ihnen hier und da entspringend, ganz epikurischer Gott, der Übermensch, der Verklärer des Daseins." 
religion; he is not looking for disciples, but rather for equals. Nonetheless, the overman is somewhat problematic. Nietzsche would make great sacrifices for him; he would suffer anything to reach the overman for on1y a moment..$^{92}$ To bring about the emergence of the overman, he would offer up himself and others. ${ }^{93}$ These and similar remarks suggest a denial of one's existence in the moment, a sacrificing of the moment to bring about a future redemption, which is characteristic of the religious consciousness. Indeed, one could offer a counter argument: this sacrificing is really only being what one is, being one who prepares the way for the overman by participating in the se1f-overcoming of man. ${ }^{94}$ Consequently it is not a denial of existence, but rather its affirmation.

Additional problems arise from Zarathustra's contention that, "Never yet has there been an overman."95 Nietzsche's own argument against a final goal of becoming--if the world had a goal, it would have been reached by now 96 --seems equally valid in relation to the

$$
\begin{aligned}
& \text { 92 UW, II, } \$ 1260, \text { p. } 453 . \\
& 93_{\mathrm{UW}} \text {, II, } \$ 1211, \text { p. } 445 . \\
& { }^{94} \mathrm{Cf} \text {. Eugen Fink, Nietzsches PhiZosophie, p. 69. "Der Mensch }
\end{aligned}
$$
ist ein sich selbst überwindendes Wesen, weil in ihm das allgemeine Wesen des Lebens überhaupt, der Wille zur Macht, sich selbst erkennt, bzw. erkennen kann."

$95 \mathrm{Z}$, II, "Von den Priestern;" VI/1, p. $115=\mathrm{Z}$, II, "On Priests," p. 93. "Niemals noch gab es einen Übermenschen."

$96_{\mathrm{WM}}, \$ 55$, p. $44=\mathrm{WP}, \$ 55$, p. 36 . "Wir leugnen Sch1uß-Ziele: hätte das Dasein eins, so müßte es erreicht sein." Here I am following Ivan Soll's interpretation of this fragment: "According to the argument, given an infinite amount of time in the past and a finite number 
overman: if the overman were going to appear, he would have appeared by now. But nowhere does Nietzsche maintain that the overman has already appeared, except perhaps in that passage from Ecce Homo on Zarathustra, where it is implied that in Zarathustra's interactions with men man is overcome at every moment, that "the concept of the 'overman' has here become the greatest reality."97 But Zarathustra can be said to exist only in a very qualified sense, as a poetic creation. The overman's coming seems in general to be an event which Nietzsche seeks as happening in the future. It is precisely the futurity of the overman which allows it to be a unifying concept. It pulls together the many different images considered so far--the child, the free spirit, the creators of the order of rank--and focuses them in one image: the overman. The overman is the symbol which represents the culmination of these developments. This is not a goal outside of the course of history, a final goal of the world, but rather the symbol of the highest reaches of man's process of self-transcendence, the goal which man sets for himself.

The last man is characterized by his desire to avoid all deviation from the norm, all exertion. Zarathustra describes him in the

of possible states of the universe, every state, that will occur in the future has already recurrent in the past." "Reflections on Recurrence: A Re-examination of Nietzsche's Doctrine, Der Ewige Wiederkehr des Gleichen," in Nietzsche. Critical Essays, p. 330.

97 $\mathrm{EH}$, "Also sprach Zarathustra," 6; VI/3, p. $342=\mathrm{EH}$, "Thus Spoke Zarathustra," 6, p. 305. "Hier ist in jedem Augenblick der Mensch überwunden, der Begriff 'Übermensch' ward hier höchste Rea1ität." 
following terms. "No shepherd and one herd! Everybody wants the same, everybody is the same: whoever feels different goes voluntarily into a madhouse." 98 While they can be said to be playing, it is clear that they are not doing so consciously or creatively. Their game has come to dominate them. They shrivel up and wait for it to end.

The meaning of the overman can be seen more clearly by concentrating on the tendencies in existence to which it calls attention. The overman represents a sharpening of contradictions and tensions in existence, which results in the opposite of the overmen: the "1ast men". 99 Two other characteristics belong to the emergence of the overman. His coming brings about the greatest increase in his consciousness of strength. ${ }^{100}$ Indeed, insofar as an increase in power is associated with a greater struggle, the highest instance of power--the overman--necessitates the greatest tension--that between the overman and the last men. Finally, the entire process under discussion here involves the overcoming of man. 101

But just what is meant by "man" here? One fragment suggests that it is the species man which is to be overcome, 102 but the entire

98Z, "Vorrede," 5; VI/1, p. $14=$ z, "Prologue," 5, p. 18. "Kein Hirt und Eine Heerde! Jeder will das Gleiche, Jeder ist gleich: wer anders fühlt, geht freiwillig in's Irrenhaus."

$$
\begin{aligned}
& { }^{99} \mathrm{UW}, \mathrm{II}, \S \S 1211,1212, \text { p. } 445 . \\
& 100_{\mathrm{WM}}, \$ 1060, \mathrm{p} .691=\mathrm{WP}, \$ 1060, \mathrm{p} .546 . \\
& 101_{\mathrm{Z}} \text {, IV, "Vom höheren Menschen," } 3 ; \mathrm{VI} / 1, \mathrm{p} .353=\mathrm{Z} \text {, IV, "On }
\end{aligned}
$$
the Higher Man," 3, p. 287.

$$
{ }^{102} \mathrm{UW}, \mathrm{II}, \$ 1211, \text { p. } 445 .
$$


thrust of Nietzsche's writings suggests a more adequate formulation: the "man" that is to be overcome is everything in man which Nietzsche has criticized. The preceding sections of this chapter have shown the specific ways in which this overcoming is brought about in relation to willing, thinking, evaluating, sensing, and the play of affects. This is the fullness of Nietzsche's notion of self overcoming: the affects, sensations, evaluations, thinking and willing are brought together in the creative play of the will to power. The overman symbolizes the culmination of this process. It is not, as Heidegger maintains, a nihilistic overcoming only of thought. 103 Nor need it remain vague. The notion of overcoming in and through creative play, as presented in the preceding sections of this chapter, gives this overcoming specific content.

There is one final aspect of the notion of the overman: his realization that everything recurs, 104 the eternal recurrence of the same. The way in which the eternal recurrence of the same completes Nietzsche's philosophy of creative play is the final problem to be considered in this work, the topic of the final chapter. Conclusion

The result of Nietzsche's critique of thinking, willing, eva1uating and sensations was to reduce the self to the interplay of the affects, which effectively removed the doer from the deed. This left

$$
\begin{aligned}
& { }^{103} \text { Heidegger, Nietzsche, II, p. } 293 . \\
& { }^{104} \text { UW, II, } \$ \$ 1384,1385,1387, \text { p. } 500 .
\end{aligned}
$$


the way open to a reinterpretation of the deed as a particular instance of the one will to power and a reconstitution of the self as the overman. The idea of the overman restores a unity to the self which had been destroyed in Nietzsche's critique, but this unity is of a very qualified type. "A11 unity is unity only as organization and interplay."105 The overman possesses unity only in the sense that he organizes the interplay of forces which are his affects through the will to power. Thus there are two ways in which the self is play in Nietzsche. The self may be the plaything of the affects, in which case they control him. This is the mark of weakness, the absence of the will to power. Alternately, the self may creatively organize and control this interplay through the will to power, in which case the entire self--including the affects, evaluations, thinking and willing --is a creative playing which seeks to extend itself. This two-fold meaning of play has been analyzed on several levels--on the level of willing, thinking, evaluating, sensing and the affective level. This lays the foundation for a unified self where the overcoming of the self on all levels is accomplished through creative play. The overman is the highest symbol of this process.

It now remains to extend this interpretation to the doctrine of the eternal recurrence of the same.

105WM, $\$ 561$, p. $383=\mathrm{WP}, \$ 561$, p. 303. "Alle Einheit ist nur als Organisation und Zusammenspiel Einheit." 


\section{CHAPTER SIX}

THE ETERNAL RECURRENCE AND THE PLAY OF FORCES:

TEMPORALITY AND PLAY

\section{Introduction}

In the last three chapters, the category of play in Nietzsche's philosophy has been developed on three levels: as the highest form of human activity, the creative play of the free spirits (Chapter Three); as the hidden meaning of morality, the game of self-deception (Chapter Four); and as constitutive of the self in the interplay of affects as shaped through the will to power. It now remains to consider the most fundamental level on which play is encountered in Nietzsche's philosophy: the eternal recurrence of the same. The following analysis of the doctrine of the eternal recurrence of the same will show that this doctrine yields a picture of the cosmos as fundamentally an interplay of forces, eternally creating and destroying, without end in either of two senses--without a final goal or purpose, and unending in time.

By showing that the eternal recurrence of the same is essentially a picture of the universe as an interplay of forces, this analysis will have been completed. It will have been shown that the category of play is the fundamental one in terms of which all of existence is to be understood for Nietzsche. At the same time, it will be shown that 
this category shifts in meaning. In relation to the free spirits, play was considered as a free creative activity through which and in which the free spirit makes his own world, continually seeking to enlarge its boundaries to encompass other play worlds. The category of play in morality was somewhat different, for the moral ones did not realize that they were only playing; their game was the self-deceptive game of the mediocre, the herd. Through an analysis of human action in relation to its knowability, purposefulness and foundation in free will, it was possible to show that moral actions could be nothing but play, but a play in which the player deceives himself into thinking that he is doing something other than playing and in which he limits his own power in favor of the mediocre, the suffering ones, the herd. In considering the self as the interplay of affects, it became clear that this play was even less under the control of a player than the two previous forms. These forces are still free, not bound to any final goal or order of things in themselves, but the person is less conscious of the dimensions of this interplay of affects. Thus the meaning of the category of play in these last three chapters has been shifting steadily from human play to the play of forces beyond human control.

The doctrine of the eternal recurrence of the same completes this movement insofar as play now becomes the play of forces which is completely beyond human control--a cosmic play. ${ }^{1}$ However, it is

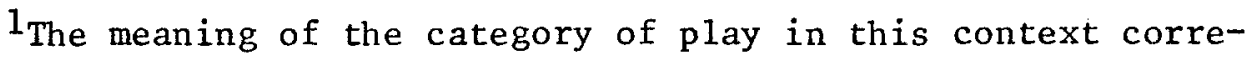
sponds in general to that elaborated by Ingeborg Heidemann in her 
possible to show that the movement does not stop here with the least human level of play. It will be argued that the eternal recurrence of the same is not a doctrine which refers to things in themselves, but itself is the expression of the play character of human existence which creates this doctrine. Cosmic play--as expressed in the doctrine of the eternal recurrence--reveals itself to be the result of human play. This argument, which will be developed in detail below, will show that Nietzsche's philosophy is not, as Karl Löwith has maintained, characterized by a fundamental contradiction. ${ }^{2}$ It will be shown in this chapter that, when they are interpreted in terms of the category of play, the main tenets of Nietzsche's philosophy do not lead to fundamental contradictions. The apparent contradictions in Nietzsche's

discussion of the four-fold definition of the concept of play in Kant: ". . das Spiel als die Anordnung, in der keine Absicht ist. Diese Alternative könnte so aufgefaßt werden, als ob sie der ersten terminologischen Festlegung widersprechen würde, nach der die Spielhandlung zwar zweckfrei oder zwecklos ist, aber eine Absicht hat. Die Unterscheidung hängt jedoch $a b$ von dem Standpunkt, unter dem die Anordnung betrachtet wird: als Handlung, als Form, als bestimmte Koordination, als Ordnung überhaupt; oder auch, im Aspekt der Handlung: in bezug auf den Anfang oder das Ende, oder in bezug auf den Verlauf. So wird an anderer Stelle das Spiel als 'Beschäftigung ohne Absicht' damit begründet, daß es nicht 'am Ende' vergenügt, sondern während seiner Dauer gefällt."

Der Begriff des Spieles, p. 161. Play here is used in the sense of a free ordering of forces which is not intended to achieve any final goal.

${ }^{2}$ Cf. Kar1 Löwith, Nietzsches Philosophie der Ewigen Wiederkehr des Gleichen (Stuttgart: Kohlhammer, 1956), p. 14, where Löwith maintains that, "ein wesentlicher und umfassender [Widerspruch], der einem Grundkonflikt in Verhältnis von Mensch und Welt--ohne Gott und gemeinsame Schöpfungsordnung--entspringt . . ." characterizes Nietzsche's philosophy. 
philosophy can be resolved in terms of the category of play, which functions as the unifying insight of Nietzschean philosophy.

The argument of this final chapter is somewhat complex. First, the context for Nietzsche's doctrine of the eternal recurrence will be developed: the problem of temporality. Four problems face Nietzsche in regard to temporality: how to affirm the past, the relationship between being and becoming, the adequacy of traditional concepts of time, and the possibility of creatively willing time. The eternal recurrence of the same is a response to these four areas of problems; it culminates in the notion of creatively willing time through the affirmation of the eternal recurrence of the same. This is the subject of the second part of this chapter: the meaning of the eternal recurrence and the modes in which it is affirmed. It is necessary, in particular, to consider what Nietzsche means by naming, thinking and willing the eternal recurrence, for it is here that we see that the eternal recurrence is the expression of the free spirit's--or at least Nietzsche's--creative play. In other words, it will be shown that the eternal recurrence is play in two senses. First, the picture of the cosmos which it yields is basically that of a cosmos as the play of forces. Second, the creation of this picture is itself an act of play, playful naming, thinking, and willing.

Having shown the two senses in which the eternal recurrence is play, it will be shown how the notion of the eternal recurrence resolves the four areas of problems in regard to the question of temporality which were outlined at the beginning of this chapter. The chapter then concludes with a consideration of Nietzsche's final 
vision of the world as play, emphasizing the unity of the Nietzschean position.

A. The Framing of the Question of Temporality

The meditation on time arises out of four fundamental areas of concern. First, time is something to be overcome as time past, as the "it was." Second, time must be affirmed within the context of the struggle between being and becoming. Third, the ideas of time in traditional interpretations of the world, both Christian and polytheistic, must be surpassed. Finally, time must be willed in a radically new way if man is to be truly creative, and if life as continuous self-transcendence is to become possible.

Time Past: The "It Was"

The first problem is posed most clearly in Zarathustra's speech on redemption. ${ }^{3}$ Redemption can only be attained by a transförmation of the "it was" into a "thus I willed it." Time paralyzes the will because the "it was" cannot be affirmed. It is this which gives rise to revenge, the "will's ill will against time and its 'it was'." 4 It is revenge which leads to looking upon time as that which must devour its children--indeed, it has even led us to positing this as the basic law of time, its justice. 5 tion," p. 139 .

${ }^{4}$ Ibid., p. $176=$ Ibid., p. 140. "Diess, ja diess allein ist Rache selber: des Willens Widerwille gegen die Zeit und ihr 'Es war'."

${ }^{5}$ Ibid. 
The will must be relieved of the folly of revenge; it must be taught to will even the frightful accident of the past. Zarathustra presents the creative will as the answer to the "it was," establishing the context of a possible solution. The past is transformed, brought under our control, by willing it again in the future. However, this still leaves a problem: "to work on the future and redeem with their creation all that has been" 6 is again to turn time against us, to create a division between the moment and that which is yet to happen. The final folly which we shall uncover here is not revenge, but the will itself. Insofar as man wills, he puts himself outside himself in time, subjecting himself to the tyranny of time's control over events beyond his reach.

Being and Becoming

Second, the problem of time is framed within the context of the tension between being and becoming. The difficulty to which the previous consideration leads--the impossibility of escaping the tyranny of time while one is still willing something--exists on the level of the individual. The corresponding problem, on the level of the world itself, is the impossibility of a final state of the world. Zarathustra has stated the need to praise all impermanence, ${ }^{7}$ and the notes in The

${ }^{6} \mathrm{Z}$, III, "Von alten und neuen Tafeln," 3 ; VI/1, p. $245=\mathrm{Z}$, III, "On the 01d and New Tablets," 3, p. 198. ". . . an der Zukunft schaffen, und Alles, das war--, schaffend zu erlösen."

$7 Z$, II, "Auf den glückseligen Inseln;" VI/1, p. $106=Z$, II, "On the Blessed Isles," pp. 86-87. 
Wilz to Power shed more light on this.

Becoming must be explained without recourse to final intentions; becoming must appear justified at every moment (or incapable of being devalued; which amounts to the same thing); the present must absolutely not be justified by reference to a future, nor the past by reference to the present. 8

We must not admit of anything with being least the world of becoming be devalued. 9 The primacy of the moment, which is also stressed in Zarathustra, ${ }^{10}$ implies a fundamental rejection of any final state. All moments are of equivalent value.

A rather unusual argument is advanced in support of the position that the world has no final state or goal. It, too, is to be found in The Wizl to Power.

If the world had a goal, it must have been reached. If there were for it some unintended final state, this also must have been reached. If it were in any way capable of a pausing and becoming fixed, of "being," if in the whole course of its becoming it possessed even for a moment this capability of "being," then a11 becoming would long since have come to an end, along with all thinking, al1 "spirit."11

${ }^{8}$ WM, $\$ 708, \mathrm{p} .479=\mathrm{WP}, \S 708, \mathrm{p} .377=\mathrm{NF}, \mathrm{VIII} / 2,11(72), \mathrm{p}$. 276. ". . - das Werden soll erklärt werden, ohne zu solchen finalen Absichten Zuflucht zu nehmen: das Werden muß gerechtfertigt erscheinen in jedem Augenblick (oder unabwerthbar: was auf eins hinausläuft); es darf absolut nicht das Gegenwärtige um eines Zukünftigen wegen oder das Vergangene um des Gegenwärtigen willen gerechtfertigt werden."

$$
{ }^{9} \mathrm{NF}, \operatorname{VIII} / 2,11(72), \text { p. } 277 .
$$

$10_{Z}$, III, "Von Gesicht und Räthsel," 2; VI/1, p. $196=$ Z, III, "On the Vision and the Riddle," 2, p. 158.

$11_{W M}, \$ 1062, \mathrm{p} .692=\mathrm{WP}, \$ 1062, \mathrm{p} .546$. "Hätte die We1t ein Ziel, so müßte es erreicht sein. Gäbe es für sie einen unbeabsichtigten Endzustand, so müßte er ebenfalls erreicht sein. Wäre sie überhaupt eines Verharrens und Starrwerdens, eines 'Seins' fähig, hätte sie in a1lem ihrem Werden nur Einen Augenblick diese Fähigkeit des 'Seins,' so wäre sie wiederum mit allem Werden längst zu Ende, also auch mit allem Denken, mit allem 'Geiste'." 
These arguments, especially the first, could also be used against Nietzsche's idea of the eternal recurrence of the same, just as they could be used against his concept of the overman. ${ }^{12}$ If the same is taken in the sense of some being, entity or stability which exists in itself and recurs eternally, ${ }^{13}$ then one can argue against Nietzsche that, if the same is to recur over and over again, one would expect to have found evidence of this--it must have done so by now. Clearly it has not. Yet what conclusion can we draw from that? It is possible to say that this simply shows that Nietzsche is wrong--perhaps even a fool to maintain such an obviously false doctrine. ${ }^{14}$ One could say

${ }^{12} \mathrm{Cf}$. above, Chapter Five, pp. $168 \mathrm{f}$.

13 Few of the English or American commentators consider the question of what it is that returns eternally the same by also considering Nietzsche's idea of sameness. Arthur Danto, for example, does not really take up the question at all, but he considers such possibilities as "the world," fossils and things in general, and states of energy-but without trying to discover precisely what it is that returns the same. (Cf. Nietzsche as Philosopher, pp. $204 \mathrm{ff.}$ ) Walter Kaufmann generally considers the eternal recurrence to refer to events, but at times interprets it as the "doctrine of the eternal recurrence of all things." (Cf. Nietasche: PhiZosopher, Psychologist, Antichrist, p. 320.) It is not things which recur, and in this chapter it will be shown that the doctrine of the eternal recurrence is best understood in relation to the Nietzschean notion of sameness, which will be elaborated below.

${ }^{14}$ Commenting on what he considers to be the three main theses in Nietzsche's philosophy--which include the eternal recurrence--Walter Bröcker maintains: "Diese Lehre bleibt nicht nur ohne Beweis und ohne Wahrheit, sie ist überhaupt nicht ernst zu nehmen und insofern Narrheit. In diese Narrheit fällt aber Nietzsche nicht, weil er ein Narr sein oder den Narren spielen will, sondern gegen seinen Willen, als Opfer seiner philosophischen Unbildung." ("Nietzsches Narrentum," in Nietzsche Studien, Band I, p. 142.) As will be shown below, Nietzsche's notion of the eternal recurrence of the same is not without proof or truth, although the question of the foundation of this proof remains to be determined. 
that Nietzsche meant something else by "the same" than the sense defined above. One could also say that his notions of thinking and proving the eternal recurrence are radically different from what we usually understand these notions to entail. In fact, both these alternatives are true. First, Nietzsche does not mean that the same beings, entities or stability continually recurs. His notion of sameness, which will be elaborated below, is quite different from this and far more complex. Second, his notions of naming, thinking and willing eternal recurrence introduce modes for affirming the eternal recurrence which allow him to escape the criticisms made above. The ways in which this happens will be discussed below in the sections dealing with the concept of "the same" and with the naming, thinking and willing of the eternal recurrence of the same.

Traditional Concepts of Time

The question of time emerges from two different traditions. On the one hand, there is the Christian tradition which has established the question of time as one of eternity. Christianity, by enlarging the sinfulness of every individual to cosmic proportions, established eternal perspectives around man, teaching him to see himself as something past. 15 The way in which we conceive of time will be in part rooted in the tendency to see ourselves from afar, to put ourselves in eternal perspectives. In such a framework, it is easy to imagine time as devouring her children.

$$
{ }^{15} \mathrm{FW}, \mathrm{II}, \S 78, \mathrm{p} .93=\mathrm{JW}, \mathrm{II}, \S 78, \mathrm{p} .110
$$


Juxtaposed to this is the free-thinking which is rooted in polytheism. It established the image of a free and ever-creative man for whom there are no eternal horizons and perspectives. 16 The absence of eternal horizons signals the dawn of a new world, an open sea that never existed before. 17

Both traditions must be surpassed. Insofar as the Christian interpretation posits one meaning, devalues the world of becoming, and emaciates the power of the individual, it must be set aside. Insofar as the multi-perspectivism of polytheism leads to a thinking of infinite possibilities (not simply unlimited time, but also unlimited space and force), it posits a newness to which the eternal recurrence is opposed. These infinite horizons provide the background for the creative play of the free spirits, which will give them shape and meaning. A new way of thinking about temporality, going beyond both these traditions, is necessary. Creative wizling of Time

The fourth aspect of the problematic of temporality is Nietzsche's philosophy is his demand that creativity yield a new attitude toward the problem of time. It has been shown that the will was presented by Zarathustra as the great liberator. Leaving aside for the moment the question of who it is that does the liberating, we may recall that it is not enough just for man to be free. Zarathustra

$$
\begin{aligned}
& 16 \mathrm{FW}, \text { III, } \$ 143, \text { p. } 151=\mathrm{JW}, \$ 143, \mathrm{p} \cdot 180 . \\
& 17 \mathrm{FW}, \mathrm{V}, \S 343, \text { p. } 236=\mathrm{JW}, \mathrm{V}, \$ 343, \text { p. } 276 .
\end{aligned}
$$


poses the question of freedom not in terms of that from which man is free, but rather in terms of the much more important question: free for what? ${ }^{18}$ As is clear from the preceding consideration of the will to power, ${ }^{19}$ the answer to this question is an increase in power. The question of freedom is then transformed into the issue of power and its exercise. 20

That the relationship between self-affirmation and the will to power is a problematic one which seems to demand simultaneously the affirmation and destruction of the self is clear from the preceding chapter. The specifically temporal dimension of this problem is to be found in the necessity for some sort of temporal distance in willing between the moment in which something is willed and that in which it is achieved. This points to the more general problem of the distance between the one willing and that which is willed. The possibility of complete self-affirmation becomes a real one only if time is not only overcome--in the sense that the tyranny of the "it was" is eliminated--but also reoconstituted. Time must not simply be escaped from, but must be affirmed in a radically new manner, in terms of power and force.

The four-fold problem of time as it is outlined here will find its overcoming within the thinking of the eternal recurrence of

$18 \mathrm{Z}, \mathrm{I}$, "Vom Wege des Schaffenden;" VI/1, p. $77=\mathrm{Z}, \mathrm{I}$, "On the Way of the Creator," p. 63.

${ }^{19}$ See above, Chapter Four, pp. $129 \mathrm{ff}$. $20_{\mathrm{WM}}, \S 859$, p. $582=\mathrm{WP}, \S 859$, p. 458 . 
the same; time will be given a new and positive affirmation in Nietzsche's thinking about play. The following sections will consider the meaning of the doctrine of the eternal recurrence, the way in which it allows man to escape the tyranny of time, and the reconstitution of time through play. Thus the following two parts give Nietzsche's answer to the first three aspects of the problem of time, while the fourth part of this chapter is concerned with the final aspect of the problem.

\section{B. The Eternal Recurrence of the Same}

In attempting to determine the meaning of the eternal recurrence of the same, I shall first consider some oblique references to the doctrine which establish the context and development of the problem. Second, it will be shown that the eternal recurrence is not one that involves a naive understanding of physical law as referring to the order of things in themselves. Third, the meaning of the eternal recurrence will be considered within the context of force and power. Fourth, the primacy of power will be shown to be fundamental to Nietzsche's position on the eternal recurrence. Fifth, the meaning of "the same" and its relation to willing and power will be explicated. These considerations establish the necessary framework within which the main theme can be considered: the thinking and naming of the eternal recurrence of the same and, following this, the willing of the eternal recurrence. The section will conclude with a consideration of the primacy of praxis, showing how this enables us to understand the eternal recurrence as the most horrible and the most liberating of thoughts. 
Oblique References to the Eternal Recurrence

Before turning to a consideration of the doctrine of the eternal recurrence itself, I shall discuss certain oblique references to this idea. First, it will be shown that Nietzsche's reflections on monumental history contain a notion of sameness which anticipates the one encountered in the doctrine of the eternal recurrence of the same; moreover, these reflections imply a cosmological doctrine of recurrence. Second, it will be shown that the eternal recurrence is presented as "a thought," a terrifying possibility, in "The Heaviest Burden." This early (1882) formulation of the doctrine of the eternal recurrence reveals its terrifying character and raises the question-which will be answered in the sections on the naming, thinking and willing of the eternal recurrence--of whether the eternal recurrence is merely a thought or whether it is something more. In addition to this, it suggests the first meaning of what it is that recurs eternally the same: every aspect of one's life. The last part of this section considers some passages from Nietzsche's notebooks which suggest a second hypothesis in regard to the question of what returns the same: the continual creating of new worlds.

In his essay, "On the Use and Abuse of History," Nietzsche takes up the problem of time within the context of forgetting, It is the power to forget which is the condition of overcoming becoming and of the establishment of the primacy of the moment. This power of forgetting, or of feeling "unhistorically," is a necessary property of all action, one which we see prevents man from losing himself in 
the stream of becoming. 21

At this point in Nietzsche's development, there still remains a greater emphasis on the individual. Insofar as the individual is to be maintained, becoming stands as a threat because the individual demands permanence. The thinking of monumental history ${ }^{22}$ is a means of giving sameness by showing the possibility of recurrence. 23 However, if monumental history is a means of overcoming time, it remains at this stage a problematic means.

First, the notion of monumental history yields the courage for such overcoming only at the expense of doing violence to the past. It is necessary to impose "sameness" on the past in order that comparisons with the past can have binding-power. 24 But this forces the individuality of the past into general formulae, destroying its uniqueness. Such an imposition is problematic for Nietzsche at this point, and would remain so until the notion of sameness had been clarified, because it does do violence to the past, destroying some of its uniqueness.

Second, a cosmological position is already implied in the consideration of monumental history as the necessary condition of the

21 "Vom Nutzen und Nachtei1 der Historie für das Leben," $\$ 1$, in Unzeitgemässe Betrachtungen (Stuttgart: Alfred Kröner Verlag, 1964), p. 103. Hereafter abbreviated as UB, II, followed by the section and page numbers. history.

${ }^{22}$ Cf. UB, II, $\S 2$, p. 113 for Nietzsche's definition of monumental

$$
\begin{aligned}
& { }^{23} \text { Ibid., p. } 114 . \\
& { }^{24} \text { Ibid., p. } 115 .
\end{aligned}
$$


attainment of the complete truth of monumental history. This allows a partial reconciliation of sameness and uniqueness.

On1y if the earth always began its drama after the fifth act, and it were certain that the same interaction of motives, the same deus ex machina, the same catastrophe would recur at particular intervals, could the powerful desire monumental history in its full archetypic truthfulness, i.e. each fact set out precisely in its peculiarity and uniqueness. . . Until then monumental history will never be able to make use of complete truthfulness; it will always bring together things that are not the same, generalize them, and make them the same; it will always weaken the difference between motives and occasions in order to depict effects at the expense of causes--monumentally, i.e., as examples for imitation. It disregards causes as much as possible, and might with less exaggeration be called a collection of "effects in themselves," than of events that will have an effect on all ages. 25

This passage is significant for two reasons. It indicates the cosmological dimensions of the problem of sameness, and it also shows that this endeavor involves the overcoming of the category of causality, searching rather after "effects in themselves." Nietzsche refers in this same section to the Pythagorean view of the world as a presupposition of such a notion of history, ${ }^{26}$ and there is indeed evidence that

\section{${ }^{25}$ Ibid., p. 115. "Nur wenn die Erde ihr Theaterstück jedesmal} nach dem fünften Akt von neuem anfinge, wenn es feststünde, daß dieselbe Verknotung von Motiven, derselbe deus ex machina, dieselbe Katastrophe in bestimmten Zwischenräumen wiederkehrten, dürfte der Mächtige die monumentale Historie in voller ikonischer Wahrhaftigkeit, daß heißt jedes Faktum in seiner genau geschilderten Eigentümlichkeit und Einzigkeit begehren . . Bis dahin wird die monumentale Historie jene volle Wahrhaftigkeit nicht brauchen können: immer wird sie das Ungleiche annähern, verallgemeinern und endlich gleichsetzen; immer wird sie die Verschiedenheit der Motive und Anlässe abschwächen, um auf Kosten der causae die effectus monumental, nämlich vorbild1ich und nachahmungswürdig, hinzustellen: so daß man sie, weil sie möglichst von den Ursachen absieht, mit geringer Übertreibung eine Sammlung der 'Effekte an sich' nennen könnte, als von Ereignissen; die zu allen Zeiten Effekt machen werden."

$$
{ }^{26} \text { Ibid. }
$$


the Pythagoreans held a notion of the eternal recurrence of the same on the level of the cosmos as well as in human history. 27 The passage is also of interest because it indicates another usage of play in Nietzsche's philosophy: the understanding of history in terms of a theater play. 28

There is, then, in the consideration on monumental history the beginning of a meditation upon the problem of time and the eternal recurrence. Many of the essential components of later formulations of the problem are already present: the threat of becoming, the inadequacy of the categories of cause and effect, the primacy of interpretation, the problematic character of "the same," the need to frame the eternal recurrence in terms which stretch beyond the individual to human history itself and to the cosmos. The notion of play is already

${ }^{27}$ Cf. W. K. C. Guthrie, A History of Greek PhiZosophy, Volume One (Cambridge: Cambridge University Press, 1962), pp. 279-80.

${ }^{28}$ In the first section of "On the Use and Abuse of History," the image of the playing child--reminiscent of the discussion of Heraclitus as we11 as of "On the Three Metamorphoses" in Zarathustra-recurs. Man with the burden of the past is compelled, as if looking upon some lost paradise, "das Kind zu sehen, das noch nichts Vergangenes zu verleugnen hat und zwischen den Zäunen der Vergangenheit und der Zukunft in überseliger Blindheit spielt. Und doch muß ihm sein Spiel gestört werden: nur zu zeitig wird es aus der Vergessenheit heraufgerufen." (UB, II, $\$ 1$, p. 102.) Note that it is the imposition of real time which brings about the destruction of the child's game ("real time" here being "historical time"), while it was his ability to forget history and its time which made such playing first possible.

The category of play in regard to history also arises as the interplay of historical forces. For example, in his notebooks from 1875, Nietzsche writes of the interplay between Alexandrianism and Christianity: ". . das rhythmische Spiel der beiden Faktoren gegen einander, an dem die Welt zu leiden hatte." (NF, IV/1, 11(22), p. 284.) 
present here, and the relation between play and temporality has already been hinted at. The central notion, that which will be used to overcome many of the problems here, is still to be developed at this stage: the will to power.

In the passage on "The Heaviest Burden," a theme is introduced which will enlarge the notion of the eternal recurrence: the power of the "thought" of the eternal recurrence. The demon introduces this terrifying thought, suggesting that the eternal recurrence would be the heaviest burden on one's activity, an eternal sanctioning and sealing. ${ }^{29}$ Two points should be noted here.

First, it is the "unspeakably small and great" of life which recurs. This indicates that every aspect of one's life recurs. ${ }^{30}$ Asking the question of what it is that recurs eternally, we have the first possible answer: every aspect of one's life, including the unspeakably small and great.

Second, the theory is not presented as a "fact"--the meaning of a "fact" will be discussed below--but rather as a "thought." What is significant at this point is the possibility of the eternal return,

$$
{ }^{29} \mathrm{FW}, \mathrm{IV}, \$ 341, \text { p. } 231=\mathrm{JW}, \mathrm{IV}, \$ 341, \text { p. } 270 .
$$

${ }^{30} \mathrm{Cf}$. Ivan Soll, "Reflections on Recurrence: A Re-examination of Nietzsche's Doctrine, Die Ewige Wiederkehr des Gleichen," in Nietzsche: A Collection of Critical Essays, p. 340. This does not necessarily entail the problem Soll poses when he states: "A person can have no direct memories of earlier recurrences. If he did, the increment of his mental life would make him different from his predecessors and hence not an identical recurrence of them." While this is true in relation to the past, once one does have the thought, then it is clear that in the future one will recur with the knowledge that one will recur in the future again. 
the thinking of the eternal recurrence 31 Again, this will be considered in more detail below. Suffice it to note the way in which the eternal recurrence is advanced at this point.

Several other oblique references to the problem of the eternal recurrence are to be found in the fragments collected in The Wilz to Power, and a short consideration of them will conclude this treatment of indirect and preliminary statements of the eternal recurrence.

In discussing the contrast between Apollo and Dionysus in 1885-86, Nietzsche suggests that Apo11o's deception is the eternity of the beautiful form, while the enjoyment of Dionysus' life is rooted in the continual creativity of productive and destructive force. $32 \mathrm{~A}$ similar contrast is developed later (Spring-Fa11, 1887), and it is clear that Nietzsche is not arguing specifically against eternity as such, but rather against the value of eternally remaining the same. 33 In doing so, he is moving toward an affirmation of the transitory character of continual creating as rooted in power.

${ }^{31}$ Soll argues on this basis that the importance of any proof of the eternal recurrence is less than central to Nietzsche's position, "all that is really required is a demonstration of the doctrine's possibility." (Ibid., p. 325.) Soll's arguments in this regard are unconvincing for, even if it is the psychological impact of this doctrine which is at stake, a proof would obviously lend it much greater import. Moreover, Soll ignores the question of how this could be proved--the question which is discussed below in the sections on the naming, thinking, and willing of the eternal recurrence.

12 .

$$
\begin{aligned}
& { }^{32} \mathrm{WM}, \S 1049, \text { p. } 683=\mathrm{WP}, \S 1049, \text { p. } 539 . \\
& { }^{33} \mathrm{WM}, \$ 577 \text {, p. } 392=\mathrm{WP}, \S 577, \text { p. } 310=\mathrm{NF}, \operatorname{VIII} / 2,9(26), \mathrm{p}
\end{aligned}
$$


Although the relationship between eternity and the moment is initially treated as an antithetical one, Nietzsche also argues that al1 eternity is necessary to affirm the moment. ${ }^{34}$ His argument develops in two directions. On the one hand, it is the moment which redeems and affirms all of existence; one proceeds from the moment outward to eternity. On the other hand, the argument also proceeds from the insufficiency of all things and selves inward toward the moment, the necessary condition of the moment's completeness being its affirmation by all eternity. Eternity is rejected only insofar as it remains unmediated by the moment of creative action.

While the moment is characterized by creativity, it is necessary to see the notion of the moment within the perspective of Nietzsche's statement that nothing exists for itself. One can say that the notion of a "true world" is put into question. In the search for a better world, or at least a more tolerable one, man continually creates new fictitious worlds. ${ }^{35}$ It is a short step then to understanding the "real" world as "the apparent world once again."36 The "once again"

${ }^{34} \mathrm{WM}, \S 1032, \mathrm{p} .675=\mathrm{WP}, \S 1032, \mathrm{pp} .532-33$. As Joan Stambaugh has pointed out, when the moment is thought to be "ein einmaliger $\mathrm{Zu}$ stand," a "nunc stans. . . zeitlose Ewigkeit," then the moment excludes al1 other moments. ("Das Gleiche in Nietzsche Gedanken der Ewigen Wiederkunft des Gleichen," Revue International de PhiZosophie, Vo1. 67, No. 1 [1964], p. 111.) Clearly Nietzsche is not referring here to an isolated moment, but to a dynamic one in the flow of time.

144.

$$
{ }^{35} \mathrm{WM}, \S 586, \text { p. } 407=\mathrm{WP}, \S 586, \text { p. } 321=\mathrm{NF}, \mathrm{VIII} / 3,14(168), \mathrm{p} \text {. }
$$

$$
36 \mathrm{WM}, \$ 566, \mathrm{p} .386=\mathrm{WP}, \$ 566, \mathrm{p} .305=\mathrm{NF}, \mathrm{VIII} / 2,11(50), \mathrm{p},
$$
266. 'Die 'wahre Welt', wie immer auch man sie bisher concipirt hat,-sie war immer die scheinbare Welt noch einmal." 
character of this creation points to a second way of understanding the eternal recurrence: what recurs again and again is the same act, the act of creating new worlds. Nothing exists for itself, but rather it must be continually created in the moment.

This corresponds to Nietzsche's description of truth in terms of an eternal, active creating which has its foundation in the will to power. 37 The process of truth is an eternal making, and one puts out of sight that which is false--just as one hides unused props and scenery behind the stage in a play. The eternal character of this process corresponds to the eternal creating discussed above. That out of which one creates, if one may interpolate from an earlier text, is the great and the small--that chaotic plurality which, as will be shown below, is fundamentally force. That which does the creating is the will to power.

In descriptions of the physical world, it is therefore inadequate to speak of regularity or conformity to a law as if one were dealing with a real law expressive of the nature of things themselves. Such formulations are only metaphorical. ${ }^{38}$ Laws, rather than referring to things in themselves, are themselves the results of creative acts. The Law of the Eternal Recurrence of the Same

In this section I shall show that the doctrine of the eternal recurrence of the same can be understood as a law--if law is taken in

$$
\begin{aligned}
& 37_{\mathrm{WM}}, \S 552, \text { p. } 377=\mathrm{WP}, \S 552, \text { p. } 298 . \\
& 38_{\mathrm{WM}} \$ 632, \text { p. } 426=\mathrm{WP}, \S 632, \text { p. } 336 .
\end{aligned}
$$


the Nietzschean sense. First, laws for Nietzsche will be shown to be the result of creative interpretations, not statements about things in themselves. Second, it will be shown that the basis of this interpretation is power--laws are creative expressions of the will to power. The eternal recurrence of the same is not based on an uncritical understanding of physical law. It is necessary to distinguish here between two different conceptions of law: (1) as descriptive of the way things in the world behave, thus applicable to things in themselves, and (2) law as a creative extension or exercise of the will to power. Although it appears to be presented as such in several places in Zarathustra and The Joyful Wisdom and in some of the discussions in the secondary literature, the doctrine of the eternal recurrence is clearly not meant to be a law in the first sense.

One finds in The Joyful Wisdom a clear rejection of any mechanistic view of the world. One reason for such a rejection is that a structure of explanation such as this, one which interprets the world in terms of a machine, tends to posit a goal or end. ${ }^{39}$ The same problem is considered elsewhere, and there it is argued that the mechanistic interpretation is worthless--and not in good taste--because it treats only what can be counted. ${ }^{40}$ In so doing, it is not only totally ignoring the worth of that which is under consideration, but it is also divesting existence of its ambiguous character, substituting one

$$
\begin{aligned}
& { }^{39} \mathrm{FW} \text {, III, } \$ 109, \text { p. } 126=\mathrm{JW}, \text { III, } \$ 109, \text { p. } 151 . \\
& 40_{\mathrm{FW}}, \mathrm{V}, \$ 373, \mathrm{p} .290=\mathrm{JW}, \mathrm{V}, \$ 373, \mathrm{p} .339 .
\end{aligned}
$$


interpretation for the multiplicity of possible perspectives.

When Nietzsche discusses the new "infinite" of the fearless ones, he argues that the world may contain infinite interpretations, especially in relation to time. ${ }^{41}$ The possibility of perceiving time differently is presented as a "hopeless curiosity," but this hopeless curiosity will transform itself into "the most horrible and most liberating of thoughts," the eternal recurrence of the same.

It seems, however, that this infinity of interpretations is such that it excludes some interpretations. Just as the world is not to be viewed mechanistically, so too it is not to be viewed as a living being. ${ }^{42}$ Nietzsche also rejects the position that the world eternally creates the new or that there are eternally enduring substances. ${ }^{43}$ In fact, much of his energy and writing was devoted to showing why some interpretations are untenable. If there is an infinity of interpretations, some are considered to be much better than others--and presumably the eternal recurrence of the same is meant to be the best. Rejecting the above interpretations, Nietzsche does recognize the existence of necessity 44 and chaos. Order, structure, form, beauty, wisdom and other aesthetic elements of humanness are absent from the world; there is necessity, but it is not such that it can be termed

$$
\begin{aligned}
& \quad 41_{\mathrm{FW}}, \mathrm{v}, \$ 374, \mathrm{p} .291=\mathrm{JW}, \mathrm{v}, \$ 374, \mathrm{pp} .340-41 . \\
& 42_{\mathrm{FW}} \text {, III, } \$ 109, \mathrm{p} .126=\mathrm{JW}, \mathrm{III}, \$ 109, \mathrm{p} .151 . \\
& 43_{I b i d ., \mathrm{p} .} 127=i b i d ., \mathrm{pp} .151-52 . \\
& \quad 44 \text { Even this necessity is an interpretation. Cf. WM, } \$ 552, \mathrm{p}, \\
& 376=\mathrm{WP}, \$ 552, \mathrm{p}, 297 .
\end{aligned}
$$


a law in nature itself. ${ }^{45}$ Given this, it is clearly impossible to maintain that the eternal recurrence of the same is to be interpreted as a physical law in the traditional sense of that term.

The problem is clarified somewhat if one considers the relation between 1 aw and power. Law was rejected because it involved in some way a reduction of the manifold character of existence, and an imputation of purpose in that to which it refers or of a subject that directs the movement of phenomena. 46 Events simply have a "thus and not otherwise" character, and the foundation for this necessity is power. "There is no law: every power draws its ultimate consequence at every moment. Calculability exists precisely because there is no middle term." 47 Thus it is power which is the foundation of the necessity which Nietzsche admits as legitimate, but it escapes treatment as law because it exists fully in the moment, because there is no subject directing the movement and on purpose toward which it is moving.

If every power draws its ultimate consequences at every moment, then it would appear that the eternal recurrence refers to power--since it apparently cannot refer to any structure (such as order, beauty, law, etc.) beyond or above power. At this point it is necessary to establish the relationship between the eternal recurrence and the will

$$
\begin{aligned}
& 45 \mathrm{FW}, \mathrm{III}, \$ 109, \mathrm{p} .127=\mathrm{JW}, \mathrm{III}, \$ 109, \mathrm{p} \cdot 152 . \\
& 46_{\mathrm{WM}} \$ 632, \text { p. } 426=\mathrm{WP}, \$ 632, \mathrm{p} .337 . \\
& 47_{\mathrm{WM}} \$ 634, \text { p. } 427=\mathrm{WP}, \$ 634, \mathrm{p} .337=\mathrm{NF}, \mathrm{VIII} / 3,14(79), \mathrm{p} .
\end{aligned}
$$
50. "Es giebt kein Gesetz: jede Macht zieht in jedem Augenblick ihre letzte Consequenz. Gerade, daß es kein mezzo termine giebt, darauf beruht die Berechenbarkeit." (The Kröner edition has "Anderskönnen" for "mezzo termine.") 
to power and force. The law of the eternal recurrence depends upon whether or not the 1 aw can be expressive of force. It cannot be expressive of force according to Nietzsche if this involves position a notion of a subject directing the force, if it implies a purpose, if it attempts to reach things in themselves, if it involves a reduction of the richness of existence, or if it covers up a real ambiguity. What we say about the relationship between the eternal recurrence and power cannot have the status of a law if it involves these conditions. The Relationship of the Eternal Recurrence and Power-Force

In this section, I sha11 outline the basic meaning of the terms "force" and "power" within Nietzsche's philosophy and show how two additional meanings of "that which recurs eternally" emerge from his idea of force: the eternal recurrence of a given combination of centers of force and the eternal recurrence of given levels of energy. In doing this, I shall also examine briefly Nietzsche's proof of the eternal recurrence as developed in his notebooks.

The remarks on the problem of force and power are to be found primarily in Nietzsche's notebooks. The consideration here will be based mainly on passages gathered together in the Wizl to Power.

First, force (Kraft) and power (Macht) are treated together because in general they are related to each other as outer to inner. Will to power is the inner organizing will of force, 48 force specified as seeking to increase itself.

$$
{ }^{48} \mathrm{WM}, \S 619, \mathrm{p} .421=\mathrm{WP}, \S 61 \S, \mathrm{pp} .332-33
$$


Second, the substratum of force is absolute space. In a passage to which I shall return below, Nietzsche discusses space and time.

I believe in absolute space as the substratum of force: the latter limits and forms. Time eternal. But space and time do not exist in themselves. $49^{\circ}$

This is not an argument for the absolute character of space, but rather a statement of belief in it, a laying bare of presuppositions. Perhaps the reasoning behind this is that, were space infinite, then force would be continually dispersing itself over this infinite space. So force must limit and form this absolute space which does not exist in itself. Third, the force which exists in this manner must be a finite quantum. The idea of infinite force is clearly rejected as a contradiction in terms, presumably because it is the very nature of thinking to impose some kind of limit; thus unlimited force is unthinkable. 50 It is for this reason that eternal novelty is impossible. Not only is there a finite amount of force, but there is also only a finite number of centers of force. 51 It is because of this that the "great dice game of existence" must repeat itself--if there is infinite time. Both force and space must be finite and time must be unending if the eternal recurrence is to be, not just possible, but necessary--and Nietzsche asks us to think the world in this manner. The eternal recurrence of

49 WM, $\$ 545$, pp. $370-71=W P, \$ 545$, p. 293. "Ich glaube an den absoluten Raum, als Substrat der Kraft: diese begrenzt und gestaltet. Die Zeit ewig. Aber an sich gibt es nicht Raum, nicht Zeit."

p. 168 .

$$
\begin{aligned}
& 50_{\mathrm{WM}}, \$ 1062, \mathrm{p} .693=\mathrm{WP}, \$ 1062, \mathrm{p} .547 . \\
& 51_{\mathrm{WM}}, \$ 1066, \text { p. } 696=\mathrm{WP}, \$ 1066, \text { p. } 549=\mathrm{NF}, \mathrm{VIII} / 3,14(188) \text {, }
\end{aligned}
$$


the same is the result of understanding existence as a dice game: a particular type of play with a finite number of pieces and limited space, but played on through eternity.

A number of arguments have been arised against this notion of the eternal recurrence, notably by Simme ${ }^{52}$ and Capek. ${ }^{53}$ Simel's argument is well summarized by Kaufmann:

Simmel has offered a very elegant refutation of Nietzsche's attempted proof of the eternal recurrence of the same events. Even if there were exceedingly few things in a finite space in an infinite time, they would not have to repeat the same configurations. Suppose there were three wheels of equal size, rotating on the same axis, one point marked on the circumference of each wheel, and these three points lined up in one straight line. If the second wheel rotated twice as fast as the first, and if the speed of the third wheel was $1 / \pi$ of the speed of the first, the initial line-up would never recur. 54

While Simmel's argument is valid in itself, it should be noted that there are two limitations to it. First, it is only an argument against the necessity of the eternal recurrence, not against its possibility. Second, it does interpret Nietzsche's doctrine of the eternal recurrence as referring to things in themselves. A more consistent interpretation of the doctrine of the eternal recurrence as a creative expression of the will to power allows one to maintain the doctrine of the eternal recurrence in a sense other than Simmel has interpreted it, since Simmel's argument is based on an understanding of eternal recurrence

${ }^{52}$ Georg Simme1, Schopenhauer und Nietzsche: Ein Vortragszyklus (Leipzig: Duncker und Humblot, 1907), pp. 250 f.

53 Milic Capek, "The Theory of the Eternal Recurrence in Modern Philosophy," Joumal of Philosophy, LVII, 9 (Apri1, 1960), 289-95.

${ }^{54}$ Kaufmann, Nietzsche, p. 327. 
as a physical law referring to things in themselves,

Capek's criticisms are significant in that they show that the eternal recurrence of the same can be shown to be necessary on the leve1 of the cosmos, "assuming, of course, that the universe is like a pack of cards." 55 Such an assumption, in Capek's view, is clearly inconsistent with the results of contemporary physics, which does not deal with a universe of things, but rather of events and dynamic quanta. Insofar as Nietzsche also seeks to deal with the universe in these terms, Capek's criticisms of the eternal recurrence appear to be quite applicable to Nietzsche's position, suggesting that Nietzsche's proof of the eternal recurrence is not consistent with his conception of the universe as composed of dynamic quanta of force. Further development of the Nietzschean idea of a quantum of force is necessary here in order to determine whether the eternal recurrence of the same quanta of force can be consistently maintained within Nietzsche's framework. For Nietzsche, a quantum of force is not to be conceived as an "unfree will."56 It simply implies that things are "thus and thus."57 Dynamic quanta remain, all of which are in relation to all the others. What one might call their "essence" is their relation to all other quanta, their "effect" upon them, 58 although such language is at best

\footnotetext{
${ }^{55}$ Capek, "Eternal Recurrence," p. 291.$$
{ }^{56} \mathrm{WM}, \S 552, \text { p. } 375=\mathrm{WP}, \S 552, \text { p. } 297 .
$$$$
{ }^{57} \mathrm{WM}, \$ 632, \mathrm{p} .426=\mathrm{WP}, \$ 632, \mathrm{pP} .336-37 \text {. }
$$$$
58 \text { WM, \$635, p. } 429=W P, \$ 635, \text { p. } 339=N F, \operatorname{VIII} / 3,14(79) \text {, }
$$

p. 51 .
} 
only metaphorical. These quanta are referred to as power-will (Machtwillen) and as the will to power. They are designated by the effects they produce. The eternal recurrence of the same is in this sense merely an expression of the tautological character of force present in its givenness as will to power, its being what it is and nothing more.

The absolute necessity of the same events occurring in the course of one world, as in all others, is in eternity not a determinism ruling events, merely the expression of the fact that the impossible is not possible... that a certain force cannot be other than this certain force; that it can react to a quantum of resisting force only according to the measure of its strength; event and necessary event is a tautology. 59

The tautological character of force, its being what it is in the moment and nothing more, when placed within absolute space and when force is seen as finite, serves as the basis of the eternal recurrence of the same if time is infinite. The eternal recurrence is not a law governing events, but rather an expression of the tautologous character of force. Thus the appropiateness of pathos, rather than becoming or effect, as the most elementary starting-point: ${ }^{60}$ pathos is the event of a multiplicity of centers of force being themselves by being in relation to a11 other centers of force.

$59 \mathrm{WM}, \$ 639$, p. $432=\mathrm{WP}, \$ 639$, p. $341=\mathrm{NF}, \mathrm{VIII} / 2,10(138)$, pp. 201-02. ". . . die absolute Necessität des gleichen Geschehens in einem Weltlauf wie in allen übrigen in Ewigkeit, nicht ein Determinismus über dem Geschehen, sondern bloß der Ausdruck dessen, daß das Unmögliche nicht mögliche ist . . . daß eine bestimmte Kraft eben nichts anderes sein kann als eben diese bestimmte Kraft; daß sie sich an einem Quantum Kraft-Widerstand nicht anders ausläßt, als ihrer Stärke gemäß ist-Geschehen und Nothwendig-Geschehen ist eine Toutologie."

p. 51 .

$$
60_{\mathrm{Wm}}, \$ 635, \text { p. } 429=\mathrm{WP}, \$ 635, \text { p. } 339=\mathrm{NF}, \operatorname{VIII} / 3,14(79) \text {, }
$$


Yet one must be careful about how this totality is conceptualized. The totality does not remain the same; rather, existence is first and foremost an event, and it is implied that it is developmental insofar as the energy rises and falls.

Regarded mechanistically, the energy of the totality of becoming remains constant; regarded economically, it rises to a high point and sinks down again in an eternal circle. This "will to power" expresses itself in the interpretation, in the manner in which force is used up; transformation of energy into life, and "life at its highest potency," thus appears as the goal. The same quantum of energy means different things at different stages of evolution. 61

Here then the notion of the eternal recurrence is presented with a slightly different emphasis: the rising and falling of the energy of the totality in an eternal circle, in which what continually returns is the same level of energy. Such an interpretation is not subject to the criticisms that Capek has levelled against the notion of the eternal recurrence. The will to power is the principle of motion in this unending circle of expansion and contraction, It is an interpreter in the original sense of the word: an agent, in this case the agent of power. This relationship will be explored in more detail below.

Two preliminary meanings of the eternal recurrence have thus

$$
61_{\mathrm{WM}}, \$ 639, \text { p. } 431=\mathrm{WP}, \$ 639, \mathrm{p} .340=\mathrm{NF}, \mathrm{VIII} / 2,10(138) \text {, }
$$

p. 201. "--mechanisch betrachtet, bleibt die Energie des Gesammtwerdens constant; ökonomisch betrachtet, steigt sie bis zu einem Höhepunkt und sinkt von ihm wieder herab in einem ewigen Kreislauf; dieser 'Wille zur Macht' drückt sich in der Ausdeutung, in der Art des Kraftverbrauchs aus--Verwandlung der Energie in Leben und Leben in höchster Potenz erscheint demnach als Ziel, Dasselbe Quantum Energie bedeutet auf den verschiedenen Stufen der Entwicklung Verschiedenes . . ." 
far presented themselves in this section. In the first, the eternal recurrence is merely an expression of the tautological character of power given the following conditions: limited space, a finite number of centers of force, unending time. That which returns then is the given combination of centers of force. In the second instance, the eternal recurrence expresses the rising and sinking of the energy of the totality of becoming, considered economically (rather than mechanistically), in an eternal circulation. In this case, that which returns is the same level of energy as interpreted by the will to power. 62 While it may be possible to show that these are but two different ways of stating the same general condition, it should be noted that there are important differences, both in regard to the reasons given for them and in relation to their determinateness. The first formulation, with its emphasis on centers of force, is rather more specific than the second, which is concerned with the level of energy. That the will to power interprets such energy and consequently defines centers of force is indeed true for Nietzsche, but this formulation does not state that it is these centers of force which return.

Before considering in more detail the ways in which force and power are interpreted--through naming, willing, acting and the artistic act--it is necessary to consider briefly the primacy of power, since this provides the basis for the subsequent discussion of knowing the

62 These are the third and fourth possible meanings of "that which returns eternally the same." The first two were (1) al1 aspects of one's personal existence, including the unspeakably great and small, and (2) the act of continually creating new worlds. 
eternal recurrence.

The Primacy of Power-Force

The primacy of power and force, discussed above in relation to the universe as a whole, is also found in the human world. The concept which provides the mediating link between the cosmological analysis and the analysis of human behavior is that of the event. As used above, event was something which occurred in the world. All events are necessary; event and necessary event is a tautology. Events are determinations of force, in respect to both degree and relation. 63 But the determination of force is also a function of sensation. 64 Both the event and sensation are determinations of force. Sensation is a specific kind of event, retaining the general structure of interpreting power. It is on this foundation that knowing stands--and that will be of upmost importance when considering the possibility of knowing the eternal recurrence.

The event then exists not only in the cosmological sense, but also as the foundation of the human world and of knowing. Insofar as the event is rooted in force, then the foundation of both orders--the reference to two orders here is not meant to imply that there are necessarily two distinct orders existing in themselves--is the structure of the event, its determination of force, which is the will to power. This presents a fifth possible meaning of that which returns

\footnotetext{
$63_{\mathrm{WM}} \$ 552$, p. $378=\mathrm{WP}, \$ 552$, p. 297.

${ }^{64} \mathrm{WM}, \S 563$, pp. $384-85=\mathrm{WP}, \$ 563$, p. 304 ; WM, $\$ 500, \mathrm{p} \cdot 345=$ WP, $\$ 500$, p. 273.
} 
eternally the same: the event as a determination of force. The Meaning of "the Some"

At this point in the analysis, before considering how the eternal recurrence is willed, it is necessary to inquire in more depth into the meaning of "the same" in the doctrine of the eternal recurrence of the same in order to show the foundation of sameness in power. On the basis of these considerations, I shall show that there are two additional possible meanings of "that which recurs eternally": the same apparent world, in either of two senses as (1) the specific content of such a world, and (2) its character as being an appearance, i.e, its falsity. These constitute the sixth and seventh possible meanings of that which eternally recurs the same. In addition to this, it will be shown that sameness is not given in the world, but rather that we create sameness. It is an expression of our power over the world, In this sense, the strongest will to power demands the greatest creation of sameness--this is the creation of the eternal recurrence of the same. Finally, the following section establishes the framework within which the modes of affirming the eternal recurrence--especially naming, thinking, and willing as expressions of the will to power--can be considered.

One can begin such an investigation by recognizing that the general character of the world is chaos. ${ }^{65}$ If this is the case, then a sixth possible meaning of that which eternally recurs the same is

$$
{ }^{65} \mathrm{FW}, \text { III, } \$ 109, \text { p. } 127=\mathrm{JW}, \text { III, } \$ 109, \text { p. } 152 \text {. }
$$


chaos. In his description of "the most dangerous point of view," Nietzsche sets the stage for such an interpretation. "What I now do, or neglect to do, is as important for alz that is to come, as the greatest event of the past: in this immense perspective of effects all actions are equally great and smal1."66 "ij, : What are "the same" are a11 actions--they are equally great and small. If "great and sma11" is taken to indicate an undifferentiated plurality, then the sameness in which they share here is quite close to chaos. What seems to happen in this most dangerous of perspectives is that all measure disappears, thus allowing all things to be equally great and small, significant and insiginificant. Chaos is just such an absence of measure. In this case, the "same" which would recur eternally would be chaos, the realization in the end that there is no final measure in terms of which the manifold of existence may be judged.

Yet such an explanation is insufficient as it stands, for the notion of "the same" must be shown to be consonant with Nietzsche's demand for a total affirmation of life in a creative manner. Sameness must be creatively affirmed, not simply given.

A first clue to the solution of this problem is found in Nietzsche's analysis of the function of logic. Just as the world is chaos, so one originally encounters a chaos of ideas. ${ }^{67}$ The function

$66 \mathrm{FW}$, III, $\$ 233, \mathrm{p}, 170=\mathrm{JW}, \mathrm{III}, \$ 233, \mathrm{p}, 202$. "Was ich jetzt tue oder lasse, ist für alles Kommende so wichtig als das größte Ereignis der Vergangenheit: in dieser ungeheuren Perspektive der Wirkung sind alle Handlungen gleich groß und klein."

$$
67_{\mathrm{WM}}, \S 508, \mathrm{p} .348=\mathrm{WP}, \S 508, \text { p, } 276 .
$$


of logic is to impose order upon this chaos by seeing things as the same. On the natural level, there exists a movement toward "making the same" what is appropiated--the limits of this being usefulness and harmfulness. On the human level, the same movement of making--positing and seeing--things as equal exists, and it is this which is the foundation of $\operatorname{logic} .68$

The background out of which logic arises is then this original chaos--again, existence as a form of play, but this time a lawless play, hardly dserving of the term. 69 Logic uses this chaos as the raw stuff out of which it seeks to establish identities by creating fictitious worlds. Only after this fundamental falsificiation of events is assumed does logic become possible. 70

There is a distinction here between identity and sameness, but Nietzsche hardly takes pains to make clear what it is. It is important in understanding the eternal recurrence to know whether Nietzsche means that the same, the identical, or the self-identical eternally recurs. One can begin by suggesting that identity has its foundation in sameness, the appearance that things are the same. 71 It is this, the creation of sameness, which allows us to comprehend the world, even if the world which we comprehend is a falsification. However, the

$68_{\mathrm{WM}}, \$ 510$, p. $349=\mathrm{WP}, \$ 510$, p. 276 .

${ }^{69}$ We do, however, use the word in this sense when we speak, for example, of "the play of reflections on the water."

$$
\begin{aligned}
& 70_{W M}, \$ 512, \text { pp. } 349-50=W P, \$ 512, \text { p. } 277 . \\
& 71_{W M} \$ 520, \text { pp. } 355-56=W P, \$ 520, \text { p. } 281 .
\end{aligned}
$$


appearance of "same things" is open to question in a number of ways.

First, the foundation of these "same things" is located in our belief in things--which is the precondition of our belief in logic. 72 But Nietzsche himself rejects such a belief 73 insofar as it claims to refer to anything but an apparent world.

Second, the notion is criticized from the standpoint of "sameness." Sameness is not simply posited, it is made. The process of making things the same (ein Gleich-machen) comes before that of positing sameness (ein Gleichsetzen). ${ }^{74}$ If the foundations of logic are seen within this context, then logic can be interpreted as a creative act. Third, Nietzsche criticizes the notion of sameness in terms of its origins. Logic grows out of the herd instinct, and is used to achieve mutual agreement and domination. The positing of sameness in various events presupposes similar or same souls (gleiche Seele). ${ }^{75}$ The effects of this drive toward sameness are powerful enough that Nietzsche feels justified in saying that this changes the very way that we sense things. The compulsion to create a world of identical cases reshapes our sense of reality.

This same compulsion exists in the sense activities which support reason--by simplification, coarsening, emphasizing, and elaborating, upon which all "recognition," all ability to make oneself intelligible rests. Our needs have made our senses so precise that the

$$
\begin{aligned}
& 72 \mathrm{WM}, \$ 516, \text { p. } 353=\mathrm{WP}, \$ 516, \text { p. } 279=\mathrm{NF}, \mathrm{VIII} / 2,9(97), \text { p. } 53 . \\
& { }^{73} \text { Ibid.; WM, } \$ 553, \text { p. } 379=W P, \$ 553, \text { p. } 300 . \\
& 74 \mathrm{WM}, \$ 501, \text { p. } 345=\mathrm{WP}, \$ 501, \mathrm{pp} .273-74 \text {. } \\
& 75 \mathrm{WM}, \$ 509 \text {, p. } 349=\mathrm{WP}, \$ 509, \text { p. } 276 .
\end{aligned}
$$


"same apparent world" always reappears and thus has acquired the semblance of reality. 76

That "the same apparent world always reappears" would apparently be rooted in these needs: to construct concepts, species, forms, 1aws, purposes, etc., which presumably are in turn rooted in more fundamental needs to live and to increase power. The foundation of sameness is in the same sensations, ${ }^{77}$ but such sensations themselves are a function of something else. At this point a seventh possible meaning of the eternal recurrence appears: it is the same apparent world that recurs eternally. The emphasis could be placed here on either the content of that world or its formal characteristic as being "apparent." In the latter case, whatever world occurs would be a falsification, in which case, it is the falsity of one's world which eternally recurs. Thus we encounter here the eternal recurrence of the same in two senses: the same characteristic of falseness keeps recurring, and sameness is itself this process of falsification.

In attempting to discover what these needs for the recurrence of the same apparent world are, we uncover several levels. The Sichselbst-Gleiche is necessary for knowing. ${ }^{78}$ The construction of

$76 \mathrm{WM}, \$ 521, \mathrm{p} .357=\mathrm{WP}, \$ 521, \mathrm{p} .282=\mathrm{NF}, \mathrm{VIII} / 2,9(144), \mathrm{p}$. 82. ". . diese selbe Nöthigung besteht in der Sinnen-Aktivität, welche der Verstand unterstützt,--diese Vereinfachen, Vergröbern, Unterstreichen und Ausdichten, auf dem alles 'Wiedererkennen,' alles Sichverständlich-machen-können beruht. Unsre Bedürfnisse haben unsre Sinne so präcisirt, daß die 'gleiche Erscheinungswelt' immer wieder kehrt und dadurch den Anschein der Wirklichkeit bekommen hat."

$$
\begin{aligned}
& 77_{\mathrm{WM}} \$ 532, \mathrm{p} .366=\mathrm{WP}, \$ 532, \text { p. } 289 . \\
& 78_{W M} \$ 574, \text { p. } 391=W P, \$ 574, \text { p. } 309 .
\end{aligned}
$$


identical cases, of the appearance of sameness, is necessary for thought. 79 It is this, the construction of identical cases, which is the foundation of reality. "The 'reality' [of the phenomenal world] lies in the continual recurrence of same, familiar, related things in their logicized character, in the belief that here we are able to reckon and calculate." 80 Furthermore, the foundation of life itself is a belief in regular and recurring things. ${ }^{81}$ With this as the premise of life, the more powerful life is characterized by a wider and more knowable world. The most powerful life demands the most knowable world in which in turn the most recurring things are demanded--thus the demand for the eternal recurrence of the same arises out of an increase in power. In this sense, the foundation of the creation of sameness is located in the fact that it is a necessary condition of the possibility of life.

Moreover, sameness is a necessary condition of life, and the creation of sameness involves the very idea of the eternal recurrence. Insofar as creative life necessarily involves the creation of sameness, it simultaneously creates the necessity of the eternal recurrence. By presenting sameness as a condition of life, Nietzsche moves toward p. 216 .

$$
{ }^{79} \mathrm{WM}, \S 544, \text { p. } 370=\mathrm{WP}, \S 544, \text { p. } 293=\mathrm{NF}, \operatorname{VIII} / 2,10(159),
$$

$$
80_{\mathrm{WM}}, \S 569, \mathrm{p} .388=\mathrm{WP}, \$ 569, \mathrm{p} .307=\mathrm{NF}, \mathrm{VIII} / 2,9(106),
$$
pp. 59-60. "Die 'Realität' liegt in dem beständigen Wiederkommen gleicher, bekannter, verwandter Dinge, in ihrem logisirten Charakter, im Glauben, daß wir hier rechnen, berechnen können."

$$
81_{W M}, \S 552, \text { p. } 377=W P, \S 552, \text { p. } 278 .
$$


establishing a transcendental argument for the eternal recurrence of the same.

Finally, it has been shown that Nietzsche argues against attributing sameness to any effective subject, and that he also argues against positing a notion in which it resides. In its fullness, the notion of sameness refers neither to subject nor to object, but to event. 82 Now it has been shown above that the foundation of the event is power, and its organizing principle the will to power. Then sameness refers to the tautological character of power which is present always and fully and necessarily in the moment. The foundation of sameness is thus not in things or subjects, but rather in events. The creation of sameness is simultaneously the creating of the eternal recurrence of the same. The foundation of the creation of sameness is located, on the one hand, in the tautological character of power, and, on the other hand, in the will to power. In this sense, an eighth possible interpretation of that which recurs eternal1y the same reveals itse1f: force recurs eternally and is the foundation of all sameness.

There remains this problem: can the eternal recurrence of the same be affirmed (whether this involves willing, thinking, or some other means) without introducing difference by the one who is doing the affirming? If difference were introduced, this would seem to result in a different situation recurring--or occurring--and consequently destroying the sameness of the eternal recurrence. In order to avoid this, the affirmation of sameness must contain within it its 
own ground in terms of sameness. The act of affirming the same must be a necessary consequence of sameness itself if we are to avoid introducing difference into the affirmation itself.

Now this is in fact the case for Nietzsche insofar as sameness is always an expression of power: when considered with a "cosmological" perspective, sameness is expressive of the tautological character of power; when considered from the perspective of the individual, sameness is the will to power affirming the necessary character of events which exist as qufalta of power. Sameness, as the expression of power, involves the affirmation of itself on both the cosmological and the individual levels.

The primacy of power, which was established in the previous section, is then reaffirmed by the notion of sameness. It now remains. to be shown that this is consistent with the various modes of affirmation of the eternal recurrence.

The Thinking and Naming of the Eternal Recurrence

The eternal recurrence does not refer as a doctrine to things in themselves, nor can it be taken as a law descriptive of a mechanistic universe. If it were, it would indeed be disproved by the criticisms of Simmel and Capek discussed above; but it is not. The eternal recurrence of the same is an expression of power which must be affirmed in appropriate ways. If we are to understand the fundamental meaning of the eternal recurrence, we must consider the ways in which Nietzsche meant it to be affirmed. The notion is clearly not a statement about a mechanistic world. Three of the modes of such creative affirmation are naming, thinking, and willing. 
The naming and thinking of the eternal recurrence stand as two ways, distinguishable but not separate, in which it is not simply affirmed but created. To think and to name the eternal recurrence are to create it. Let us examine the basis for such a statement, and then explore some of its consequences.

As the comments on Nietzsche's treatment of logic have indicated, language is an expression of the will to power. Poetry, for example, is a form of power used to constrain the gods. 83 Naming is fundamental to this process, for naming suffices in the end to create new things. 84 The demand to create anew can be seen in some senses as a demand for the purification of language and feeling. 85 This applies not only to the creation of language, but also to its interpretation. 86 The creative power of the individual is thus located in his speaking--both naming and interpreting.

Treating naming and interpreting as creative acts is consonant with Nietzsche's view of knowledge and its experimental character. Both life and knowledge are experiments, and the fundamental question is the question of the degree to which truth can be embodied. 87 Although Nietzsche will maintain elsewhere that this is actually an experiment

$$
\begin{aligned}
& 83_{\mathrm{FW}}, \mathrm{II}, \S 84, \mathrm{pp} \cdot 98-102=\mathrm{JW}, \mathrm{II}, \S 84, \mathrm{pp} \cdot 116-20 \text {. } \\
& 84 \mathrm{FW}, \text { II, } \$ 58, \text { p. } 81=\mathrm{JW}, \mathrm{II}, \S 58, \text { p. } 97 . \\
& 8^{8 W} \mathrm{FW} \text { IV, } \$ 335, \text { p. } 224=\mathrm{JW}, \mathrm{IV}, \S 335, \text { p. } 262 . \\
& 86_{\mathrm{WM}}, \S 767, \mathrm{p} .512=\mathrm{WP}, \S 767, \mathrm{p} .403 . \\
& 87 \mathrm{FW}, \text { III, } \$ 110, \text { p. } 130=\mathrm{JW}, \text { III, } \$ 110, \text { p. } 156 .
\end{aligned}
$$


of the thinker, ${ }^{88}$ the fundamental ground of this experimenting, as has been shown in Chapter Five, cannot be the self, but rather must be power. Even the conflict between truth and error is a conflict between two powers. Life is an experiment, but we are not cast solely in the role of the experimenters, but rather are also part of the experiment itself. The degree to which we are experimenters depends upon the degree to which we manifest the will to power; the weaker we are, the more we become the object of the experiment. 89

Naming is also given as the basis of $1 \mathrm{aw}$, and this is again directly related to power. ${ }^{90}$ Naming by the powerful is the basis of any law, and if the eternal recurrence of the same is taken in any sense as expressive of a law, it must be seen within this context. In this sense, the law of the eternal recurrence of the same can be seen to be expressive of a creative act rooted in power. ${ }^{91}$

$88 \mathrm{FW}$, IV, $\$ 324$, p. $213=\mathrm{JW}$, IV, $\$ 324$, p. 250 .

${ }^{89}$ This is a matter of degree and depends in part on the notion of the self which was discussed in Chapter Five. Presuming that the experimenter is the active one, then the experimenter is the one who reaches out for power, while the passive one--the object of the experiment--is the one who (or which) is hindered from moving forward. (This interpretation is based on the notions of "active" and "passive" in WM, \$657, p. 439 =WP, \$657, pp. 346-47.) Again it should be noted that this is a matter of degree, not an absolute dichotomy.

$$
90_{\mathrm{WM}} \$ 513, \text { p. } 350=\mathrm{WP}, \$ 513, \text { p. } 277 .
$$

91 Jaspers indicates this in his treatment of the eternal recurrence and shows how even the mechanical view of the world involves transforming a "lawless play" into a consistent one. Cf. his Nietzsche: An Introduction to the Understnading of his Philosophical Activity, p. 355 . 
We can only comprehend a world which we create. 92 The foundation of this creation is power. Knowledge itself is a too1 of the will to power, and it increases proportionately with every increase in power. 93 As already noted, this is a process which involves creating a deception. Thus there is in us a power (Macht, not Vermogen) that is the basis of knowledge. 94 Knowledge is the result of power creating and shaping its world. Insofar as we can say that we know the eternal recurrence, we again do so as an expression of a creative power.

Not only does the structure of naming, thinking and knowing reveal to us its foundation in power--and its consequent tautological character as power affirming itself--but we find again that this involves also the affirmation of sameness. We have already shown that behind the principle of identity is the "appearance" that things are the same. 95 We construct sameness before we think it. 96 Insofar as we can be said to know the eternal recurrence of the same, it would appear that we are fully exercising knowing itself: the fullness of knowing demands sameness, but it also demands the creation of sameness. Thus the continual creative recurrence of the same arises necessarily

\footnotetext{
$92 \mathrm{WM}, \$ 495$, p. $433=\mathrm{WP}, \S 495$, p. 272.$$
93 \mathrm{WM}, \S 480, \text { p. } 336=\mathrm{WP}, \S 480, \mathrm{p} .266=\mathrm{NF}, \operatorname{VIII} / 3,14(122) \text {, }
$$
p. 94 . p. 46 .$$
{ }^{94} \mathrm{WM}, \S 517, \text { p. } 354=\mathrm{WP}, \S 517, \text { p. } 280=\mathrm{NF}, \operatorname{VIII} / 2,9(89) \text {, }
$$$$
{ }^{95} \mathrm{WM}, \S \S 520-21, \text { pp. } 355-58=\mathrm{WP}, \S \S 520-21, \mathrm{pp} \cdot 281-83 .
$$$$
96 \mathrm{WM}, \$ 544, \mathrm{p} .370=\mathrm{WP}, \$ 544, \mathrm{pp} \cdot 292-93=\mathrm{NF}, \mathrm{VIII} / 2,10(159) \text {, }
$$
p. 216 .
} 
as the basic presupposition--the foundation--of knowing as the creation of sameness.

Before this consideration of knowing the eternal recurrence can be complete, it is necessary to consider the relative impotence of such knowing as it is confined to the strictly intellectual level, lest one think that the eternal recurrence is created merely through an isolated act of thinking. Even as early as The Birth of Tragedy Nietzsche was conscious of the problem of the impotence of language and thought divorced from feeling and will--commenting, for example, on the inadequacy of language in regard to music. 97 Zarathustra speaks of the impotence of words--of the fool's words which, even if they were right, were nevertheless wrong. 98 What is necessary is to go to that which is behind naming, thinking and knowing: willing. It is necessary to will to make all things thinkable. 99 In this sense, "all meaning is will to power."100 The thinking of the eternal recurrence can be reduced to something more fundamental: the willing of it. The Willing of the Eternal Recurrence Through Power

In the previous discussions of the nature of the will and of the will to power, it was established that all of existence was to be

\section{$97_{\mathrm{GT}}, \mathrm{VI} ; \mathrm{III} / 1, \mathrm{p} \cdot 47=\mathrm{BT}, \mathrm{VI}, \mathrm{p} \cdot 55$} $98_{\mathrm{Z}}, \mathrm{III}$, "Vom Vorübergehen;" VI/1, p. $221=\mathrm{Z}$, III, "On Apos-
tates," p. 178.

99 Z, II, "Von der Selbst-Ueberwindung;" VI/1, p. $142=\mathrm{Z}$, II, "On Se1f-Overcoming," p. 113. zur Macht..."

$100_{\mathrm{WM}} \$ 590, \mathrm{p} .410=\mathrm{WP}, \$ 590, \mathrm{p} \cdot 323$. "Aller Sinn ist Wille 
understood ultimately in terms of will to power and that the will to power was basically one will which took on, or was specified, in the many different centers of force in the world. Willing, to express it in language not quite suitable to it, must always have an object (a something which is willed), and the basic nature of that "something" is power.

The act of willing is then expressive of force or power bringing itself into focus and seeking to extend its boundaries of influence. Will as a free act of an independent individual gives way to the will to power, which is the force which is at work within individuals. This leads finally to an identification of force and will in the notion of the will to power, which one might express in un-Nietzschean terms as force becoming conscious of itself, seeking to increase itself. Wi11, emerging as the organizing principle of force, leads to the self-grounding character of the will to power. While justification may be needed for willing anything but power, willing power is selfjustifying in that willing is power and what is thus willed is itself. When one asks who interprets an event, the final answer one receives is that the interpreting itself, which is will to power, does the interpreting. 101 The same answer would apply to willing. Who wills power? The will to power wills itself--and in so doing creates another meaning for the eternal recurrence of the same. What recurs eternally the same is the structure of all events as manifestations or instances of the will to power and nothing more. This is the ninth 
and final possible meaning of the eternal recurrence of the same.

There follows from this a specific kind of primacy which is given to "praxis" in Nietzsche's philosophy. Referring to the fearless ones as sensualists and representatives of the present and future in philosophy according to praxis rather than theoretica11y, $102 \mathrm{Nie}-$ tzsche points toward the direction philosophy was supposed to take: it should become a concrete activity, rather than a theoretical one divorced from life and power ${ }^{103}$ But even this activity appears, in the end, to be the will to power as thinking and interpreting; to phi1osophize about the will to power is at the same time to be will to power.

Conclusion: the Meaning of the Eternal Recurrence of the Same

The interdependence among sameness, the plurality of events which include the unspeakably large and small, force, event, interpretation, thinking and naming, and will has been shown by uncovering their common foundation in force organizing itself as will to power. The idea overarching these interpenetrating activities or events is the eternal recurrence of the same. It has been shown that the idea of the eternal recurrence of the same arises out of this framework in severa1 ways.

In response to the question of what it is that recurs eternally

$$
{ }^{\mathrm{IO}} \mathrm{FW}, \mathrm{V}, \$ 372, \mathrm{p} .288=\mathrm{JW}, \mathrm{V}, \$ 372, \mathrm{p} .336 \text {. }
$$

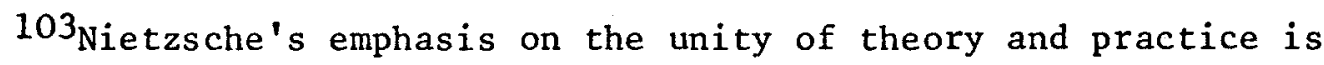
indicated, for example, in WM, \$423, pp. $287 \mathrm{ff}$. = WP, \$423, pp. 227 $\mathrm{FF} .=\mathrm{NF}, \mathrm{VIII} / 2,14(142)$, pp. $117 \mathrm{ff} . ; \mathrm{WM}, \$ 458, \mathrm{pp} .318 \mathrm{f} .=\mathrm{WP}$, $\$ 458$, p. $251=\mathrm{NF}, \mathrm{VIII} / 3,14(107), \mathrm{pp} .77-78$. 
the same, there are a number of possible answers: (1) all aspects of one's existence, including the unspeakably great and smal1; (2) the act of continually creating new worlds; (3) all given combinations of centers of force as in the dice game of existence; (4) the periodic rising and sinking of the level of the energy of existence economically considered; (5) the event as such, with the realization that all of existence has in itself the character of an event and nothing more; (6) chaos, whether in existence itself or in our ideas; (7) the same apparent world, whether in terms of its specific content as such or in respect to its being an appearance, i.e. its falsity; (8) power or force, leading to the insight that beneath all appearance there is only force or power; (9) the will to power, which leads to the rea1ization that the world is will to power and nothing more. In addition to this it has been shown that the creation of sameness is the necessary result of a number of our activities: (1) living itself demands the creation of sameness; (2) the activity of sensation involves making things the same; (3) thinking logically continues this process; (4) naming makes things the same; (5) thinking, (6) willing, and (7) willing power all involve creating sameness. These meanings are not contradictory, but rather are quite complementary, being descriptive of different aspects of the same phenomenon.

Moreover, these meanings help explain why the eternal recurrence of the same is the most horrible and the most liberating of thoughts. Its horribleness is to be found in the fact that it undercuts all previous concepts of the world. The experience of existence as a bare plurality, chaos, event, force, and appearance are constitutive of 
this horribleness; they are all aspects of the nihilist's experience of meaninglessness. Yet, once the shock of this realization is overcome, one begins to discover a certain kind of orderliness, the foundation of which is to be located in the will to power. Thus the many apparent worlds have something in common: their created apparentness. The chaos of events and ideas reveals itself to be of one fabric: force. These appearances in turn prove themselves to have a common structure: they are all manifestations of force organizing and increasing itself, will to power. A common element in the many ways in which the will to power organizes force is this: the creation of sameness. The will to power as the will to life creates sameness in many ways: through sensation, logic, naming, thinking, and willing. Insight into the nature of these activities yields the realization of the eternal recurrence of the same, which is in the end equivalent to the realization that the world is will to power and nothing more. What was called the tautological character of power is fundamentally this same thing: there is only the will to power, and it exists fully in the moment as an event, drawing its full consequences in each and every moment.

This means that the world simply happens; it is neither being nor becoming, but simply an on-going event. There is no justification for measuring one moment in terms of another moment, for al1 moments are of equal value; they all simply happen. Granting this, one begins to see the way in which this is the most liberating of thoughts: the absence of measure allows each moment to happen in its fullness. Precisely this is the overcoming of time, for time was the 
ultimate measure of all events. The "it was" had become the unchangeable measure of the present and the future. In willing the eternal recurrence, one now affirms all moments, including the past. Being had become the measure of becoming, sentencing it to insignificance by comparison. Now each moment is its own measure, not to be judged in terms of an absolute. The Christian conception of time had measured man in relation to eternity, putting a false weight on the individual's actions, a false measure. The eternal recurrence insures that nothing is measured in terms of a final goal, an eternity. The polytheistic view of time presented unlimited possibilities. The creation of the eternal recurrence prevents man's actions from being reduced to insignificance in the face of this infinity--they are to recur over and over again eternally. It now remains to explore the relationship between time and the eternal recurrence of the same.

C. Time and the Eternal Recurrence of the Same

Let us review our progress so far. The problem of time has four major aspects for Nietzsche: (1) the "it was," which paralyzes the will; (2) the tension between being and becoming; (3) the need to overcome traditional concepts of time; and (4) the demand for a creative affirmation of time. The doctrine of the eternal recurrence of the same offers a solution to these problems. The way in which it does so for the first three aspects of the problem has been indicated at the end of the preceding section. I shall now expand on this position, showing that time as the measure of appearances is overcome through the willing of the eternal recurrence, through the will to power. The 
result of this creative wiling is a new experience of time. This interpretation lays the foundation for the final section, in which the unity of the will to power and the eternal recurrence will be shown to reside in Nietzsche's vision of existence as creative play. The Nature of Time

We have already considered Zarathustra's exhortation to praise all impermanence, and the general primacy of becoming (more precisely, of the happening of the will to power) is evident at this point. It is within this context that the rejection of timelessness is to be understood.

'Timelessness' is to be rejected. At any precise moment of a force, the absolute conditionality of a new distribution of all its forces is given: it cannot stand still. 'Change' belongs to the essence, therefore also temporality: with this, however, the necessity of change has only been once more posited conceptually. 104

This passage is significant not only in that it shows the necessity of temporality, but also in that it shows this necessity to be only "conceptual." When Nietzsche writes elsewhere during the same year about this problem, he acknowledges that changes are only appearance. 105

But time is not an appearance; it is the measure of appearance, and it is for this reason that it must be overcome. In Zarathustra, it is madness which preaches that the law of time demands

$104 \mathrm{WM}, \$ 1064$, p. $694=$ WP, \$1064, p. 547. "'Zeitlos' abzuweisen. In einem bestimmten Augenblick der Kraft ist die absolute Bedingtheit einer neuen Verteilung aller ihrer Kräfte gegeben: sie kann nicht stillstehn. 'Veränderung' gehört ins Wesen hinein, also auch die Zeitlichkeit: womit aber nur die Notwendigkeit der Veränderung noch einmal begrifflich gesetzt wird."

$$
105_{\mathrm{WM},} \S 545, \mathrm{p} .371=\mathrm{WP}, \S 545, \mathrm{p} .293 .
$$


that it must devour its own children. 106 The passage which should be juxtaposed to this is in The Will to Power, where Nietzsche indicates that eternity must be given to everything in order to save it fully. 107 When eternity is given to everything, then nothing is measured in terms of anything else. Consequently, everything becomes the same in that it is no longer measured in relation to anything else: it is meaningless to say that something is different from something else without a common denominator, a basic measure. Difference, insofar as that depends upon measure of one thing in terms of another, is overcome. In this sense, the eternity of time demands that everything be regarded as self-identical, which results in no final state. Each moment remains, but not as a measure of any other.

The notion of time is further connected with the imposition of sameness insofar as knowledge of time and motion is dependent upon the need to believe in something at rest. ${ }^{108}$ This is in part attributed to the fact that we think only in the form of language. 109 Part of the problem of time is rooted specifically in the nature of language, which transforms events into things, dynamic processes into eternal truths. 110 The demand for sameness is at the root of logical thinking

106Z, II, "Von der Erlösung;" VI/1, p. $176=\mathrm{Z}$, II, "On Redemption," p. 140 . p. 285 .

$107 \mathrm{WM}, \S 1065, \mathrm{p} \cdot 694=\mathrm{WP}, \S 1065, \mathrm{p} \cdot 548=\mathrm{NF}, \mathrm{VIII} / 2,11(94)$,

$$
\begin{aligned}
& { }^{108} \mathrm{WM}, \S 520, \text { p. } 355=\mathrm{WP}, \S 520, \mathrm{p} \cdot 281 . \\
& { }^{109} \mathrm{Wm}, \S 522, \text { p. } 358=\mathrm{WP}, \S 522, \mathrm{p} \cdot 283 . \\
& { }^{110} \mathrm{Cf} \text {. Fink, Nietzsches PhiZosophie, p. } 87 .
\end{aligned}
$$


and leads to an eternal stasis if there is not something to overcome this.

The foundation of logic in power has already been noted. The solution to the problem of thinking time is to be found not simply in a new conceptualization of the problem--Nietzsche has indicated the insufficiency of this solution--but in changing the foundation of sensation itself. The foundation of sensation is pleasure, and the basis of pleasure is power, which in the case of intoxication involves an altered sensation of space and time. ${ }^{111}$ Time is to be overcome not simply on a conceptual leve1, but rather it must be overcome fundamentally on the level of sensation, and the basis of such an overcoming is power.

Time as the measure of appearance is then overcome in the will to power, and the consequence of this overcoming is the eternal recurrence of the same as the equality of appearance. The great and the small are seen as equal.112 It is this equality of appearance which allows the primacy of the moment, for everything to be a dance of the gods. 113 It is at this point that appearance exists as sufficient in its own right, no longer measured in terms of anything else. Time remains as expressive of the interconnectedness of all events as p. 86 .

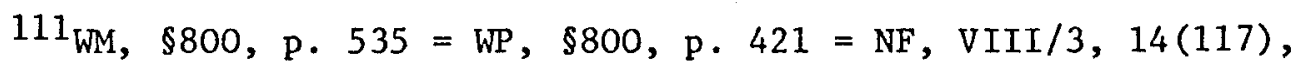

$112 \mathrm{FW}$, III, $\$ 233$, p. $170=\mathrm{JW}$, III, $\$ 233, \mathrm{p} .202 ; \mathrm{Z}$, III, "Der Genesende," 2 ; VI/I, p. 272 = Z, III, "The Convalescent," p. 220 .

$113_{Z}$, III, "Von alten und neuen Tafeln," 2 ; VI/1, p. $243=\mathrm{Z}$, III, "On the OId and New Tablets," 2, p. 197. 
organized by our will to power, but in giving up its function as a measure--imposed from outside--of those events, it is no longer experienced as an imposed measure. There is just a continual happening which we shape by our will to power.

Thus the first three aspects of the problem of time in Nietzsche's philosophy--the threat of the "it was," the tension between being and becoming, and the overcoming of traditional concepts of time--find their answer in his doctrine of the eternal recurrence of the same. 114 The fourth aspect, the demand for a creative affirmation of time, has also been confronted in the consideration of the modes of affirming the eternal recurrence, modes which have been shown to be reducible to the will to power. The new experience of time is the measure which our will to power creates: the eternal recurrence of the same. It now remains to consider, the relationship of this to the category of play.

D. Play and the Eternal Recurrence

The relationship between play and the eternal recurrence of the same has two basic aspects: the picture of the universe as a play of forces which is implicit (and sometimes explicit) in Nietzsche's descriptions of the universe, and the play character of the modes of affirming the eternal recurrence. The second aspect of this problem has already been explored in detail in the preceding chapter, where it was shown how thinking and willing were reducible in the end to the

${ }^{114}$ See above, especial1y pp. 219-20. 
interplay of affects, centers of force. In a similar manner, it was shown that the will to power on its most basic level was but the expression of this same interplay of forces. The modes of affirmation of the eternal recurrence are, when considered in regard to their most fundamental character, instances of the play of forces in which the individual is, properly speaking, both the player and the plaything of this world-play. The more powerful and active he is, the more will to power he has, the more he is a player. The weaker he is, the more he is a plaything.

In these concluding remarks on the eternal recurrence, I shal1 show that, if this doctrine is interpreted in terms of the category of play developed above, the unity and internal consistency of Nietzsche's view of man and the world becomes clear. The doctrine of the eternal recurrence does not mean, as Kaufmann erroneously claims, "that all events are repeated endlessly, that there is no plan [or] goal to give meaning to history or $1 \mathrm{ife}$, and indeed that we are mere puppets in an absolutely senseless play."115 Indeed, such a misinterpretation arises precisely out of a failure to understand the true nature of play as creative activity and the way in which play permeates Nietzsche's vision of existence. In play, plans and goals are continually created and then destroyed. If men are puppets, they can also pull some of the strings-and their ability to do so is a mark of their will to power. All events

${ }^{115}$ Walter Kaufmann, Nietzsche: Philosopher, Psychologist, Antichrist, p. 327. 
are repeated endlessly, but this repetition is itself characteristic of play. ${ }^{116}$ Moreover, as has been shown in the preceding analysis of the modes of affirming the eternal recurrence, it is a created recurrence, the full expression of the will to power. The compatibility of the will to power and the eternal recurrence becomes apparent when these are seen in relation to the category of play. The Play of the World: the Early Writings

The picture of the universe itself which is contained in the doctrine of the eternal recurrence of the same is best expressed in those two fragments which have been placed at the end of The Will to Power, but the theme itself was already present in Nietzsche's analysis of Heraclitus in his lectures on philosophy in the tragic age of the Greeks. Although this earliest description occurs as a description of Heraclitus's universe, it is clear from Nietzsche's remarks, both when writing "Philosophy in the Tragic Age of the Greeks,"117 and from a later remark in Ecce Homo ${ }^{118}$ that he is describing a view to which he is deeply sympathetic. ${ }^{119}$ The view itself has already been considered

117"Die Philosophie im tragischen Zeitalter der Griechen," in Nietzsche Werke, III/2, p. 329 = Philosophy in the Tragic Age of the Greeks, translated by Marianne Cowan (Chicago: Henry Regnery Company, 1962), p. 68. "Denn die Welt braucht ewig die Wahrheit, also braucht sie ewig Heraklit. . Das, was er schaute, die Lehre vom Gesetz im Werden und vom Spiel in der Nothwendigkeit, muß von jetzt ab ewig geschaut werden: er hat von diesem größten Schauspie1 den Vorhang aufgezogen."

$$
{ }^{118}{ }_{\mathrm{EH}}, " \mathrm{GT}, " 3 ; \mathrm{VI} / 3, \text { p. } 311=\mathrm{EH}, " \mathrm{BT}, " 3 \text {, pp. } 273-74 \text {. }
$$

${ }^{119}$ In addition to this evidence, there are the similarities between this description and the final two fragments of The Will to Power ( $\$ 1066,1067)$. 
above in relation to the will to power and play, ${ }^{120}$ but some aspects of the description given by Nietzsche are pertinent to the discussion of the world as play and the eternal recurrence.

First, the world itself is a game which the aeon plays with itse1f. Thus when one asks questions about the ultimate nature of the world and of existence--for example, why fire is not always fire, 121 or why voũs would impel a random material particle into a whirling dance around it ${ }^{122}$--one receives a clear answer: it is a 27 a game, play. Play is the final category of explanation, beyond which one cannot go, and the explanation it offers is this: that is the way things are; they have no significance except within this particular game, but insofar as we have been fellow-players, we have helped to create this game. The question "why" presupposes a meta-game within which the answer would be possible, but there is no such meta-game.

Second, the notion of the cosmos as play itself implies a notion of recurrence. Nietzsche's treatment of Heraclitus and Schopenhauer tend to merge into oneness at this point. 123 Not only is the notion of time as devouring its children present here, but also the idea that this ceaseless coming-to-be, the impermanence of everything actual, is

120 See above, Chapter Four.

121"Philosophie im tragischen Zeitalter der Griechen," 7; III/2, p. 326 = "Philosophy in Tragic Age of Greeks," p. 64.

$$
\begin{aligned}
& { }^{122} \text { Ibid., 19; III/2, p. } 363=i \text { bid., 19, p. } 112 . \\
& { }^{123} \text { Ibid., 5; III/2, p. } 317=i b i d ., 5, \text { p. } 52 .
\end{aligned}
$$


a terrible, paralyzing thought, ${ }^{124}$ a description strikingly similar to Zarathustra's descriptions of the eternal recurrence. The description of the play of the child and the aeon implies eternal recurrence: the continual creating of worlds, their destruction, then the starting anew with the creation of another world. Here the continual creating and destroying of worlds is what recurs, but it is not said that these worlds are all the same in the sense that their specific content is the same. They are, however, all the same in that they are all creations of the will to power. The Play of the World: the Final Vision

The final two fragments of The Will to Power develop in more detail Nietzsche's view of the world as play. 125 Fragment 1067, written in 1885, begins with the question: "And do you know what 'the world' is to me?"126 The Nietzschean world is a "monster of energy, without beginning, without end," its definite quantum of force confined to a finite space by the boundaries of nothingness. The space of this world

${ }^{124}$ Ibid., 5; III/2, p. $318=$ Ibid., 5, p. 54 .

${ }^{125}$ This analysis agrees with Eugen Fink's position (Nietzsches Philosophie, p. 106), when he writes: "Im Wissen von der Ewigen Wiederkunft läßt sich das Dasein ganz ein in das Spiel der Welt, wird zum Mitspieler des großen Spiels, die Trennung zwischen Notwendigkeit und Freiheit wird aufgehoben--und ähnlich, wie die Vergangenheit Zukunftscharaktere gewinnt und die Zukunft Vergangenehitscharaktere, so liegt jetzt in der Freiheit Notwendigkeit und in der Notwendigkeit Freiheit." The main difference between the two interpretations is that my position puts more emphasis on the importance of the player.

126 WM, \$1067, p. 696 = WP, \$1067, p. 549. "Und wißt ihr auch, was mir 'die Welt' ist?" 
is completely occupied by force:

-. as a play of forces and waves of forces, at the same time one and many, increasing here and at the same time decreasing there; a sea of forces flowing and rushing together, eternally changing, eternally flooding back, with tremendous years of recurrence, with an ebb and flood of its forms. 127

Just as Heraclitus' child creates regular worlds, which he then destroys, Nietzsche also creates order in his world, the order which is a play of contradictions and of concord:

- . out of the simplest forms striving toward the most complex, out of the stillest, most rigid, coldest forms toward the hottest, most turbulent, most self-contradictory, and then again returning home to the simple out of this abundance, out of the play of contradictions to the joy of concord, still affirming itself in this uniformity of its courses and its years, blessing itself as that which must return eternally, as a becoming that knows no satiety, no disgust, no weariness...128

This is the world which is the will to power and nothing more: the will

to power is the interplay of forces described here. The degree to which we become the will to power determines the degree to which we cease to be playthings and become players in the game of existence.

127 WM, $\$ 1067$, p. $697=\mathrm{WP}, \$ 1067$, p. 550. ". . . als Spiel von Kräften und Kraftwellen zugleich eins und vieles, hier sich häufend und zugleich dort sich mindernd, ein Meer in sich selber stürmender und flutender Kräfte, ewig sich wandelnd, ewig zurücklaufend, mit ungeheuren Jahren der Wiederkehr, mit einer Ebbe und Flut seiner Gestaltungen . . ."

128 Ibid. = ibid. ". . . aus den einfachsten in die vielfältigsten hinaustreibend, aus dem Sti11sten, Starrsten, Kältesten hinaus in das Glühendste, Wildeste, Sich-selber-Widersprechendste, und dann wieder aus der Fülle heimkehrend zum Einfachen, aus dem Spiel der Widersprüche zurück bis zur Lust des Einklangs, sich selber bejahend noch in dieser Gleichheit seiner Bahnen und Jahre, sich selber segnend als Das, was ewig wiederkommen muß, als ein Werden, das kein Sattwerden, keinen Überdruß, keine Müdigkeit kennt . . ." 
The same view of the world as play remained with Nietzsche until the end of his active life. In a fragment entitled "The New World-Conception," dating from the spring of 1888,129 Nietzsche again presents a picture of the world as a ceaseless coming-to-be and passingaway, without beginning or end, living on itself, its own excrements . But now he gives an argument for his conception of the universe which is directed against all those who would posit some final state for the world. In it the final meaning of the eternal recurrence of the same as play is presented, and the conditions of the possibility of such a world-view are enumerated: the world must be thought of as (1) a certain definite quantity of force, (2) with a certain definite number of centers of force, (3) existing in infinite time, and (4) finite space. 130 Given these conditions, the world, "in the great dice game of its existence," 131 must eventually repeat itself--must, in fact, repeat itself infinitely.

And since between every combination and its next recurrence all other possible combinations would have to have taken place, and each of these combinations conditions the entire sequence of

${ }^{129} \mathrm{WM}, \$ 1066$, pp. 694-96"WP, $\$ 1066$, pp. 548-49= NF, VIII/3, 14(188), pp. 166-68. The Colli and Montinari text contains a number of corrections, including the sub-title "Die ewige Wiederkunft. Philosophie" before the third paragraph. This is omitted in both the Kröner and Kaufmann editions.

130 This fourth necessary condition, finite space, is omitted in $\$ 1066$, but clearly indicated as necessary in $\$ 1067$.

${ }^{131}$ WM, $\$ 1066$, p. $696=$ WP, $\$ 1066$, p. $549=\mathrm{NF}, \operatorname{VIII} / 3,14(188)$, p. 168. ". . . im großen Würfelspiel ihres Daseins..." Kaufmann's translation omits "its" in this phrase, although the relative pronoun is to be found in both the Kröner and Colli and Montinari texts. 
combinations in the same series, a circular movement of absolutely identical series would thus be demonstrated: the world as a circular movement that has already repeated itself infinitely often and plays its game in infinitum. 132

The world in its most fundamental character is thus a game which, because of the finite number of pieces and its infinite duration, must eternally repeat itself.

We play along in this game of existence, following either of two paths. We may affirm existence as a game, as play, thereby realizing the created character of all order and meaning, and transforming the game as it is given to us by our own creative play. To do this is to become the free spirit, to overcome nihilism, to manifest one's will to power. The other possibility is that, instead of becoming players, we become playthings. We try to cover up the true character of existence by creating little games--systems of morality--which we then mistake for reality itself; but in doing so, we deny reality, the powerfulness of our passions and the like. This does not make them go away; they remain and continue to be powerful. We simply refuse to recognize them for what they are. This refusal makes us their playthings--and our little games are exercises in self-deception. Existence is indeed a game for both the strong and the weak, for the

132 Ibid. = ibid. = ibid. "Und da zwischen jeder 'Combination' und ihrer nächsten 'Wiederkehr' alle überhaupt noch möglichen Combinationen abgelaufen sein müßten und jede dieser Combinationen die ganze Folge der Combinationen in derselben Reihe bedingt, so wäre damit ein Kreislauf yon absolut identischen Reihen bewiesen: die Welt als Kreislauf der sich unendlich oft bereits wiederholt hat und der sein Spiel in infinitum spielt." The sentence is in the subjective mood, which Kaufmann's translation (e.g., "is thus demonstrated" instead of "would thus be demonstrated") seems to ignore. 
immoralists and the moralists, but the difference is that for the strong--the immoralists, the free spirits, the overman--it is a game that they play, while for the weak, the moralists and other "naysayers to life," it is a game in which they are but toys. 


\section{CONCLUSION}

Three main objectives have directed this inquiry. The first was that of discovering whether Nietzsche's philosophy was a phi1osophy of play. The second was to see if, by thinking through Nietzsche's philosophy in terms of play, it would be possible to make more sense out of his position than other commentators have done. The third and final objective was to think through the philosophy of play itself.

The first objective has been fulfilled. It has been established, not only in terms of textual evidence, but more importantly in terms of the meaning of his fundamental categories, that Nietzsche's philosophy was indeed a philosophy of play.

In the writings centering around The Birth of Tragedy, we have uncovered a five-fold meaning of the category of play: two types of Apollinian and Dionysian play respectively, and the tragic as the interplay of these two sets. Among the significant differences between Apollinian and Dionysian play was the one which centered around the role of the player: the Apollinian player was much more a player and in control of his game of illusions than his Dionysian counterpart. On the other hand, the Dionysian man was much closer to the truth of existence than the Apollinian player. When this opposition was raised from the natural to the artistic level, the types of play remained fundamentally the same, but the role of the player in both 
cases was strengthened. The Dionysian artist has an independent existence outside the flux of primordial existence. By reflecting that flux, he was able to confront and play with it and yet not destroy himself. The Apollinian artist, on the other hand, did not mirror this primordial contradiction, but rather sought to create a beautiful illusion to cover up the ugliness of existence. The notion of the tragic was that of a coming together of these irreconcilable worlds into a brief moment of synthesis, a synthesis to be understood as the interplay of these two worlds. This notion of play was seen, however, to be founded fundamentally in slavery: the slavery of the many provided the basis for the creative freedom of the few.

The notion of play found in Nietzsche's later philosophy is a development of that view already presented in the writings on the Greeks, but the differences are highly significant. There are two basic types of play in Nietzsche's mature thought--although the word "types" is misleading here. It is more precise to say that there is an order of rank in play. The lowest rank is formless, chaotic play: the interplay of forces in the cosmos. However, qualification is again needed. It is a formless play of forces for those who lack the power to create something more out of it. The highest place in this order of rank is occupied by the powerful, creative play which gives order, form, meaning and value to the world. This is the play which, in Chapter Three, was seen as characteristic of the child, the free (fs)irit, and those highest in the order of rank. In Chapter Five it was shown that this was the proper activity of the overman, a 
category which unifies the previously developed images of the child, free spirit and highest in the order of rank.

This order of rank of play also provided an order of rank of players, stretching from the least powerful to the strongest. The least powerful were only minimally players, since they were least in control of the games that they played. They are more adequately described as playthings than players. The most powerful ones, epitomized by the overman, were players in the fullest sense: not only were they in control of the games they were playing, they were also the very creators of those games.

These are not two separate orders of rank, one of which refers to play in itself, the other of which refers to players. Rather, there is only one order of rank of play: that which is founded in the player. Formless, chaotic play is a mark of the interpreter's lack of power. The stronger the will to power, the more the player will impose his own order on that which, for the weaker ones, is chaos.

This interpretation brings together the central themes in Nietzsche's position and shows the fundamental harmony among them. The overman is the player par excellence, the notion of the will to power expresses the nature of his activity as creative play, and the doctrine of the etenal recurrence of the same expresses the fundamental nature of the game which he creates out of the lawless interplay of forces in the cosmos. Nietzsche's critique of morality and the lower orders of rank flows from the order of rank of play: the lower ranks are examples of less powerful playing, weaker instances of the will to power. While the overman affirms all of existence in his creative play, he 
does so creatively. This involves, among other things, making a new order of rank in which the lower ranks are recognized for what they are: less powerful instances of the will to power, often declining instances of it. The notions of the eternal recurrence of the same, the will to power and the overman are in fundamental harmony--and the basis of that harmony is the category of play. Moreover, there is no contradiction between Nietzsche's critical philosophy and his own positive position. The basis of his criticisms is clear: he contrasts less powerful, less creative play to the more powerful, creative play of the overman's will to power. He criticizes the weaker forms of play precisely because they are weaker and because they do not lead to more powerful forms of play.

This position represents a development which goes beyond the position presented in the writings from the period of The Birth of Tragedy. The overman is in control of his play in a way similar to the Apollinian player, but he is also able to recognize the insights of the Dionysian man into the chaotic character of primordial existence. However, he goes beyond both by realizing that primordial existence is chaotic only because of the absence of a creative will to power which gives form, meaning and value. There is no existence "in itself" which is chaotic--there are, in the end, only interpretations which are distinguished according to power.

In this view of play, there need be no difference between work and play. Play creates worlds, as does work. The activity of the overman is in this sense a synthesis of work and play. However, a distinction can be drawn between work and play in another sense. What 
most people commonly regard as work is less powerful, less free, a weaker form of play: it is a plodding, weary, coerced participation in creating a world.

Thus Nietzsche's mature philosophy of play goes beyond that developed in his early writings on the Greeks and overcomes the tensions between the Apollinian and the Dionysian worldviews and between work and play.

The first two objectives of this study have thus been achieved. Nietzsche's philosophy is one of play and in its mature form a consistent one, overcoming the tensions in his earlier position and not subject to the contradicitions some of his critics have claimed to find there.

The third objective, however, has only been partially achieved. While a philosophy of play has been developed, the philosophy of play certainly has not been exhausted. There are other ways in which it can be done, and I am not yet satisfied that Nietzsche's way of developing a philosophy of play is the best. The reservations that $I$ have in regard to Nietzsche's position have already been stated in Chapter One, and it would serve no purpose to repeat them here. To develop them fully would require another volume--hardly the thing to begin in a conclusion. 


\section{BIBLIOGRAP HY}

Texts and Transzations of Nietzsche's Works

A. The Kritische Gesamtausgabe of Nietzsche's Works

Wherever possible, references to the German text of Nietzsche's works have been to the Kritische Gesamtausgabe of the Nietzsche Werke, edited by Giorgio Colli and Mazzino Montinari. Since this edition is not yet complete, other editions also had to be used. These are listed in the next section of the bibliography. The part (Abteilung) and volume (Band) numbers of the volumes in the Kritische Gescomtausgabe are given at the left of the entry. A11 volumes have been edited by Giorgio Co11i and Mazzino Montinari.

III/1 Die Geburt der Tragödie. Unzeitgemässe Betrachtungen I-III (1872-74). Berlin: Walter de Gruyter Verlag, 1972.

III/2 Nachgelassene Schriften. 1870-1873. Berlin: Walter de Gruyter Verlag, 1973.

IV/1 Richard Wagner in Bayreuth. Nachgelassene Fragmente, 1875-1876. Berlin: Walter de Gruyter Verlag, 1967.

IV/2 Menschliches, Allzumenschliches I. Nachgelassene Fragmente, 1876 bis Winter 1877-1878. Berlin: Walter de Gruyter Verlag, 1967.

IV/3 Menschliches, Allzumenschliches II. Nachgelassene Fragmente, Fruhling 1878 bis November 1879. Berlin: Walter de Gruyter Verlag, 1.967.

IV/4 Mazzino Montinari, Nachbericht zur vierten Abteilung: Richard Wagner in Bayreuth; Menschliches, Allzumenschliches I u. II; Nachgelassene Fragmente (1875-1879). Berlin: Walter de Gruyter Verlag, 1969.

V/1 Morgenröthe. Nachgelassene Fragmente, Anfang 1880 bis Frühjahr 1881. Berlin: Walter de Gruyter Verlag, 1971. 
VI/1 Also sprach Zarathustra, Ein Buch für Alze und Keinen. Berlin: Walter de Gruyter Verlag, 1968.

VI/2 Jenseits von Gut und Böse, Zur Genealogie der Moral, Berlin: Walter de Gruyter Verlag, 1968.

VI/3 Der Fall Wagner. Götzen-Dömmerung. Nachgelassene Schriften (August 1888-Anfang Januar 1889): Der Antichrist; Ecce Homo; Dionysos-Dithyramben. Nietzsche contra Wagner. Berlin: Walter de Gruyter Verlag, 1970.

VIII/2 Nachgelassene Fragmente, Herbst 1887 bis März 1888. Berlin: Walter de Gruyter Verlag, 1970.

VIII/3 Nachgelassene Fragmente, Anfang 1888 bis Anfang Januar 1889. Berlin: Walter de Gruyter Verlag, 1972.

B. Other German Editions Cited

Nietzsche, Friedrich. Nachgelassene Werke aus den Jahren 18691872. Nietzsche's Werke. Volume IX. Leipzig: C. G. Naumann, 1903. - Die Geburt der Tragödie. Der griechische Staat. Afterword by Alfred Baeumler. Kröner Taschenausgabe Band 70. Stuttgart: Alfred Kröner Verlag, 1964.

- Die fröhliche Wissenschaft. Afterword by Alfred Baeumler. Kröner Taschenausgabe Band 74. Stuttgart: Alfred Kröner Verlag, 1965.

- Der Wizle zur Macht. Selected and ordered by Peter Gast with the aid of Elisabeth Förster-Nietzsche. Afterword by Alfred Baeumler. Kröner Taschenausgabe Band 78. Stuttgart: Alfred Kröner Verlag, 1964.

- Die Unschuzd des Werdens. Der Nachlass, Selected and orde $\overline{r e d ~ b y ~ A l f r e d ~ B a e u m l e r . ~ K r o ̈ n e r ~ T a s c h e n a u s g a b e, ~ B a ̈ n d e ~} 82$ and 83. Two volumes. Stuttgart: Alfred Kröner Verlag, 1956.

C. English Translations Cited

The previous entries have been listed chronologically according to their original date of publication. Since the volumes of English translations at times contain separate books originally published at different times, they will simply be listed alphabetically according to title. 
Nietzsche, Friedrich. Beyond Good and Evil, Prelude to a Phizosophy of the Future. Translated, with Commentary by Walter Kaufmann. Vintage Books, New York: Random House, 1966.

- The Birth of Tragedy. The Case of Wagner. Translated, with Commentary by Walter Kaufmann. Vintage Books. New York: Random House, 1967.

- On the Genealogy of Morals. Ecce Homo. Translated by Walter Kaufmann and R. J. Hollingdale. Edited, with Commentary, by Walter Kaufmann. Vintage Books. New York: Random House, 1967.

- The Joyful Wisdom. Translated by Thomas Common. Poetry versions by Paul V. Cohn and Maude D. Petre. Introduction by Kurt F. Reinhardt. New York: Frederick Ungar Publishing Company, 1968.

- Philosophy in the Tragic Age of the Greeks. Translated, with an Introduction by Marianne Cowan. A Gateway Edition. Chicago: Henry Regnery Company, 1962.

- The Portable Nietzsche. Selected and translated, with an Introduction, Prefaces, and Notes by Walter Kaufmann. New York: The Viking Press, 1968. [Translations of Twilight of the Idols, The Antichrist, and Nietzsche contra Wagner are cited according to this edition.]

- Thus Spoke Zarathustra. Translated, with a Preface by Walter Kaufmann. Compass Books Edition. New York: The Viking Press, 1966.

- The Wizl to Power. Translated by Walter Kaufmann

and R. J. Hollingdale. Edited, with Commentary by Walter Kaufmann. New York: Random House, 1967.

Secondary Literature

The following lists include works either cited or consulted in the preparation of this dissertation. The first section is composed of works dealing directly with Nietzsche. The second section is devoted to works not directly related to Nietzsche, but dealing with topics discussed in this dissertation, especially with the philosophy of play. In neither case is the bibliography to be taken as an exhaustive list of works dealing with the topics under consideration. 
Assaad-Mikhail, Fawzia. "Jaspers interprète de Nietzsche." Revue de Métaphysique et de Morale, 70 (1966), 307-38.

Birault, Henri. "En quoi, nous aussi, nous sommes encore pieus." Revue de Métaphysique et de Morale, 67 (1962), 25-64.

Bröcker, Werner. "Nietzsches Narrentum." Nietzsche-Studien, I (1972), 138-46.

Capek, Milic. "The Theory of the Eternal Recurrence." Joumal of Phizosophy, LVII (1960), 289-96.

Danto, Arthur. "The Eternal Recurrence." Nietzsche. A Collection of Critical Essays. Edited by Robert Solomon. Modern Studies in Philosophy. Garden City, New York: Anchor Press/Doubleday, 1973.

Company, 1965. Nietzsche as PhiZosopher. New York: The Macmillan

Deleuze, Giles. Nietzsche et la philosophie. Bibliothèque de philosophie contemporaine. Paris: Presses Universitaires de France, 1962.

Driscoll, Giles. "Nietzsche and Eternal Recurrence." The Personalist, 47 (March-Apri1, 1966), 461-74.

Enge1, S. M. "An Early Nietzsche Fragment on Language." Journal of the History of Ideas, 24 (1963), 279-86.

Fink, Eugen. Nietzsches PhiZosophie. Urban Bücher. Die Wissenschaftiche Taschenbuchreihe 45. Stuttgart: Kohlhammer, 1968.

Frings, Manfred F. "Nietzsche, by Martin Heidegger." Joumal of Phizosophy, 59 (1962), 830-35.

Fruchon, Pierre. "Note sur 1'idée de création dans la dernière pensée de Nietzsche." Edudes phiZosophiques, 17 (1962), 487-92.

Granier, Jean. La problème de la vérité dans la phizosophie de Nietasche. L'ordre philosophique. Paris: Editions du Seui1, 1966.

Gray, J. Glenn. "Heidegger 'Evaluates' Nietzsche." Joumal of the History of Ideas, 14 (1953), 304-09.

Heftrich, Eckhard. Nietzsches Philosophie. Identität von Welt und Nichts. Frankfurt am Main: Vittorio Klostermann, 1962. Neske, 1961 .

Heidegger, Martin. Nietzsche. Two volumes. Pfullingen: 
furt am Main: Vittorio Klostermann, 1950. "Nietzsches Wort 'Gott ist tot'." Holawege. Frank- What Is Called Thinking? Translated by Fred D. Wieck and J. Glenn Gray. Introduction by J. Glenn Gray. Religious Perspectives, Volume XXI. New York: Harper and Row, 1968.

sätze. Pfullingen: "Wer ist Nietzsches Zarathustra?" Vorträge und AufPfullingen: Neske, 1967.

Heidemann, Ingeborg. Der Begriff des Spieles und das ästhetische Weltbild in der Philosophie der Gegerwart. Berlin: Walter de Gruyter, 1968.

$53(1961-62), 507-44$.

"Nietzsches Kritik der Metaphysik." Kant-Studien, I (1972), 95-137. "Nietzsches Kritik der Moral." Nietzsche-Studien,

Heimsoeth, Heinz. "Des jungen Nietzsche Weg zur Philosophie." Studien zur Philosophiegeschichte. Cologne: Kölner Universitäts-Verlag, 1961.

. "Zur Anthropologie Friedrich Nietzsches." Studien zur Philosophiegeschichte. Cologne: Kölner Universitäts-Verlag, 1961.

Jaspers, Kar1. Nietzsche. An Introduction to the Understanding of his Philosophical Activity. Translated by Charles Wallraff and Frederick J. Schmitz. Tuscon: University of Arizona Press, 1965.

Kaufmann, Walter. Nietzsche: Philosopher, Psychologist, Antichrist. Third edition, revised and enlarged. Vintage Books. New York: Random House, 1968.

Königson, M.-J. M. "Nietzsche et la philosophie." Etudes phizosophique, 21 (1966), 61-79.

Löwith, Karl. From Hegel to Nietzsche. The Revolution in Nineteenth-century Thought. Translated by David E. Green. New York: Holt, Rinehart and Winston, 1964.

- Nietzsches Philosophie der ewigen Wiederkehr des Gleichen. Neue Ausgabe. Stuttgart: Kohlhammer, 1956.

Marietti, Angèle $\mathrm{K}$. "Nietzsche et la vérité." Revue de métaphysique et de morale, 71 (1967), 486-96.

Morgan, George A. What Nietzsche Means. Harper Torchbooks. New York: Harper and Row, 1965. 
Müller-Lauter, Wolfgang. Nietzsche. Seine Philosophie der Gegensätze und die Gegensätze seiner Philosophie. Berlin: Walter de Gruyter Ver1ag, 1971.

Okochi, Roger. "Nietzsches Amor Fati im Lichte vom Karma des Buddhismus." Nietzsche-Studien, I (1972), 36-94.

Paumen, Jean. "La pensée nietzschéene du dépassement." Revue internationale de la philosophie, 18 (1964), 119-37.

Pfeffer, Rose. "Eternal Recurrence in Nietzsche's Philosophy." Revue of Metaphysics, 19 (1965), 276-300.

The Personalist, 48 (1967), 5-24.

Reichert, Herbert W., and Schlechta, Kar1. Intermational Nietzsche Bibliography. University of North Carolina Studies in Comparative Literature. Number Forty-Five. Revised and expanded. Chape1 Hi11: University of North Carolina Press, 1968.

Rogers, Robert. "The Moral Philosophy of Nietzsche." The Personalist, 46 (1965), 18-38.

Rosen, Stanley. Nihilism. A Philosophical Essay. New Haven: Yale University Press, 1969.

Schlechta, Kari, and Anders, Anni. Friedrich Nietzsche. Von den verborgenen Anfängen seines Philosophierens. Stuttgart: Bad Cannstatt: Friedrich Frommann Verlag, 1962.

Simmel, Georg. Schopenhauer und Nietzsche: Ein Vortragsayklus. Leipzig: Duncker und Humblot, 1907.

Sol1, Ivan. "Reflections on Recurrence: A Re-examination of Nietzsche's Doctrine, die Ewige Wiederkehr des Gieichen." Nietzsche. A Collection of Critical Essays. Edited by Robert Solomon. Modern Studies in Philosophy. Garden City, New York: Anchor Press/Doubleday, 1973.

Stambaugh, Joan. "Das Gleiche in Nietzsches Gedanken der ewigen Wiederkunft des Gleichen." Revue internationale de philosophie, 18 (1964), 91-118.

The Hague: Martinus Nijhoff, 1959.

Stern, Alfred. "Nietzsche et le doute méthodologique en morale." Revue de philosophie de la France et de Z'étranger, 139 (1949), 48-59. 
Wah1, Jean. "Le Nietzsche de Fink." Revue de métaphysique et de morale, 67 (1962), 475-89.

- "Le problème du temps chez Nietzsche, commentaire du livre de Joan Stambaugh." Revue de métaphysique et de morale, 66 (1961), 436-56.

Wein, Hermann. "Métaphysique et Anti-métaphysique: accompagné de quelques réflexions pour la défense de l'oeuvre de Nietzsche." Revue de métaphysique et de morale, 63 (1958), 385-411.

Zuboff, Arnold. "Nietzsche and Eternal Recurrence." Nietzsche. A Collection of Critical Essays. Edited by Robert Solomon. Modern Studies in Philosophy. Garden City, New York: Anchor Press/Doubleday, 1973.

Other Works Cited or Consulted

Axelos, Kostas. Le jeu du monde. Arguments 41. Paris: Les Editions de Minuit, 1969.

Bally, Gustav. Vom Spielraum der Freiheit. Die Bedeutung des Spiels bei Tier und Mensch. Basel/Stuttgart: Schwabe \& Co., 1966.

Fink, Eugen. Oase des Glücks. Gedanken zu einer Ontologie des Spiels. Munich: Karl Alber Verlag, 1957.

1960.

- Spiel als Weltsymbol. Stuttgart: Kohlhammer,

Huizinga, Johan. Homo Ludens. A Study of the Play-EZement in culture. Boston: Beacon Press, 1955.

Lorenz, Konrad. On Aggression. Translated by Marjorie Kerr Wilson. Bantam Books. New York: Harcourt, Brace \& World, 1967.

Marx, Kar1. "Ökonomisch-philosophische Manuskripte (1844)." Werke. Supplementary Volume, Part One. Berlin: Dietz Verlag, 1968.

, and Engels, Friedrich. Die deutsche Ideologie.

Werke. Volume III. Berlin: Dietz Verlag, 1969.

Moltmann, Jürgen. Theology of Play. Translated by Reinhard Ultich. New York: Harper and Row, 1972.

Neale, Robert E. In Praise of Play. Toward a Psychology of Religion. New York: Harper and Row, 1969.

Novak, Michael. The Experience of Nothingness. Harper Colophon Books. New York: Harper and Row, 1971. 
Plessner, Helmuth. "Spiel und Sport." Diesseits der Utopie. Ausgewählte Beiträge zur Kultursoziologie. Düsseldorf/Cologne: Eugen Diederichs Verlag, 1966.

Rahner, Hugo. Der spielende Mensch. Christ Heute. Zweite Reihe. Achtes Bändchen. Einsiedeln: Johannes Verlag, 1952.

Rigauer, Bero. Sport und Arbeit. Soziologische Zusammenhänge und ideologische Implikationen. Frankfurt am Main: Suhrkamp Verlag, 1969 .

Schiller, Friedrich. On the Aesthetic Education of Man in a Series of Letters. Translated with an Introduction by Reginald Sne11. New York: Frederick Ungar, 1965.

Thielicke, Helmuth. Nihilism. Its Origin and Nature--with a Christian Answer. Translated by John W. Doberstein. Introduction by Michael Novak. New York: Harper and Row, 1961.

Work in America. Report of a Special Task Force to the Secretary of Health, Education and Welfare. Cambridge: The MIT Press, n.d. 


\section{APPENDIX \\ LIST OF ABBREVIATIONS}

The following abbreviations have been used when referring to Nietzsche's works. Where both the German and the English editions have been cited, both abbreviations are given. The German is given first, followed by the English. Where only one abbreviation appears, only the German text has been cited. Full bibliographical information about the editions cited in given in the Bibliography.
$A=A$
Der Antichrist $=$ The Antichrist
$\mathrm{EH}=\mathrm{EH} \quad$ Ecce Homo $=$ Ecce Homo
$\mathrm{FW}=\mathrm{JW} \quad$ Die fröhliche Wissenschaft $=$ The Joyful Wisdom
$\mathrm{GD}=\mathrm{TI} \quad$ Die Götzen-Dämmerung = The Twilight of the Idols
$\mathrm{GM}=\mathrm{GM} \quad$ Zur Genealogie der Moral = On the Genealogy of Morals
$\mathrm{GT}=\mathrm{BT} \quad$ Die Geburt der Tragödie = The Birth of Tragedy
$\mathrm{JGB}=\mathrm{BGE}$ Jenseits von Gut und Böse = Beyond Good and Evil
Morgenröthe
MA Menschliches, Allzumenschliches
NF Nachgelassene Fragmente
UB Unzeitgemässe Betrachtungen
$\mathrm{WM}=\mathrm{WP} \quad$ Der Wille zur Macht $=$ The Will to Power
$\mathrm{Z}=\mathrm{Z} \quad$ Also sprach Zarathustra = Thus Spoke Zarathustra 
The dissertation submitted by Lawrence Michael Hinman has been read and approved by the following Committee:

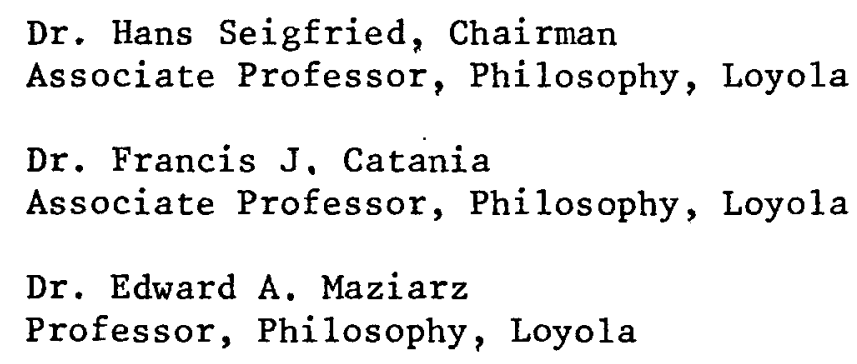

The final copies have been examined by the director of the dissertar. tion and the signature which appears below verifies the fact that any necessary changes have been incorporated and that the dissertation is now given final approval by the Committee with reference to content and form.

The dissertation is therefore accepted in partial fulfillment of the requirements for the degree of Doctor of Philosophy.
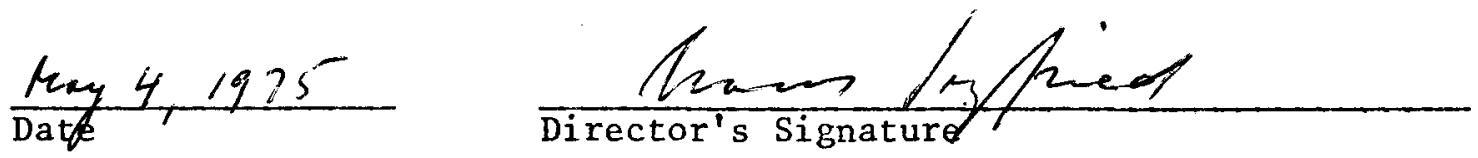